FÁBIO FERRAZ MARQUES

\title{
A PRESTAÇÃO PRIVADA DE SERVIÇOS PÚBLICOS NO BRASIL
}

\author{
MESTRADO EM DIREITO
}

ORIENTADOR: PROFESSOR DOUTOR EDMIR NETTO DE ARAÚJO

FACULDADE DE DIREITO DA UNIVERSIDADE DE SÃO PAULO

$$
\text { SÃO PAULO - } 2009
$$


FÁBIO FERRAZ MARQUES

\section{A PRESTAÇÃO PRIVADA DE SERVIÇOS PÚBLICOS NO BRASIL}

Dissertação apresentada à Banca Examinadora da Faculdade de Direito da Universidade de São Paulo, como exigência parcial para obtenção do título de Mestre em Direito, sob a orientação do Professor Doutor Edmir Netto de Araújo.

\section{SÃO PAULO}


BANCA EXAMINADORA 
A Helena, Ana, Gustavo e Fernanda 


\section{AGRADECIMENTO}

Ao Professor Edmir Netto de Araújo, pela a honra de ter-me aceitado entre os seus orientandos, por sua compreensão, generosidade e, sobretudo, paciência. 


\section{RESUMO}

MARQUES, Fábio Ferraz. A prestação privada de serviços públicos no Brasil. 2009. 143 p. Dissertação (Mestrado em Direito) - Faculdade de Direito da Universidade de São Paulo, São Paulo, 2009.

A prestação privada de serviços públicos constitui atividade essencial do Estado contemporâneo. $\mathrm{O}$ objeto deste trabalho é o exame das formas de prestação privada de serviços públicos no Brasil. De início, analisa como pressuposto para o desenvolvimento do tema central a atividade administrativa estatal prestada nos três níveis da Federação (União, Estados, Distrito Federal e Municípios), na qual se insere a atividade administrativa material de prestação de serviço público. A seguir, analisa a evolução e as motivações da passagem da execução do serviço público, de início apenas feita pelo próprio Poder Público, para os particulares. O exame dos fundamentos constitucionais do serviço público, plantados na Constituição de 1988, aplicáveis aos três níveis de poder federativo e o estudo das formas de delegação de serviço público aos particulares previstas nos artigos 175, 223 e nos incisos XI e XII do artigo 21 da Constituição Federal completam a análise. O tema central do estudo é tratado em seguida, que cuida especificamente das formas de serviço público que permitem sua prestação por particulares e que são admitidas no ordenamento jurídico brasileiro. Demonstrado que a delegação de serviços públicos para a iniciativa privada, consoante determina a Constituição de 1988, se realiza sob três formas, a concessão, a permissão e a autorização, o trabalho se debruça inicialmente no exame da concessão de serviços públicos rotulada de tradicional. Por se tratar da primeira das fórmulas de execução privada de serviços públicos, detém-se o texto no estudo dos vários aspectos que envolvem essa modalidade de prestação de serviços públicos, aspectos que vão servir de parâmetro para a análise das demais espécies de delegação de serviços públicos aos particulares. Assim, após um breve histórico dos antecedentes da concessão de serviços públicos, examina, além de outros pontos, o significado da expressão e sua natureza jurídica, a exigibilidade de licitação e as formas de extinção da relação decorrente da concessão. As características da concessão são desenvolvidas sob a ótica tríplice do que se denomina de "participantes" ou "atores" na relação de concessão: a Administração Pública, o concessionário e o usuário e, a partir delas, busca extrair uma conceituação da concessão de serviços públicos adequada aos objetivos do trabalho. Nesse tópico, ponto relevante do tema é o que diz respeito ao exame das espécies de concessão admitidas pela doutrina e pelo ordenamento jurídico brasileiro: a concessão patrocinada, ou as parcerias público-privadas e a concessão administrativa, os consórcios público-privados e a franquia. As outras modalidades constitucionais de delegação de serviços públicos, a permissão e a autorização, constituem tema de estudo dos tópicos seguintes. Considera na análise dessas modalidades, particularmente no que diz respeito à autorização, a problemática apontada pela doutrina contemporânea quanto à sua inserção, dentre as formas de delegação de serviços públicos e a sua efetiva aplicabilidade na estrutura administrativa dos três níveis da Federação brasileira.

Palavras-chaves: Serviço público - Delegação de serviço público - Serviço público exercido por particulares - Concessão de serviço público - Concessão patrocinada - Concessão administrativa - Parcerias público-privadas - Franquia - Permissão de serviço público - Autorização de serviço público. 


\begin{abstract}
MARQUES, Fábio Ferraz. The public services provided by the private sector in Brasil. 2009. 143 p. Dissertation (Master Degree in Law) - Faculdade de Direito da Universidade de São Paulo, São Paulo, 2009.

Providing public services is an essential duty of the modern state. The purpose of this study is to analyse the manners in which the private sector in Brazil provide public services. First it analyses as a precondition to develop the central theme, the state's administrative activities throughout Brazil's three constitutional levels (the union, states, federal district and the cities) in which the public services are provided. Then it analyses how public services have developed since they were first offered by the State, to their transformation in being offered by the private sector. There then follows a study of articles 175, 223 and 21(XI) and (XII) of Brazil's Constitution of 1988, which provide the grounds for the offering of public services throughout the levels of the federation. It closes with a study of how public services are delegated to the private sector. After it analyses the central theme of this study; the different types of public services that Brazilian law states may be delegated to the private sector. The study explains that under the 1988 Constitution, public services may be delegated to the private sector using three different forms: concessions; permissions, and authorisations. The text first examines the traditional method of delegating public service: the granting of concessions. The study then analyses the different forms of concession, which will act as a parameter for the other types of delegation. After a brief history of public service concessions, the study examines the legal meaning of "concession" under Brazilian law, the need for a public tender and how concessions are terminated. The characteristics of the concession are developed using three perspectives from what are called "participants" or "actors" in the concession relationship: the government, the concessionaire and the user of the services. The study then attempts to define a concept of a public services concession that ties in with the purposes of this study. In this context, the study then considers legal scholarship and the Brazilian legal system: sponsored concessions, or the public-private partnership (PPPs) the administrative concessions, the public-private joint venture and franchises. The study progresses to an analysis of the other types of delegated public services - the permissions and authorisations. In analysing these types of delegation - and especially the authorisation the problem arising from modern legal scholarship is considered in the context of its relation with the other types of delegations of public services, and how it actually applies throughout the three constitutional levels.
\end{abstract}

Key-words: Public services - Delegation of public services - Public services provided by the private sector - Public service concessions - Sponsored concessions Administrative concessions - Public-private partnerships - Franchises - Public services licenses - Public services authorisation. 


\section{SUMÁRIO}

INTRODUÇÃO

1 A ATIVIDADE ADMINISTRATIVA ESTATAL

2 SERVIÇO PÚBLICO EXERCIDO POR PARTICULARES

2.1 Serviço público: da execução do serviço pelo Poder Público à possibilidade

da execução privada 19

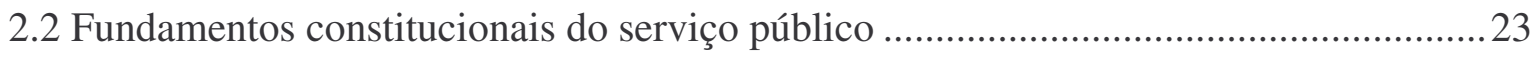

2.3 As formas de delegação do serviço público no direito brasileiro

3.1 Concessão de serviços públicos 39

3.1.1 A concessão tradicional 39

3.1.1.1 Antecedentes. 39

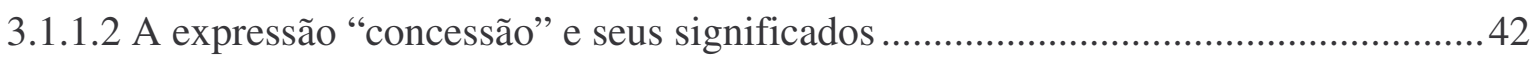

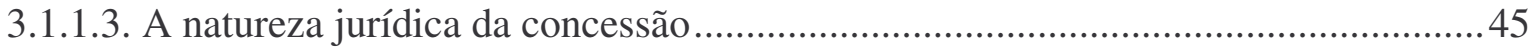

3.1.1.4 A concessão de serviço público e o contrato de locação de serviços ........................50

3.1.1.5 Características e conceito de concessão de serviço público 53

3.1.1.5.1 Concessão de serviço público e presença da Administração Pública como contratante: poderes exorbitantes.

3.1.1.5.2 Características da concessão, sob a ótica de serem os serviços executados por pessoa jurídica de direito privado 66

3.1.1.5.3 A concessão e os usuários do serviço público 71

3.1.1.5.4 Conceituação de concessão de serviço público ..................................................... 80

3.1.1.6 Remuneração do concessionário 82

3.1.1.7 Subcontratação, subconcessão, transferência da concessão e transferência do controle acionário

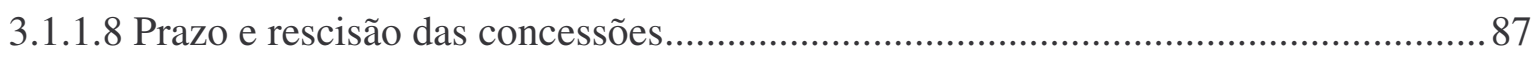

3.1.1.9 A licitação nas concessões de serviço público........................................................90

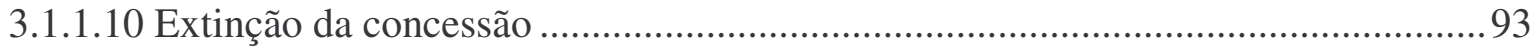

3.1.2 Concessão patrocinada e concessão administrativa ....................................................94 
3.1.2.1 Remissão à Lei 8.987/95.

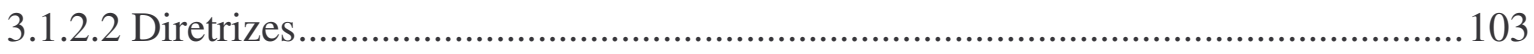

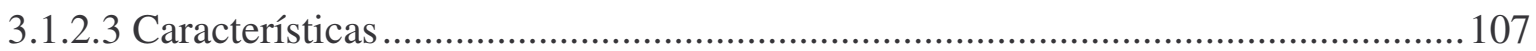

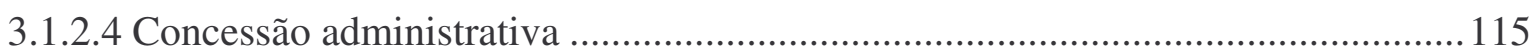

3.1.3 Franquia como modalidade de concessão............................................................ 119

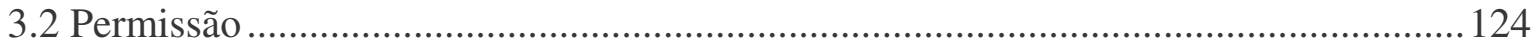

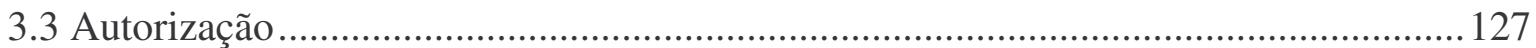

3.3.1 A autorização como forma de delegação de serviço público...................................127

3.3.2 A autorização e a Lei Geral de Telecomunicações.................................................... 130

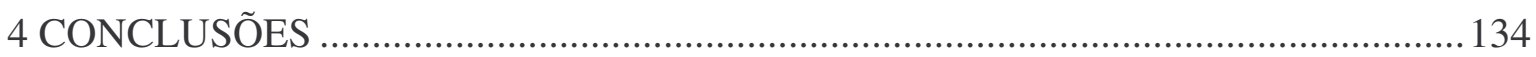

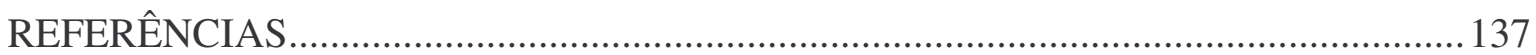




\section{INTRODUÇÃO}

Esta dissertação circunscreve-se ao exame dos serviços públicos conceituados como serviços públicos em sentido restrito, e que constituem uma atividade material estatal prestada aos usuários sob regime de direito público.

Assim circunscrito o tema, serão tratados neste trabalho os serviços públicos delegados a particulares, tal qual estabelece o regramento constitucional pátrio, isto é, através das modalidades de concessão, permissão e autorização.

A prestação privada de serviços públicos está inserida no contexto da Administração Pública do Brasil deste século XXI. Surge como resultado do ideal de diminuição do tamanho do Estado, verificada a partir da década de 80 do século passado.

Nesse quartel do século XX, os serviços públicos eram, como regra geral, prestados pelo Estado diretamente, mas não supriam as necessidades dos usuários, vale dizer, da comunidade em geral.

De um lado, havia o Estado que não se desincumbia de suas tarefas de forma satisfatória, e, de outro, o usuário do serviço que não era atendido em suas necessidades, mesmo básicas, pelo Poder Público.

A reintrodução da delegação da execução dos serviços aos particulares como uma das formas para a solução desta questão deu novamente força aos institutos da concessão, da permissão e da autorização, que são abordados no trabalho. Estes institutos mostraramse, em sua adoção contemporânea, constituir úteis instrumentos para a concretização da idéia de privatização dos serviços públicos de modo mais adequado ao interesse público e à sociedade.

Fundamenta a opção pela adoção de referidos institutos a idéia geral de que o particular, mais ágil e com foco na atividade que lhe é delegada, tem possibilidades maiores de se desincumbir da prestação dos serviços públicos com maior eficiência e melhores resultados, do ponto de vista particularmente dos usuários. 
Nesta nova etapa de delegação de serviços públicos, todavia, alguns pontos devem ser levados em consideração: o direito subjetivo do usuário de receber a prestação de serviços de qualidade, eficientes, pagando tarifas módicas, acumulado ao ideal de sua participação cada vez mais ativa nesta relação de delegação de serviços, em linha com os novos direitos previstos na Constituição Federal de 1988.

A Constituição de 1988, alargando o conceito de cidadania e atribuindo ênfase especial ao tratamento dos direitos e garantias fundamentais, como forma de assegurar a meta fundamental do Estado que é a realização do interesse público, abre importantes espaços para a participação do cidadão nas atividades de controle e fiscalização do poder, participação esta que vai além do simples exercício dos direitos políticos ativos, ou direito de voto, usualmente consagrados em nossos textos constitucionais.

Ante tudo isto, o tema prestação de serviços públicos pelos particulares adquire nova realidade e inegável atualidade perante a Constituição de 1988, merecendo profundo exame pela doutrina e especial tratamento jurisprudencial.

Estas as razões que motivaram a análise desse tema.

Assim, neste trabalho, para o desenvolvimento da matéria, se adotará o seguinte plano: após um exame introdutório, vertido nos Capítulo I, onde se analisam as atividades administrativas do Estado, matéria necessária para a colocação do tema objeto da análise, se passa para o Capítulo II, que tem por objeto o exame do serviço público prestado por particulares, sob três aspectos: da execução pública à execução privada dos serviços públicos; os fundamentos constitucionais do serviço público no Brasil e as formas de delegação do serviço público admitidas no direito brasileiro. O Capítulo III - central no trabalho - cuida das formas de prestação de serviços públicos pelos particulares, no ordenamento pátrio. Assim, será objeto de análise a concessão de serviços públicos.

Além da chamada concessão tradicional, o trabalho também examina as espécies de concessão, admitidas pela doutrina com base no ordenamento jurídico pátrio, e que são: a concessão patrocinada, a concessão administrativa, também denominada parceria públicoprivada, e a franquia, e das demais modalidades de delegação de serviços públicos 
expressamente previstas na Constituição, ou seja, a permissão e a autorização. Ao final se busca extrair algumas conclusões provocadas pelo exame do tema ao longo do trabalho.

É claro que este trabalho não tem a pretensão de esgotar o assunto, que, por sua natureza envolve um sem número de vertentes apontadas pela doutrina.

Procurou-se, tão somente, sistematizar os aspectos mais relevantes do tema, nas perspectivas indicadas, a partir de vasta fonte doutrinária, como modesta contribuição para seus estudos, dada a relevância atual dessa modalidade de prestação de serviços públicos no Brasil. 


\section{A ATIVIDADE ADMINISTRATIVA ESTATAL}

Considera-se o serviço público um dos tipos de atividade estatal. Pretende-se neste capítulo demonstrar a inserção do serviço público no rol das atividades administrativas do Estado, dentro do qual se encontra o serviço público prestado por particulares, tema deste trabalho.

Há várias formas de analisar as atividades do Estado. Sob uma perspectiva mais ampla, as atividades desenvolvidas pelo Estado podem ser divididas opondo, de um lado, as que decorrem das clássicas funções do Estado - as funções legislativa, judicial e executiva, exercidas pelos Poderes estatais (Legislativo, Executivo e Judiciário) - e, de outro, as atividades administrativas executadas pela Administração Pública, que consistem na aplicação e execução da lei e na produção de atos jurídicos complementares.

As funções clássicas do Estado são as de poder ou de governo, vale dizer, as relacionadas ao exercício do poder estatal. A divisão funcional do poder, também conhecida como separação dos poderes, tem sua origem na idéia que predominou no século XVIII, de limitar o exercício do poder do Estado. De acordo com essa teoria, o poder do Estado, embora uno, pode ser exercido de forma dividida, de modo a evitar que fique concentrado em mãos de uma só pessoa ou órgão. Essa é a idéia central da teoria da separação dos poderes, tal qual concebida por Montesquieu, em sua obra $O$ espírito das leis. ${ }^{1}$

De acordo com a doutrina da separação dos poderes, a função legislativa elabora a lei, a função jurisdicional aplica o direito aos casos concretos, resolvendo as questões de conflitos de interesses, e a função executiva exerce atividades de decisão política e de administração pública, desdobrando-se em funções de governo e administrativa. ${ }^{2}$

\footnotetext{
${ }^{1}$ MONTESQUIEU, Charles Louis de Secondat, Baron de La Brède et de. O espírito das leis. Tradução de Fernando Henrique Cardoso e Leôncio Martins Rodrigues. Brasília: Editora da Universidade de Brasília, 1982. Livro XI, Cap. VI.

${ }^{2}$ Reconhece-se, contudo, que se na teoria essa separação parece simples, na prática separar administração e governo não é tarefa assim tão fácil, como aponta Odete Medauar: "Na época contemporânea aumentou a importância da atividade administrativa na dinâmica do Estado e uma das consequiências disso é a participação de servidores (isto é, da chamada burocracia) em atividades que seriam típicas de governo, tais como: fixação do conteúdo de projetos de lei, fixação do teor de regulamentos e decretos, apresentação de propostas que se transformam em realização concreta ou ato normativo." (MEDAUAR, Odete. Direito administrativo moderno. 5. ed. São Paulo: Revista dos Tribunais. 2001. p. 143).
} 
É no contexto da função administrativa desempenhada pela Administração Pública que se colocam as chamadas atividades administrativas, exercidas para "cumprir as tarefas que o ordenamento lhe confere, atividades essas de diferentes tipos, sob vários regimes", nas palavras de Odete Medauar. ${ }^{3}$

Várias são as classificações das atividades administrativas apontadas pela doutrina. Dentre elas, há uma primeira divisão clássica, elaborada pelo italiano Orlando em 1900, que distingue duas modalidades: a atividade jurídica e a atividade social exercida pela administração pública. As atividades jurídicas destinam-se a "assegurar o direito entre as pessoas e harmonizar os vários direitos dos indivíduos entre si e com o interesse público; aí se incluem a organização da Administração, a polícia, a desapropriação, a tutela dos indivíduos ante os atos da Administração. Nesse campo predomina a face da autoridade". 4

A atividade social, que a doutrina moderna denomina material, visa ao bem-estar e ao progresso social, "ressaltando-se a atuação estatal nos setores da saúde, agricultura, educação. Predomina, nesta modalidade de atividade, a face prestadora de serviços úteis ao atendimento de necessidades dos indivíduos". 5

Essa classificação opõe os atos jurídicos de poder público, atos que expressam a atuação da Administração Pública enquanto poder público - praticados no exercício das prerrogativas públicas, e que não podem ser delegados - aos atos materiais, praticados pela Administração Pública e que podem ser delegados aos particulares, já que não envolvem delegação do poder jurídico, exclusivo do Estado.

Outra classificação das atividades administrativas é a formulada por Jordana de Pozas, que distingue as atividades administrativas em serviço público, fomento e polícia administrativa $^{6}$. Essa classificação é adotada por muitos na moderna doutrina administrativista, que, todavia, nela inclui outra modalidade de atividade, a intervenção do

\footnotetext{
${ }^{3}$ MEDAUAR, Odete, Direito administrativo moderno, cit., p. 119.

${ }^{4}$ Ibidem, p. 120.

${ }^{5}$ Ibidem, mesma página.

${ }^{6}$ JORDANA DE POZAS, Luis. Ensayo de una teoría del fomento en el derecho administrativo. Revista de Estudios Políticos, Madrid, n. 48, p. 41-54, 1949, Disponível em: <http://www.cepc.es/rap/Publicaciones/Revistas/2/REP_048_040.pdf>. Acesso em: 12 jan. 2009.
} 
Estado no domínio econômico. Essa é a classificação que melhor atende aos objetivos deste trabalho, razão pela qual as atividades assim classificadas serão a seguir examinadas.

A atividade de fomento envolve auxílios financeiros ou subvenções, financiamentos, favores fiscais e desapropriações ${ }^{7}$. São atividades executadas pelo Estado e que têm por objetivo conceder benefícios aos particulares para que atuem em determinada área que interessa à Administração Pública desenvolver.

A atividade de polícia administrativa impõe restrições e limites ao exercício de direitos e liberdades, em beneficio do interesse coletivo. Constitui, na lição de Hely Lopes Meirelles, a "faculdade de que dispõe a Administração Pública para condicionar e restringir o uso e gozo de bens, atividades e direitos individuais, em beneficio da coletividade ou do próprio Estado". ${ }^{8}$

Edmir Netto de Araújo, com propriedade, indica que as características da polícia administrativa são: (a) atividade predominantemente negativa; (b) atividade que provém privativamente de autoridade pública; (c) atividade predominantemente discricionária; (d) atividade auto-executória da Administração; e (e) coercibilidade das normas emanadas do poder de polícia. ${ }^{9}$

Além dessas duas atividades, há as denominadas de intervenção do Estado no domínio econômico e de serviço público. ${ }^{10}$

A atividade de intervenção do Estado no domínio econômico caracteriza-se pelo ingresso do Estado em um campo que ordinariamente está reservado à atuação privada. Assim, essa atuação tanto pode ser simplesmente jurídica, quando o Estado regula e

\footnotetext{
${ }^{7}$ DI PIETRO, Maria Sylvia Zanella. Direito administrativo. 19. ed. São Paulo: Atlas. 2005. p. 73.

${ }^{8}$ MEIRELLES, Hely Lopes. Direito administrativo brasileiro. 20. ed. São Paulo: Malheiros, 1990. p. 115.

${ }^{9}$ ARAÚJO, Edmir Netto de. Curso de direito administrativo. 3. ed. São Paulo: Saraiva. 2007. p. 999-1001.

${ }^{10}$ A doutrina costuma indicar as quatro atividades como próprias da Administração Pública. O critério não é unânime e há quem especifique ainda mais tais atividades. É o caso de Celso Antonio Bandeira de Mello, que enumera sete atividades administrativas, a saber: serviço público, intervenção no domínio econômico, cumprimento de normas legais que estabelecem as limitações administrativas à liberdade e à propriedade, imposição de direitos e gestão de bens públicos. Nessa classificação, não indica o fomento entre as atividades estatais. (Curso de direito administrativo. 24. ed. São Paulo: Malheiros, 2007. p. 615).
} 
fiscaliza a atividade econômica, como material, quando o Estado atua diretamente no domínio econômico.

O primeiro tipo de intervenção do Estado no domínio econômico, e que tem fundamento constitucional, se faz através de uma atuação jurídica, reguladora e fiscalizadora da atividade econômica. O artigo 174 da Constituição Federal prevê a atuação do Estado como agente normativo e regulador da atividade econômica, exercendo as funções de fiscalização, incentivo e planejamento.

A atuação direta do Estado no domínio econômico "só será permitida quando necessária aos imperativos da segurança nacional ou a relevante interesse coletivo" (art. 173 da $\mathrm{CF}$ ) e, em conseqüência, regra geral é que a atuação no âmbito econômico seja realizada por entes privados, cabendo ao Estado apenas uma ação residual.

Quando o Estado age no domínio econômico, por sua vez, em sendo essa uma atividade tipicamente privada, a sua atuação se faz sempre no regime de direito privado, como preceitua o parágrafo $1^{\circ}$ do artigo 173 da Constituição Federal, que dispõe:

\footnotetext{
“§ $1^{\circ}$ - A lei estabelecerá o estatuto jurídico da empresa pública, da sociedade de econômica mista e de suas subsidiárias que explorem atividade econômica de produção ou comercialização de bens ou prestação de serviços dispondo sobre (...)

II - a sujeição ao regime jurídico próprio das empresas privadas, inclusive quanto aos direitos e obrigações civis, comerciais, trabalhistas e tributários."
}

Em consequiência dessas disposições constitucionais e do que está previsto no parágrafo único do artigo 170 da Constituição Federal, que assegura ao particular o "livre exercício da atividade econômica, independente de autorização de órgãos públicos, salvo nos casos previstos em lei”, os espaços de atuação do particular e do Estado no domínio econômico estão bastante delimitados e caracterizados. A ação estatal é residual e a atuação particular é a regra.

É verdade que o exercício da livre iniciativa, contudo, não é ilimitado, pois encontra os seus limites na sua função social, como bem anotou o Ministro Cezar Peluso: 


\begin{abstract}
"O que ocorre é que o princípio da livre iniciativa, inserido no caput do artigo 170 da Constituição Federal, nada mais é do que uma cláusula geral cujo conteúdo é preenchido pelos incisos do mesmo artigo. Esses princípios claramente definem a liberdade de iniciativa não como uma liberdade anárquica, porém social, e que pode, conseqüentemente, ser limitada."
\end{abstract}

A doutrina faz uma distinção entre atividade econômica em sentido estrito e serviço público $^{12}$, ambas espécies do gênero atividade econômica em sentido amplo. Assim, do gênero atividade econômica, a espécie "atividade econômica em sentido estrito" é uma atividade em regra atribuída aos particulares, e a espécie "serviço público" é, em geral, atribuída ao Estado.

Enfim, a quarta modalidade de atividade administrativa é a rotulada de "serviço público".

As atividades administrativas materiais são as executadas pela Administração Pública e que, ao longo da evolução do Estado, foram se agregando às anteriormente prestadas pela Administração Pública. O conjunto dessas atividades administrativas - as tradicionais e as agregadas - reflete, de modo singular, as alterações havidas na concepção do Estado, desde sua instituição moderna, até o mundo contemporâneo, denunciando de modo especial, para o que interessa aos limites deste trabalho, o grau cada vez maior de interferência do Estado na vida social

Compreendem essas atividades tanto as executadas no dia-a-dia da administração pública, que correspondem basicamente à execução da lei, como as atividades - antigas e novas - que propiciam bens e serviços de toda ordem à população.

\footnotetext{
${ }^{11}$ STF - MC AC n. 1.657, voto do Min. Cezar Peluso, j. 27.06.2007, DJU, de 31.08.2007. Disponível em: $<$ www.stf.gov.br>.

${ }^{12}$ GRAU, Eros Roberto. A ordem econômica na Constituição de 1988: interpretação e crítica. 12. ed. São Paulo: Malheiros, 2007. p. 110.
} 
O serviço público apresenta-se, assim, como uma atividade administrativa material que, em função da sua essencialidade, o Estado assume para si para dotá-la de um regime jurídico próprio, podendo a sua execução ser delegada a terceiros. 


\section{SERVIÇO PÚBLICO EXERCIDO POR PARTICULARES}

\subsection{Serviço público: da execução do serviço pelo Poder Público à possibilidade da execução privada}

A prestação de serviços públicos, desde os primórdios do Estado Liberal, era feita pelo Estado e somente pelo Estado. Naquela época, em que os serviços públicos estavam restritos a um núcleo material relativamente fechado, referente primordialmente aos serviços de polícia e segurança, não se cogitava da prestação de serviço público por particulares.

Tradicionalmente, no período inicial da escola clássica, identificava-se nos serviços públicos a presença de três elementos, subjetivo, formal e material, caracterizados, respectivamente, pela pessoa que presta o serviço público, pelo regime jurídico que regula esse serviço e pela atividade de interesse geral.

No entanto, a partir do momento em que o Estado começou a assumir outras atividades no campo social e econômico, esses elementos passaram por transformações. Assim, atividades que antes eram reservadas à iniciativa privada, ingressaram no campo de atuação do Estado, que passou a desenvolver também atividades comerciais e industriais, alargando-se o âmbito de atuação material do Estado.

Além disso, com o aumento dos serviços prestados pelo Estado, surgiu a necessidade de se transferir a execução de parte do serviço público aos particulares, a fim de atender às necessidades de "especialização" e "de métodos de gestão privados de administração". ${ }^{13}$

A percepção de que o Estado não dispunha de uma estrutura organizacional adequada para a prestação dos serviços levou às concessões de serviço público e ao início

\footnotetext{
${ }^{13}$ DI PIETRO, Maria Sylvia Zanella. Parcerias na administração pública. 5. ed. São Paulo: Malheiros, 2005. p. 68 .
} 
da gestão de serviços públicos por particulares, em algumas situações sem contrato ou concessão. $^{14}$

Verificou-se então uma alteração da regra de que os serviços públicos deviam ser executados pelo Estado e passou-se a admitir, até como regra geral, a execução dos serviços pelo particular ${ }^{15}$, remanescendo como exceção a prestação dos serviços públicos pelo Estado. Em consequiência, alterou-se a concepção do elemento subjetivo do serviço público, pois o serviço não era mais exclusivamente prestado pelo Estado.

Afora isso, também se verificou alteração no elemento objetivo: o regime jurídico de direito público, que era a regra adotada para o exercício das atividades de serviço público, foi substituído, em algumas situações, pelo regime jurídico de direito privado, como ocorreu no caso da Societé Commerciale de l'Ouest Africain, conhecido como o arrêt Bac de Eloka ${ }^{16}$, julgado pelo Tribunal de Conflitos da Colônia francesa da Costa do Marfim em 1921; a Corte estendeu a aplicação do direito privado no julgamento de questão relativa ao afundamento de uma balsa que transportava automóveis, decidindo que a ação deveria ser julgada pela Justiça Comum, pois não demandava, no caso, a aplicação do direito público.

Outras decisões jurisprudenciais ${ }^{17}$ evidenciaram as alterações sofridas na prestação dos serviços públicos, com o conseqüente abalo da concepção original da atividade.

Tais modificações levaram à denominada crise do serviço público ${ }^{18}$, uma vez que os tradicionais parâmetros da atividade não mais se aplicavam à nova prestação de serviços, alterando-se, em decorrência, os critérios tradicionais de análise da atividade denominada serviço público, adotada desde a escola clássica. Por essas razões, houve

${ }^{14}$ GROTTI, Dinorá Adelaide Musetti. O serviço público e a Constituição brasileira de 1988. São Paulo: Malheiros, 2003. p. 53.

${ }^{15}$ Ibidem, mesma página.

${ }^{16}$ MEDAUAR, Odete. Serviço público. Boletim de Direito Administrativo, São Paulo, v. 8, n. 12, p. 723-731, dez. 1992. Ver também: GROTTI, Dinorá Adelaide Musetti, O serviço público e a Constituição brasileira de 1988, cit., p. 53.

${ }^{17}$ MEDAUAR, Odete, Serviço público, cit., p. 723-731.

${ }^{18}$ A crise do serviço público é o nome da obra de Jean-Lois Corail, publicada na década de 1950, apud, MEDAUAR, Odete. $O$ direito administrativo em evolução. 2. ed. São Paulo: Revista dos Tribunais, 2003. p. 216. 
quem propusesse o fim dessa noção, que lhe fosse atribuído outro nome, ou ainda que se declarasse sua inutilidade ou, mesmo, que fosse ela "aposentada". ${ }^{19}$

A crise dos serviços públicos foi assim sintetizada por Pedro Gonçalves:

"Em termos muito gerais, pode dizer-se que, ao longo da sua vida, iniciada em 1873, com uma decisão do Tribunal de Conflitos francês (decisão Blanco) o serviço público sofreu duas crises graves: a primeira, limitada ao Direito Francês, verificada quando o serviço público deixou de ser o critério do direito administrativo por a administração ter começado a usar instrumentos de direito privado na gestão de actividades públicas: quebrava-se a conexão serviço público-regime de direito público e, com isso, um dos interesses essenciais que o conceito pretendia servir." 20

O autor português também faz menção a outra crise na noção dos serviços públicos, mais moderna, resultado das privatizações iniciadas à partir da metade do século XX:

\begin{abstract}
"A segunda, que de certo modo estamos ainda a viver, é uma crise institucional ou material que afecta todos os sistemas administrativos em que o conceito de serviço público se aplica (pelo menos também) às actividades administrativas econômicas e empresariais ligadas à administração de prestações, pelo menos nos sectores das telecomunicações, da energia e do transporte.

Nesses sectores, o serviço público foi ou está sendo pura e simplesmente banido e substituído por conceitos mais ou menos próximos (serviço universal, actividades privadas com obrigações de serviços públicos, actividades privadas de interesse público).,"21
\end{abstract}

Essas crises, na verdade, são o resultado das "dificuldades de acomodação da construção francesa tradicional a novas realidades sócio e econômicas, políticas e tecnológicas" ${ }^{22}$, ou do declínio da noção tradicional de serviço público, que passou a mostrar-se em "dissonância com a realidade em face da mudança de condições sociais traduzidas em vários procedimentos do Estado pós-liberal”. ${ }^{23}$

\footnotetext{
${ }^{19}$ MEDAUAR, Odete, $O$ direito administrativo em evolução, cit., p. 216. Ver também: MEDAUAR, Odete, Serviço público, cit., p. 723-731.

${ }^{20}$ GONÇALVES, Pedro. A concessão de serviços públicos: uma aplicação da técnica concessória. Coimbra: Almedina, 1999. p. 27.

${ }^{21}$ Ibidem, mesma página.

22 ARAGÃO, Alexandre Santos de. Direito dos serviços públicos. Rio de Janeiro: Forense Universitária, 2007. p. 77.

${ }^{23}$ GROTTI, Dinorá Adelaide Musetti, O serviço público e a Constituição brasileira de 1988, cit., p. 60.
} 
No entanto, as idéias mais radicais, que propunham o fim da noção do conceito de serviço público, foram contestadas por diversos autores que, de forma unânime, reafirmam a indispensabilidade da noção. ${ }^{24}$

Nos dias de hoje, o direito brasileiro reconhece a existência de serviços públicos prestados tanto pelo Estado como pelo particular, e os elementos comuns às atividades qualificadas como serviço público são o vínculo orgânico com a Administração que, contudo, não significa necessariamente uma atividade prestada por órgão público, e o regime jurídico de direito público. O vinculo orgânico significa: (a) presunção de serviço público, que pode ser exercido pelo Poder Público, quando se presume que o serviço é público, e pelo particular, quando se presume tratar-se de atividade privada; e (b) relação de dependência entre a atividade e a administração. ${ }^{25}$

Há, contudo, diferenças entre a prestação dos serviços pelo Estado e pelo particular, pois o objetivo do particular é o lucro, e o Estado é movido pelo interesse público, e não pelo lucro.

Nas palavras de Celso Antonio Bandeira de Mello: "Para o concessionário, a prestação do serviço é o meio através do qual obtém o fim que almeja: o lucro. Reversamente, para o Estado, o lucro que propicia ao concessionário é o meio por cuja via busca a sua finalidade, que é a boa prestação do serviço público." 26

Também é diferente o regime jurídico que incide na prestação dos serviços.

Quando a prestação dos serviços é realizada pelo Estado diretamente, incidem as regras de direito público, que não têm aplicação plena quando prestado o serviço por pessoas jurídicas de direito privado; as normas do regime jurídico e os critérios para identificá-las também variam quando os serviços são prestados por certos entes rotulados como entes da Administração Indireta.

\footnotetext{
${ }^{24}$ MEDAUAR, Odete, Serviço público, cit., p. 727.

${ }^{25}$ Ibidem, p. 729.

${ }^{26}$ BANDEIRA DE MELLO, Celso Antonio, Curso de direito administrativo, cit., p. 696.
} 
Assim, no que se refere à execução, os serviços públicos podem ser prestados pelo Estado diretamente ou por intermédio dos entes da Administração indireta, assim como por particulares, aos quais fica delegada a execução dos serviços. A Constituição de 1988 mantém para o Poder Público a titularidade dos serviços e, portanto, somente a execução dos mesmos é transferida, mediante delegação, ao particular, que deverá respeitar as regras específicas ditadas pela lei ou pelo contrato de execução dos serviços.

\subsection{Fundamentos constitucionais do serviço público}

A Constituição de 1988 não conceitua ou define serviço público. Não obstante, permite caracterizá-lo sob vários aspectos, na medida que dispõe sobre a matéria em preceitos constitucionais esparsos, pelo que se pode afirmar que no Brasil o serviço público é dotado de fundamentos constitucionais fixados pelo texto de nossa Lei Maior.

Diante disso, é possível admitir que a estrutura jurídica básica dos serviços públicos no Brasil está inserida na Constituição Federal, que trata do assunto em diversos dispositivos, os quais indicam, dentre outros aspectos, os órgãos ou poderes competentes para exercer o serviço público, as atividades que dele podem ser objeto, a forma pela qual pode ser prestado o serviço público no Brasil e o regime jurídico dos entes que prestam serviço público.

Assim, no que respeita à atribuição de competência para o exercício de serviços pelos poderes públicos, mencionem-se, por primeiro, os incisos X, XI e XII, do artigo 21, da Constituição Federal, que arrolam serviços ou atividades que devem ser prestadas pela União no exercício de sua competência federativa. São os serviços de serviço postal e de correio aéreo nacional, os de telecomunicações, de radiodifusão sonora e de imagens, de instalação de energia elétrica e o aproveitamento energético dos cursos d'água, a navegação aeroespacial e a infra-estrutura aeroportuária, os serviços de transporte ferroviário e aquaviário entre portos brasileiros e fronteiras nacionais, ou que transponham os limites do Estado ou território, os serviços de transportes rodoviário interestadual e internacional, os portos marítimos, fluviais e lacustres. 
O parágrafo $2^{\circ}$ do artigo 25, por sua vez, confere aos Estados a prerrogativa de explorar os serviços locais de gás canalizado e o inciso V do artigo 30 dá aos Municípios a incumbência de organizar e prestar os serviços públicos de interesse local, incluído o de transporte coletivo, que tem caráter essencial.

Há, por outro lado, exemplificando, a atribuição de atividades administrativas materiais, caracterizadas como serviços públicos, que podem ser extraídas do artigo 23 da Constituição, que estabelece competências materiais comuns dos entes federativos, ou do rol das competências legislativas dos entes federativos (arts. 22, 24, 30).

Já no que respeita à forma de exercício dos serviços públicos, o artigo 175 da Constituição prescreve duas modalidades de prestação dos serviços públicos: a prestação direta pelo Poder Público e a prestação indireta, mediante delegação aos particulares, sempre mediante licitação, por concessão ou permissão. Dispõe referido artigo:

\footnotetext{
"Artigo 175 - Incumbe ao Poder Público, na forma da lei, diretamente ou sob regime de concessão ou permissão, sempre através de licitação, a prestação de serviços públicos."
}

Por sua vez, o artigo 223, caput, também cuida de formas de prestação de serviços pelo Estado, ainda que referidas expressamente a apenas uma espécie de serviço público, acrescentando, dentre elas, nova modalidade. Com efeito, dispõe o caput de referido artigo:

\footnotetext{
"Artigo 223 - Compete ao Poder Executivo outorgar e renovar concessão, permissão e autorização para o serviço de radiodifusão sonora e de sons e imagens, observado o princípio da complementaridade dos sistemas privado, público e estatal."
}

Convém mencionar, neste contexto, as disposições contidas nos incisos XI e XII do artigo 21 da Constituição Federal, que também acrescentam, às modalidades de prestação de serviço público por delegação indicadas no artigo 175, a modalidade prevista no artigo 223, qual seja, a "autorização". 27

Além dos serviços acima mencionados, há outras atividades de prestação material atribuída ao Poder Público, caracterizáveis como serviços públicos, que têm previsão

\footnotetext{
${ }^{27}$ Ver, a respeito, as considerações tecidas no item seguinte.
} 
constitucional, como os serviços de educação e de saúde, disciplinados nos artigos 196 e 203, respectivamente, e os serviços de previdência e assistência social, contemplados nos artigos 201 e 202, e 203 e 204, respectivamente.

Celso Antonio Bandeira de Mello sistematizou os serviços públicos prestados no Brasil, tal qual previstos na Constituição Federal, arrolando as seguintes modalidades:

“(a) serviços de prestação obrigatória e exclusiva do Estado;

(b) serviços de prestação obrigatória do Estado e em que é também obrigatório outorgar em concessões a terceiros;

(c) serviços de prestação obrigatória pelo Estado, mas sem exclusividade;

(d) serviços de prestação não obrigatória pelo Estado, mas não os prestando é obrigado a promover-lhes a prestação, tendo, pois, que outorgá-los em concessão ou permissão a terceiros." 28

Os serviços de prestação obrigatória e exclusiva do Estado são o serviço postal e correio aéreo nacional, tal qual previsto no artigo 21, X da Constituição Federal.

De fato, o artigo 21 da Constituição Federal parece ter traçado diferentes formas de execução de serviço público, variando de acordo com o tipo de atividade: os serviços de telecomunicação, de radiodifusão sonora, e de sons e imagens; os serviços e instalações de energia elétrica e o aproveitamento energético dos cursos de água, em articulação com os Estados onde se situam os potenciais hidroenergéticos; a navegação aérea, aeroespacial e a infra-estrutura aeroportuária; os serviços de transporte ferroviário e aquaviário entre portos brasileiros e fronteiras nacionais, ou que transponham os limites de Estado ou Território; os serviços de transporte rodoviário interestadual e internacional de passageiros; os portos marítimos, fluviais e lacustres, todos podem ser prestados diretamente ou mediante concessão, permissão ou autorização.

Essa possibilidade de delegação da execução dos serviços, contudo, no entendimento do autor, não existe para o serviço postal e correio aéreo nacional e, portanto, a intenção do legislador constituinte foi a de obrigar que tais serviços sejam prestados diretamente pela União, sem a possibilidade de delegação.

${ }^{28}$ BANDEIRA DE MELLO, Celso Antonio, Curso de direito administrativo, cit., p. 673. 
Em sentido contrário, Alexandre Santos de Aragão ${ }^{29}$ argumenta que a Constituição Federal de 1988 não instituiu regime de monopólio para os serviços postais e de correio aéreo nacional, como "historicamente" ocorreu no Brasil por expressa disposição do Decreto n. 506/69 e artigo $9^{\circ}$ da Lei n. 6.538/78. Em apoio, cita lição de Luís Roberto Barroso $^{30}$, que argumenta que o serviço postal deve ser entendido com uma atividade estatal de atividade econômica não monopolizada e Floriano Peixoto de Azevedo Marques $\mathrm{Neto}^{31}$, para quem o vocábulo manter, contido no artigo $21, \mathrm{X}$, do texto constitucional determina a obrigação da União de garantir o serviços mas não impede que a sua execução seja delegada a particulares.

Mas, convém citar entendimento do Superior Tribunal de Justiça, que parece entender que enquanto não se alterar a redação do artigo $21, \mathrm{X}$, da Constituição, para possibilitar a prestação dos serviços por outros entes que não a União, não há hipóteses de que tais serviços sejam delegados a particulares, sob pena de inconstitucionalidade. Assim também o Superior Tribunal de Justiça decidiu pela não-recepção da Lei n. 6.538/78, ocasião em que sentenciou que "mesmo que os serviços postais não tenham sido incluídos no rol do artigo 177, não há qualquer impedimento ao estabelecimento do monopólio da União pela Lei Ordinária, ainda que anterior à Constituição Federal (...) o serviço postal foi atribuído com exclusividade à União, direta ou indiretamente - pela criação de específica pessoa jurídica (EBCT), não tendo sido autorizada a delegação de tais serviços a particulares, mediante concessão ou permissão, como ocorrido em outros serviços públicos, a exemplo das telecomunicações." 32

Os serviços de radiodifusão sonora de sons e imagens, rádio e televisão são prestados por entes privados, sendo que a Constituição outorgou competência ao Poder Executivo Federal para renovar tais serviços mediante concessão, a permissão e a

${ }^{29}$ ARAGÃO, Alexandre Santos de, Direito dos serviços públicos, cit., p. 285.

${ }^{30}$ BARROSO, Luís Roberto. Regime constitucional do serviço postal: legitimidade de atuação da iniciativa privada. Revista de Direito da Associação dos Procuradores do Estado do Rio de Janeiro, Rio de Janeiro, Lumen Juris, v. 9, p. 156-158, 2002.

${ }^{31}$ MARQUES NETO, Floriano Peixoto de Azevedo. Reestruturação do setor postal brasileiro. Revista Trimestral de Direito Público, v. 19, p. 149-161, 1997.

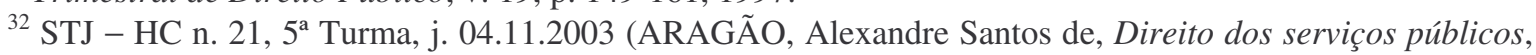
cit., p. 288). Ver também: ADPF n. 46, na qual o Supremo Tribunal discute a natureza do serviço postal como serviço público; e QO ACO n. 765/RJ (pendente de publicação), na qual o Supremo fixou a orientação de que o "serviço postal constitui serviço público, portanto não atividade econômica em sentido estrito". (Informativo 392 do STF. Disponível em: <www.stf.gov.br/publicações>. Acesso em: 18 jan. 2009). 
autorização, ao mesmo tempo em que determina seja observada a complementaridade dos sistemas privado, público e estatal.

Assim, mencionados serviços são, portanto, prestados tanto pelo Poder Público Federal como pelo particular, mediante delegação do Poder Executivo.

Os serviços de educação, saúde, previdência social, assistência social, radiodifusão sonora e de imagens são de prestação obrigatória pelo Estado, mas sem exclusividade, pois o particular também pode prestá-los. Esses serviços, quando prestados pelo Estado União, Estados, Municípios e Distrito Federal - são serviços públicos, mas quando prestados pelo particular, são serviços privados.

Os demais serviços públicos podem ser prestados tanto pelo Estado como pelo particular, mediante o regime de concessão, permissão e autorização.

Com relação ao regime jurídico aplicável à prestação de serviços públicos, algumas disposições constitucionais estabelecem o regime jurídico dos entes públicos ou privados que prestam serviço público. Os órgãos e entes de natureza pública, que integram a Administração Pública, estão sujeitos ao regime jurídico público, e os entes particulares ao regime jurídico privado ${ }^{33}$. Exemplificando, o artigo 173 e seus parágrafos, o parágrafo único do artigo 175, que remete a lei ordinária fixar o regime das concessionárias e permissionárias de serviço público, o artigo 37, que estabelece o estatuto constitucional da Administração Pública, particularmente em seus incisos XIX, XX, XXI e parágrafos $6^{\circ}$ e $9^{\circ}$.

Não obstante toda essa disciplina constitucional contida nos preceitos mencionados e em outros mais, plantados ao longo da Constituição, impõe-se, por primeiro, observar que a Constituição não traça um perfil seguro sobre o que é serviço público no Brasil, conforme se afirmou no início dessas considerações.

\footnotetext{
${ }^{33}$ Sobre os regimes de direito público e privado conferir, dentre outros: DI PIETRO, Maria Sylvia Zanella. Direito Administrativo. São Paulo: Atlas, 2004, p. 57 e ss.
} 
Ante tal disciplina constitucional, várias questões são levantadas a respeito da matéria. Assim, uma das discussões debatidas pela doutrina é a questão sobre se a Constituição esgota, em sua disciplina, as modalidades possíveis de serviço público e as formas de sua prestação. Em outras palavras, discute-se se é possível instituir nova modalidade de serviço público, ou nova modalidade de prestação de serviço público, na esfera federal, por lei ordinária; ou se a instituição de um serviço público ou de nova forma de prestação de serviço público depende de Emenda Constitucional.

Para a grande maioria da doutrina, novos tipos de serviços públicos podem ser instituídos pela legislação infraconstitucional, observados os limites definidos na Constituição.

De acordo com Celso Antonio Bandeira de Mello, é da lei a tarefa de instituir novos serviços públicos, mas com uma condição, “contanto que não sejam ultrapassadas as fronteiras constituídas pelas normas relativas à ordem econômica, as quais são garantidoras da livre iniciativa". 34

Justifica o seu raciocínio partindo da observação de que a Constituição de 1988 atribuiu ao particular o exercício da atividade econômica como regra. Entretanto, não há uma definição do que sejam atividades econômicas na Carta Magna, e a consequiência deste fato é que "remanesce ao legislador ordinário certo campo para qualificar determinadas atividades como 'serviços públicos', no que, indiretamente gizará, por exclusão, a área configurada como das 'atividades econômicas", 35

Mas não há absoluta liberdade ao legislador ordinário para instituir novos serviços públicos, uma vez que, segundo explica, ante a uma indefinição do que sejam atividades econômicas no texto constitucional, deve-se entender a expressão no "sentido comum da expressão, isto é, o prevalente ao lume dos padrões de cultura de uma época, das convicções predominantes da sociedade". 36

\footnotetext{
${ }^{34}$ BANDEIRA DE MELLO, Celso Antonio, Curso de direito administrativo, cit., p. 639.

${ }^{35}$ Ibidem, p. 640.

${ }^{36}$ Ibidem, mesma página.
} 
Assim, embora a Constituição não tenha definido o que seja serviço público e atividade econômica em sentido estrito, é certo que a Constituição atribuiu o espaço econômico, que se divide com os serviços públicos, ao particular; assim, o limite à instituição de uma atividade no regime de serviço público é o da atividade econômica, definido pelos "padrões de cultura de uma época".

Dinora Adelaide Musseti Grotti, que adota esta mesma linha, sintetiza o raciocínio da seguinte forma:

\begin{abstract}
"Em primeiro lugar o serviço deve estar dentro das competências da pessoa jurídica instituidora. Em segundo lugar deve respeitar as indicações constantes do artigo 173, que deixam clara a excepcionalidade da exploração direta de atividade econômica pelo Estado, isto é, não serem tidas como próprias dos particulares num dado local e momento do contrário dar-se-ia uma transformação artificial de atividades econômicas em serviços públicos, como o intuito sub-reptício de estatizála, resvalando para o campo da inconstitucionalidade.

$\mathrm{Na}$ linha de Celso Antonio Bandeira de Mello, será o conceito algo vago, um tanto fluido de 'atividade econômica' que definirá a linha divisória final entre as duas órbitas, com a ressalva de que, do ponto de vista jurídico, será de interesse público a solução que haja adotada pela Constituição ou consagrada nas leis afinadas com as diretrizes da Lei Maior." $37^{3}$
\end{abstract}

A este respeito, observa Maria Sylvia Zanella di Pietro que:

"É o Estado, por meio de Lei, que escolhe quais as atividades que, em determinado momento, são consideradas serviços públicos; no direito brasileiro, a própria Constituição faz essa indicação nos artigos 21, incisos X, XI, XII, XV e XXIII, e $25 \S 2^{\circ}$, alterados, respectivamente, pelas Emendas Constitucionais 8 e 5, de 1995; isto exclui a possibilidade de distinguir, mediante critérios objetivos, o serviço público da atividade privada; esta permanecerá como tal enquanto o Estado não a assumir como própria., 38

Para Carmem Lúcia Antunes Rocha, é possível dar a uma atividade o regime jurídico de serviço público por via de lei ordinária, mas, contudo, há limites. Assim, ensina que:

${ }^{37}$ GROTTI, Adelaide Musetti, O serviço público e a Constituição Brasileira de 1988, cit., p. 106.

${ }^{38}$ DI PIETRO, Maria Sylvia Zanella, Direito administrativo, cit., p. 114. 
"Há de serem relevados os elementos definidores da natureza da atividade e sua afinidade com a obrigação estatal de suprir um interesse público específico, verificando-se se é da competência exclusiva ou prioritária do Poder Público ampará-lo ou realizá-lo, a fim de que possa subsumir o tema ao regime de direito público". ${ }^{39}$

Em sentido contrário, Fernando Herren Aguillar $^{40}$ sustenta a necessidade de emenda constitucional para que seja instituído um novo tipo de serviço público. Para ele, a falta de um conceito jurídico de serviço público na atual Constituição impede que o legislador ordinário dê regime jurídico de serviço público a uma atividade.

Aguillar observa, ainda que "dar regime de serviço público a uma atividade é restringir o acesso dos particulares ao mercado respectivo". É possível se fazer um raciocínio semelhante com relação à atuação do Estado na atividade econômica, o que justificou inserir condições para esta atuação estatal (art. $173 \mathrm{CF}$ ) e, se para o Estado atuar em regime de concorrência com o setor privado a Constituição impôs condições, e silenciou com relação a instituição de um serviço público, então significa que não é possível, se não por emenda constitucional instituir serviço público no Brasil.

Ante todo exposto, e considerando a sistema constitucional, que deve ser visto como dotado de unidade e coerência, e o tipo de Estado adotado pela Constituição de 1988, parece possível extrair, para os fins que interessam a este trabalho, algumas ilações decorrentes das normas constitucionais que fundamentam o exercício da atividade administrativa, sob a modalidade de serviço público.

Em primeiro lugar, o que caracteriza uma atividade administrativa como serviço público, a partir do texto constitucional, é a sua titularidade. Em outras palavras, as atividades materiais de prestação à comunidade, atribuídas ao Poder Público pela Constituição, constituem serviço público. E, sob este aspecto, a Constituição parece esgotar as modalidades de serviços públicos existentes com relação à União - já que a Constituição Federal disciplina, de modo expresso, a atuação administrativa da União -, o que significa dizer não ser possível a instituição de outras espécies de serviços públicos

\footnotetext{
${ }^{39}$ ROCHA, Carmen Lúcia Antunes. Estudo sobre concessão e permissão de serviço público no direito brasileiro. São Paulo: Saraiva, 1996. p. 20.

40 AGUILlAR, Fernando Herren. Direito econômico: do direito nacional ao direito supranacional. São Paulo: Atlas, 2006. p. 264.
} 
federais que não as previstas na Constituição Federal. Isso porque, além de outros fundamentos, a Constituição assegura, tanto no Título VIII, destinado à disciplina da Ordem Social, como no Título II, dedicado aos Direitos e Garantias Fundamentais, a iniciativa privada, ou o direito de exercício de qualquer atividade que não esteja compreendida nas atribuições do Poder Público. Assim, a caracterização, como serviço público, de atividades compreendidas no âmbito da atividade privada, mesmo por emenda constitucional, poderá encontrar óbice nas limitações postas pelo artigo 60 da Constituição ao Poder Constituinte de Reforma Constitucional.

Convém registrar, todavia, que a Constituição Federal não disciplina - porque não é matéria própria dela - as modalidades de serviço público a serem prestadas pelos Estados e pelos Municípios, já que a atividade administrativa material de serviço público é matéria de competência dos entes federativos que, na hipótese, apenas devem respeitar as regras expressas fixadas na Constituição Federal, quando as houver. Assim, as modalidades de serviços públicos, no âmbito dos Estados Federados, Distrito Federal e Municípios, devem ser fixadas nas respectivas leis maiores - Constituição Estadual, Lei Orgânica Distrital e Lei Orgânica dos Municípios, ressalvados os serviços públicos já previamente estabelecidos na Constituição Federal, tais como os dos artigos 25 , parágrafo $2^{\circ}$ (atribuição aos Estados da exploração de gás) e 30, inciso V (exercício pelos Municípios dos serviços de transporte coletivo urbano). A atividade de serviço público, nos Estados, decorre de suas competências reservada ou remanescente, previstas no parágrafo $1^{\circ}$ do artigo 25 , e das competências legislativas concorrentes e comuns (arts. 24 e 23); as dos Municípios têm fundamentos em suas competências para legislar sobre assuntos de interesse local (art. 30, I), e para executar os serviços públicos de interesse local (art. 30, V), além dos serviços públicos que podem derivar das competências concorrentes, fixadas ao longo do texto constitucional e das competências comuns, estabelecidas no artigo 23. Para exemplo, a Lei Orgânica do Município de São Paulo estabelece, em seu artigo 125, que “constituem serviços públicos municipais, dentre outros: I - administrar o serviço funerário e os cemitérios públicos, fiscalizando aqueles pertencentes às entidades privadas; administrar a coleta, o tratamento e o destino do lixo; III - efetuar a limpeza das vias e logradouros públicos. ${ }^{41}$

\footnotetext{
${ }^{41}$ Para exame da distribuição de competências na Constituição ver: ALMEIDA, Fernanda Dias Menezes de. Competências na Constituição de 1988. 2. ed. São Paulo: Atlas, 2000.
} 
Em segundo lugar, o serviço público, segundo a regra geral do artigo 175 e as regras especiais do artigo 223 e dos incisos XI e XII do artigo 21, fixadas pela Constituição, poderá ser prestado diretamente pelo Poder Público, ou indiretamente, pelos particulares. No caso do artigo 175, trata-se de disposição geral que alcança todas as entidades federativas - União, Estados, Municípios e Distrito Federal. As modalidades previstas nos artigos 223 e incisos do artigo 21, acima referidas, e atribuídas à União, poderão, segundo o princípio da simetria, consagrado em inúmeras decisões do Supremo Tribunal Federal, se estender, também, aos demais entes federativos, no que couber.

As formas de delegação de prestação de serviços públicos estão, pois, estabelecidas na Constituição. Parece inexistir, contudo, impedimento para que, mediante emenda constitucional, outras modalidades de delegação de prestação de serviço público sejam instituídas no cenário da Administração Pública, desde que observados: de um lado, os princípios regentes da Administração Pública, estabelecidos no caput do artigo 37, (princípios da legalidade, impessoalidade, moralidade, publicidade e eficiência), e de outro, as limitações que incidem sobre o poder de emenda constitucional, previstas no artigo 60 (respeito à forma federativa do Estado, à separação de poderes, aos direitos e garantias individuais). Isso porquanto a "forma" de prestação de serviço público, com as ressalvas acima apontadas, não parece matéria suscetível de afetar normas ou regras constitucionais estabelecidas no texto de nossa Lei Suprema.

Por fim, o regime jurídico dos prestadores de serviço público tem como base disposições constitucionais, sendo que a Constituição admite que, em certos casos, a disciplina desse regime seja estabelecida em lei (art. 175, parágrafo único).

\subsection{As formas de delegação do serviço público no direito brasileiro}

No Brasil, há três formas de delegação de serviços públicos: a concessão, a permissão e a autorização. 
A concessão e a permissão de serviços públicos estão previstas no artigo 175 da Constituição Federal.

$\mathrm{O}$ artigo 175 do texto constitucional regula, de modo geral, as formas pelas quais o serviço público é prestado no Brasil. Convém transcrever novamente, para maior clareza de raciocínio, mencionado texto constitucional.

“Artigo 175 - Incumbe ao Poder Público, na forma da lei, diretamente ou sob regime de concessão ou permissão, sempre através de licitação, a prestação de serviços públicos."

A disciplina constitucional dessa matéria pode levar a diferentes conclusões, impondo-se, por essa razão, proceder a uma interpretação sistemática do texto constitucional.

Em primeiro lugar, refere-se o texto constitucional ao Poder Público. Essa expressão deve ser compreendida como se referindo ao Poder Executivo ${ }^{42}$, particularmente na sua face de "Administração Pública", já que é ela, no sistema da separação de poderes, como visto, que se encarrega primordialmente da execução de atividades materiais estatais correspondentes aos serviços públicos, ou que, em outras palavras, mantém a titularidade, constitucionalmente deferida, para a prestação de serviços públicos.

Assim, alcança o texto constitucional o Poder Público ou a Administração Pública de todos os entes federativos: União, Estados, Municípios, Distrito Federal, valendo dizer que incumbe ao Poder Público ou à Administração Pública desses três níveis de governo a prestação de serviços públicos, na forma da lei, diretamente ou sob o regime de concessão ou permissão, sempre mediante licitação.

A autorização vem disciplinada no artigo 223 e nos incisos, XI e XII do artigo 21. Também aqui convém transcrever os citados dispositivos.

"Artigo 223 - Compete ao Poder Executivo outorgar e renovar concessão, permissão e autorização para o serviço de radiodifusão sonora e de sons e

42 CRETElla JUNIOR, José. Comentários à Constituição de 1988 (arts. 170 a 232). 2. ed. Rio de Janeiro: Forense Universitária, 1993. v. 8, p. 4.073-4.075. 
imagens, observado o princípio da complementaridade dos sistemas privado, público e estatal.”

“Artigo 21 - Compete à União:

(...)

XI - explorar, diretamente ou mediante autorização, concessão ou permissão, os serviços de telecomunicações, nos termos da lei, que disporá sobre a organização dos serviços, a criação de um órgão regulador e outros aspectos institucionais;

XII - explorar, diretamente ou mediante autorização, concessão ou permissão:

a) os serviços de radiodifusão sonora e de sons e imagens;

b) os serviços e instalações de energia elétrica e o aproveitamento energético dos cursos de água, em articulação com os Estados onde se situam os potenciais hidroenergéticos;

c) a navegação aérea, aeroespacial e a infra-estrutura aeroportuária;

d) os serviços de transporte ferroviário e aquaviário entre portos brasileiros e fronteiras nacionais, ou que transponham os limites de Estado ou Território;

e) os serviços de transporte rodoviário interestadual e internacional de passageiros;

f) os portos marítimos, fluviais e lacustres;"

Como se vê, quando utiliza a expressão "autorização", o texto constitucional menciona um terceiro tipo de delegação de serviços públicos aos particulares, apesar de não ter feito menção a essa modalidade de prestação de serviços públicos na regra geral no artigo 175 .

A inclusão da nova figura de delegação - a autorização - traz inicialmente a idéia de que o legislador constituinte não empregou no texto constitucional uma técnica uniforme para designar os modos de prestação de serviços públicos por delegação. Isso porque não inseriu a "autorização" no texto do artigo 175 - que é a regra geral sobre a disciplina jurídica das formas de delegação do serviço público. A menção à delegação por autorização, como se viu, aparece apenas no artigo 223 e nos incisos XI e XII do artigo 21, que trata da competência material da União.

Como a Constituição brasileira dispõe sobre a matéria de modo expresso, conforme já se salientou, a introdução de novas formas de delegação de serviço público a particulares parece depender de emenda constitucional, uma vez que a disciplina jurídica sobre as modalidades de formas de prestação de serviços públicos é no Brasil matéria constitucional. 
Assim, para que fosse possível introduzir novas formas de delegação de serviço público aos particulares parece necessário alterar o artigo 175 da Constituição, introduzindo-se novas formas de delegação ou, eventualmente, remetendo-se à legislação ordinária a possibilidade de instituição de novas formas de delegação de serviços públicos porque, cabe acrescentar, a Constituição brasileira é rígida e analítica e, como tal, debruçase sobre matérias que, na verdade, deveriam ficar para a regulamentação do direito infraconstitucional.

O constituinte federal não se deu conta, na verdade, de que, com a evolução do Estado na prestação de serviços públicos, certamente a demanda por novas fórmulas de prestação iriam surgir no âmbito da Administração Pública, o que poderia encontrar dificuldades de aplicação, diante da rigidez do texto constitucional. Para evitar tais dificuldades, parece, bastaria, resguardando o interesse público, o interesse dos administrados e o da própria Administração Pública, fixar princípios a serem seguidos para a prestação de serviços públicos por particulares, tais como os do artigo 37, já estabelecidos pelo constituinte, e o da licitação, também previsto no artigo 175 , a serem observados em qualquer modalidade de prestação de serviços públicos por particulares, ficando à legislação infraconstitucional estabelecer as regras para concretizá-los e as modalidades de sua prestação. Como a legislação infraconstitucional pode ser alterada com maior facilidade, poderia ela ir absorvendo as modalidades de prestação de serviços públicos que fossem surgindo no mundo contemporâneo.

A doutrina, diante do texto constitucional e da realidade contemporânea, encontra, como solução para a questão, alargar o conceito do termo "concessão", inserido no artigo 175, que, guardados os requisitos constitucionais essenciais - transferência de serviço público aos particulares mediante licitação - passaria a admitir outras fórmulas de concessão, com novos rótulos, pelo que se passaria a considerar o termo concessão em um sentido genérico e em sentidos específicos.

Assim, não se pode ignorar que existe, no plano do direito administrativo infraconstitucional, a admissão de novas formas de delegação serviço público mediante um "alargamento" do conceito e da amplitude da concessão, permitindo abrigar novas formas 
que se sujeitariam ao regime jurídico da concessão de serviços públicos. Nesse sentido o pensamento de Marçal Justen Filho: “O instituto da concessão pode materializar-se de diferentes modos. A definição não elimina essa variedade de figuras. Não se deve considerar que todas as concessões devam contemplar regras similares e soluções idênticas quanto à responsabilidade do concessionário de seus encargos."43

A possibilidade de se admitir outras formas de prestação de serviço público, que não as previstas no texto constitucional brasileiro, tem origem e inspiração no direito estrangeiro, sobretudo no direito francês, que já incorporou ao seu ordenamento jurídico novas formas de delegação de serviço público ${ }^{44}$. Ressalte-se, contudo, que o direito francês obedece a regras próprias e diferentes do sistema jurídico adotado no Brasil. Na França, o direito administrativo é construído a partir do sistema de dualidade de jurisdição e é fundamentalmente pretoriano, exercido através de tribunais administrativos que, a partir do julgamento de casos concretos, criou um sistema de princípios que passaram a orientar a conduta da Administração Pública. ${ }^{45}$

No Brasil, o sistema jurídico administrativo é o da chamada civil law, de jurisdição una, fundado no direito positivo, de tal sorte que a Administração Pública tem sua atuação restringida pelos princípios da legalidade e da constitucionalidade, que circunscrevem a atuação administrativa, de forma que a Administração só pode fazer o que a lei autorizar.

Ora, esse sistema de legalidade, forçoso que se reconheça, no mais das vezes é insuficiente para atender à extraordinária demanda da atuação da Administração Pública na modernidade, que dela exige maior agilidade, mais eficiência, e novas fórmulas de atendimento rápido e amplo das necessidades dos administrados.

A limitação constitucional acima indicada - ou seja, a excessiva rigidez do sistema constitucional - imposta ao direito administrativo acaba por induzir a busca de soluções “exógenas" ${ }^{46}$, isto é, soluções que não vêm das fontes normativas do direito administrativo, mas de outras fontes, e que podem suscitar dúvidas relativas à sua constitucionalidade.

\footnotetext{
${ }^{43}$ JUSTEN FILHO, Marçal. Curso de direito administrativo. 2. ed. São Paulo: Saraiva, 2006. p. 510.

44 DI PIETRO, Maria Sylvia Zanella, Parcerias na administração pública, cit., p. 77. Ver também: ARAGÃO, Alexandre Santos de, Direito dos serviços públicos, cit., p. 719.

${ }^{45}$ BUCCI, Maria Paula Dallari. Direito administrativo e políticas públicas. São Paulo: Saraiva, 2002. p. 48.

${ }^{46}$ BUCCI, Maria Paula Dallari, Direito administrativo e políticas públicas, cit., p. 19.
} 
Nesse contexto, surgem as chamadas "parcerias" entre a Administração Pública e entes privados, como uma forma de desafogar a Administração Pública e de dotá-la de mecanismos mais "eficientes" no desempenho do seu papel.

Há formas de execução surgidas no contexto das parcerias que não são hábeis para caracterizar delegação de serviços públicos, tais como a terceirização e o convênio, conforme, aliás, preleciona Edmir Netto de Araújo ao comentar a expressão "parcerias", diz: "Caso se trate de serviços públicos, como fugir-se ao princípio da licitação, às normas disciplinadoras de contratos administrativos, aos princípios da legalidade estrita, da supremacia do interesse público, da continuidade do serviço público, da mutabilidade do regime jurídico, igualdade dos usuários modicidade ou gratuidade tarifária, serviço adequado?"47

A terceirização nada mais é que uma prestação de serviços por terceiros, ou, seja, uma locação de serviços, através da qual terceiros são contratados para prestarem serviços para um ente público qualquer, serviços que não se confundem com a sua atividade-fim.

O convênio é um instrumento de que o Poder Público se utiliza para associar-se com entidades públicas ou privadas; previsto no artigo 116 da Lei n. 8.666/93, diferenciase dos contratos, pois nestes os interesses das partes são opostos e naquele os interesses são comuns. $^{48}$

Os consórcios públicos, previstos pela Lei n. 11.107/2005, podem ser constituídos de uma associação pública ou pessoa jurídica de direito privado $\left(\S 1^{\circ}\right.$ do art. $\left.1^{\circ}\right)$. Admite-se o convênio de entidades públicas com entidades ou instituições privadas, se a associação atender ao interesse público, que poderá ser realizada via convênio ou contrato administrativo, conforme o consórcio se constitua para atividade de fomento ou de execução material de serviço para o Estado $^{49}$. Todavia, o convênio não se presta à

\footnotetext{
${ }^{47}$ ARAÚJO, Edmir Netto de, Curso de direito administrativo, cit., p. 121.

${ }^{48}$ DI PIETRO, Maria Sylvia Zanella, Parcerias na administração pública, cit., p. 246.

${ }^{49}$ GROTTI, Dinora Adelaide Musseti. Contratos de gestão e outros tipos de acordos celebrados pela Administração. Disponível em:

<ttp://www.tcm.sp.gov.br/legislacao/doutrina/14a18_06_04/dinora_mussetti1.htm>. Acesso em: 12 jan. 2009.
} 
delegação de serviço público ao particular, porque se trata de diferentes institutos. Na delegação, o Poder Público transfere uma atividade para o ente privado, o que não acontece no convênio, em que os partícipes são associados e não há transferência de serviços.

Tem-se admitido, contudo, a realização de parceria público-privada pelos consórcios públicos em situações em que, por exemplo, os serviços que se pretende contratar em parceria público-privada não atinge o valor mínimo exigido pela lei (vinte milhões de reais). Nesse caso, vários Municípios formam um consórcio público para, então, contratar o parceiro privado em regime de parceria público-privada. Nessa situação, haverá delegação de serviços do consórcio público ao particular. ${ }^{50}$

Em suma, ante todo o exposto, para fins do escopo deste trabalho, somente cabe o exame das seguintes formas de prestação de serviços públicos: a concessão, como gênero de delegação de serviços públicos, a franquia, a concessão patrocinada e a concessão administrativa, como espécies do gênero concessão, e a permissão e autorização de serviços públicos.

\footnotetext{
${ }^{50}$ PIMENTEL, Darci Fernandes. Modalidades de parcerias entre o poder público e a iniciativa privada na execução de obras elou prestação de serviços públicos. Disponível em:

$<$ http://www.marica.com.br/2005b/2806orlandosf.htm>. Acesso em: 12 jan. 2009.
} 


\section{AS FORMAS DE SERVIÇO PÚBLICO PRESTADO POR PARTICULARES}

\subsection{Concessão de serviços públicos}

\subsubsection{A concessão tradicional}

\subsubsection{Antecedentes}

A concessão de serviços públicos é, em sentido genérico, a forma encontrada pelo Poder Público para delegar serviços que veio assumindo ao longo de sua evolução. Com a conotação atual, a concessão existe e foi utilizada desde o século XIX na França.

No início, duas motivações fundamentavam a delegação ao particular dos serviços públicos: (a) de um lado, a incapacidade de o Estado assumir novas funções derivadas do Estado social. Com efeito, o Estado, inicialmente sob a roupagem do Estado liberal, com atividades restritas a esse campo, passou a adquirir, ao longo de sua evolução, incumbências de natureza social que se transformaram na obrigação de prestação de serviços pelo Poder Público. Diante da insuficiência de material humano especializado e da falta de especialização dos seus funcionários, a absorção pelo Estado dessas novas incumbências estava cercada de dificuldades; (b) de outro, a insuficiência de recursos financeiros para atender às novas prestações públicas. As dificuldades financeiras do erário público fazem com que o Estado perceba que, mediante a possibilidade de delegar os serviços aos particulares, retira de si o encargo de prestar diretamente tais serviços e, o que é mais relevante, exime-se de ter de fazer investimentos para tal finalidade, livrando-se, por consequiência, dos riscos próprios e inerentes à atividade econômica. ${ }^{51}$

\footnotetext{
${ }^{51}$ DI PIETRO, Maria Sylvia Zanella, Direito administrativo, cit., p. 296.
} 
Assim, a concessão desses serviços a entes privados que viessem assumir os serviços por sua conta e risco, mas com a natural expectativa de lucro, parecia ao mesmo tempo resolver um problema para o Estado e atender aos interesses da iniciativa privada.

No início do período das concessões, as atividades delegadas eram via de regra atividades econômicas que envolviam vultosos investimentos, tais como transporte público ferroviário, fornecimento de água, gás, eletricidade e transporte coletivo urbano ${ }^{52}$, entre outros. A concessão de serviços públicos, assim, foi aceita e adotada em todos os países civilizados. $^{53}$

Essa estrutura inicial das concessões de serviço público, entretanto, não permaneceu assim por muito tempo. O concessionário do serviço, que atuava por sua conta e risco, tinha dois tipos de problemas: o primeiro relativo à possibilidade que se reconhecia à Administração Pública de alterar unilateralmente os contratos, sob o fundamento do interesse público. Além disso, o negócio também estava sujeito ao fato do príncipe, isto é, também sujeito às alterações em decorrência das ações do Estado que não tinham relação direta com a concessão, mas que, pela via indireta, também afetavam o seu negócio.

Mas o modelo de delegação de serviços atendia aos interesses do Estado, que dele não pretendia se desfazer, porque a concessão mantinha o benefício de livrar o Estado de contratar e administrar a mão-de-obra para trabalhar nessas atividades específicas. Por essa razão, num primeiro momento, os serviços prestados pelos concessionários não foram retomados pelo Estado, mas, aos poucos, a irresponsabilidade do Estado nas concessões foi se transformando, de forma a torná-lo o primeiro garantidor e fiador da operação, para, em seguida, se inserir na relação contratual, a cláusula da imprevisão ${ }^{54}$. Em razão dessas alterações, surgiu “uma associação lesiva ao Poder Público que, privado de benefícios eventuais, estava, entretanto, obrigado a participar das perdas e da exploração do serviço público concedido". 55

\footnotetext{
${ }^{52}$ MEDAUAR, Odete, Direito administrativo moderno, cit., p. 373.

${ }^{53}$ PINTO, Bilac. O declínio das sociedades de economia mista e o advento das modernas empresas públicas. Revista de Direito Administrativo, Fundação Getulio Vargas, n. 32, p. 3, abr./jun. 1953.

${ }^{54}$ Ibidem, p. 3.

${ }^{55}$ Ibidem, p. 3.
} 
A consequiência foi a perda do interesse pela concessão tanto pelo Estado como pelo concessionário.

Esses fatos levaram ao exaurimento do modelo de concessão, e a alternativa adotada foi a das sociedades de economia mista ${ }^{56}$, através da qual o Poder Público associava-se ao particular para o desempenho de certas atividades, isto é, o Estado, que pelas razões apontadas, antes se retirara da execução dos serviços de forma direta, voltava a prestá-los, agora como sócio de empresas privadas.

Mas as sociedades de economia mista não se mostraram a fórmula perfeita para a solução desses problemas, pois esse tipo de empresa traz em sua concepção um "conflito entre o interesse público e o privado", como anotou Bilac Pinto:

\begin{abstract}
"A experiência demonstrou que esta associação entre o Estado e os particulares não pode, senão excepcionalmente, conduzir a bons resultados. Uma associação não beneficia a todos os associados senão quando eles visem a um fim comum, ou, pelo menos, a fins análogos, excluída a oposição entre uns e outros. (...) ora, em uma empresa de economia mista, os fins visados pelo Estado e pelos particulares são diametralmente opostos: eles se excluem reciprocamente. ${ }^{, 57}$
\end{abstract}

No mesmo sentido, Edmir Netto de Araújo, analisando o declínio das sociedades de economia mista e o surgimento das empresas públicas, justifica esse movimento como sendo decorrência da "irresistibilidade da publicização econômica decretada pela incompatibilidade filosófica já mencionada, dos interesses do Estado e do particular, conduzindo as Administrações das economias libero-sociais do mundo ocidental a tão alto grau de intervencionismo que já mereceu o epíteto de "capitalismo de Estado". 58

\footnotetext{
${ }^{56}$ PINTO, Bilac, O declínio das sociedades de economia mista e o advento das modernas empresas públicas, cit., p. 3.

${ }^{57}$ Interessante notar que esse mesmo tipo de conflito pode ser encontrado na concessão. A concessão de prestação de um serviço público a terceiros, feito a empresas particulares e mesmo a empresas estatais que atuem sob o regime de direito privado, põe em constante conflito duas idéias "antitéticas": de um lado, quando o Estado concede os serviços está interessado no atendimento do interesse público que, assim, estará atendido com a própria execução dos contratos. Ademais, à Administração interessa exercer a autoridade sobre o contrato. De outro lado, o particular, quando executa os serviços públicos, está em busca do lucro e, nesse sentido, à vista do particular, o interesse público fica em segundo plano. A necessidade desta conciliação domina o regime de concessão. (RIVERO, Jean. Droit administratif. 4. ed. Paris: Dalloz, 1970. p. 410.

${ }^{58}$ ARAÚJO, Edmir Netto de, Curso de direito administrativo, cit., p. 229.
} 
Após o declínio das sociedades de economia mista, o modelo adotado foi o de empresa pública. As empresas públicas, segundo Edmir Netto de Araújo, são "sociedades de um só membro que surgiram no Brasil, não só para corrigir desequilíbrios, mas para participar efetivamente da economia, como qualquer particular". 59

A partir das últimas décadas do século XX, contudo, o interesse pela concessão foi retomado, ganhando força a delegação da execução dos serviços públicos aos particulares, justificada pela idéia de privatização, com objetivo de "devolver à iniciativa privada um espaço que, em situação de normalidade, a ela compete, retornando o Estado às suas funções típicas, especialmente no que concerne ao essencial, como saúde pública, segurança, educação e saneamento". ${ }^{60}$

No Brasil, a Constituição Federal de 1988 já dividiu os espaços públicos e privados e, como já se disse, a atuação no campo econômico do Estado ficou limitada a determinadas situações (art. 173) excepcionais, pois a regra geral é que a atividade econômica fique reservada ao particular.

A partir do comando do artigo 175, foi editada a Lei n. 8.987, de 13.02.1995, que passou a disciplinar as concessões de serviço público ao particular. Além dela, a Lei n. 9.074, de 07.07.1995 e a Lei n. 11.079, de 30.12.2004, a conhecida Lei das Parcerias Público-Privadas são os documentos jurídicos que disciplinam a modalidade.

\subsubsection{A expressão "concessão" e seus significados}

O termo concessão no Brasil é utilizado de diversas formas. Por primeiro, anote-se que a doutrina faz diferença entre duas modalidades de concessão: a concessão translativa, através da qual o poder concedente transfere ao concessionário prerrogativas das quais é titular, como no caso do serviço público e da obra pública, e a concessão constitutiva, em que há autorização de utilização privativa de bem público.

\footnotetext{
${ }^{59}$ ARAÚJO, Edmir Netto de, Curso de direito administrativo, cit., p. 229.

${ }^{60}$ SOUTO, Marcos Jurema Vilella. Desestatização, privatização, concessão, terceirizações e regulação. 4. ed. Rio de Janeiro: Lumen Juris, 2001. p. 24.
} 
Na concessão de serviço público, verbi gratia, são outorgadas ao concessionário algumas prerrogativas como, a título de exemplo, o poder de desapropriação contido no artigo 31, VI, da Lei n. 8.897/97 (promover as desapropriações e constituir servidões autorizadas pelo poder concedente, conforme previsto no edital e no contrato).

Como delegação de serviço público, a expressão é utilizada para designar a concessão de serviços públicos regulada pelas Leis ns. 8.987, de 13.02.1995, e 9.074, de 07.07.1995. Para esses serviços, a expressão concessão é utilizada no sentido tradicional, isto é, como forma de delegação de serviços ao particular que se remunera pela tarifa de serviço cobrada do usuário.

Com essa conotação, a expressão concessão, como forma de delegação de serviço público, é também utilizada em várias outras leis esparsas, com na legislação de telecomunicações, radiodifusão, televisão por assinatura, energia elétrica, portos etc.

A expressão concessão também foi utilizada pela Lei n. 11.079, de 31.12.2004, a Lei das Parcerias Público-Privadas ${ }^{61}$, que instituiu dois novos tipos de concessão no ordenamento jurídico brasileiro: (a) a concessão patrocinada, que é a concessão de serviços públicos, ou de obras públicas, quando envolver, adicionalmente à tarifa cobrada dos usuários, contraprestação pecuniária do parceiro público ao parceiro privado; e (b) a concessão administrativa, que é o contrato de prestação de serviços da qual a Administração Pública seja a usuária direta ou indireta, ainda que envolva execução de obra ou fornecimento e instalação de bens.

Ao criar novas modalidades de concessão de serviço público, essa Lei, todavia, não inova no nosso ordenamento jurídico, uma vez que apenas "amplia a figura da concessão",62. As novas formas são, assim, consideradas modalidades de concessão ou espécies do gênero concessão de serviços públicos.

\footnotetext{
${ }^{61}$ A expressão parceria público-privada também é utilizada por Maria Sylvia Zanella di Pietro como gênero, do qual são espécies todas as formas de parceria que o Poder Público faz com o particular. No sentido que damos a este capítulo, contudo, está a designar as parcerias instituídas pela Lei n. 11.079/2004, as chamadas parcerias público-privadas.

${ }^{62}$ CRETElla NETO, José. Comentários à Lei das Parcerias Público-Privadas - PPPs. Rio de Janeiro: Forense, 2005. p. 11.
} 
Além da utilização da expressão para designar a delegação de serviços públicos, no direito brasileiro também a mesma expressão é adotada para designar outras formas de delegação ao particular que não se referem a serviços públicos, como é o caso da concessão de obras públicas, de uso de bem público e de direito real sobre bem público.

A concessão de obra pública é conceituada no inciso III do artigo $2^{\circ}$ da Lei $n$. 8.987, de 13.02.1995, como uma modalidade de concessão de obra precedida de serviço público, que assim dispõe:

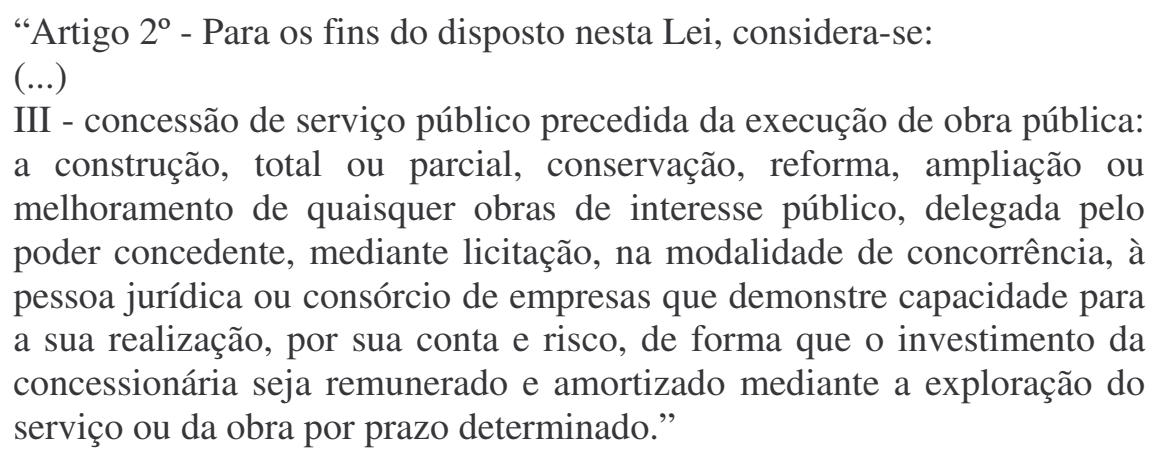

A concessão de obra pública não se confunde com a concessão de serviço público, pois ambas têm objetos distintos ${ }^{63}$. Na concessão de obra pública, em primeiro lugar, o particular executa a obra para, em seguida, recuperar o investimento e remunerar-se mediante a cobrança de tarifas do usuário do serviço. Nesse caso, a concessão de serviço que sobrevém à concessão de obra pública é uma concessão comum, tradicional, que não se diferencia das demais concessões, exceto pelo fato de servir de remuneração a uma obra realizada anteriormente.

A concessão de uso é utilizada pelo Poder Público para instrumentalizar o uso privativo de bens imóveis públicos por particulares.

As concessões de uso de bem público diferem das concessões de serviço público quanto ao objeto da relação jurídica, pois enquanto nessas últimas há a delegação de um serviço público, naquelas ocorre apenas a utilização ou a exploração de um bem público. ${ }^{64}$

\footnotetext{
${ }^{63}$ ARAÚJO, Edmir Netto de, Curso de direito administrativo, cit., p. 156.

${ }^{64}$ Ibidem, p. 701.
} 
A concessão de direito real de uso, instituída pelo Decreto-Lei n. 271, de 28.02.1967, atribuiu o uso de bem público como direito real intransferível a terceiros por atos inter vivos, por sucessão legítima ou testamentária. É isso que a distingue da concessão administrativa de uso. ${ }^{65}$

Como preleciona Diogo de Figueiredo Moreira Neto:

\begin{abstract}
"A concessão de direito real de uso de bem público é outra espécie contratual de transferência de utilização de um domínio público fundiário a um particular, em caráter extraordinário e exclusivo, geradora de um direito real resolúvel e transferível, para que dele se utilize especificamente para fins de urbanização, industrialização, edificação, cultivo ou outra finalidade de interesse social, a título gratuito ou oneroso, e não necessariamente precedido de licitação (v. art. $1^{\circ}$ da Lei 8.666, de 21 de Junho de 1993).".66
\end{abstract}

Os direitos reais podem ser definidos a partir de sua distinção dos direitos obrigacionais. Como ensina Francisco Eduardo Loureiro: "Também chamados de iura in $r e$, traduzem uma dominação sobre a coisa e constituem importante categoria jurídica, que se diferencia do direito das obrigações (iura ad rem) pelo fato de se traduzir na faculdade

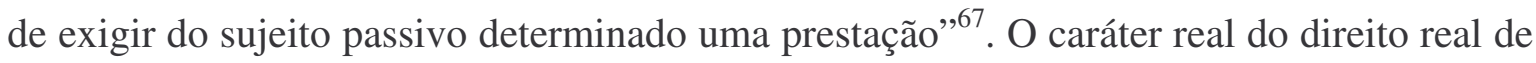
uso enfatiza esta relação jurídica, que dá ao detentor o direito de seqüela.

Como se vê, há diversas acepções de concessão admitidas em direito e que não se confundem com a examinada neste trabalho, que é a concessão de serviços públicos.

\title{
3.1.1.3. A natureza jurídica da concessão
}

A concessão de serviço público reúne, em uma só relação jurídica, o Estado e um particular. Essa relação jurídica, por envolver o Estado e o particular, leva a diferentes concepções da natureza jurídica da concessão.

\footnotetext{
${ }^{65}$ MEIRELLES, Hely Lopes. Direito administrativo. 20. ed. São Paulo. Malheiros, 2005. p. 441.

${ }^{66}$ MOREIRA NETO, Diogo de Figueiredo. Curso de direito administrativo. 14. ed. Rio de Janeiro: Forense, 2006. p. 353.

${ }^{67}$ LOUREIRO, Francisco Eduardo. Código Civil comentado: doutrina e jurisprudência. In: PELUSO, Cezar. (Org.). Código Civil comentado: doutrina e jurisprudência. 2. ed. São Paulo: Manole, 2008. p. 1.077.
} 
Sob a ótica do Estado, a concessão é um instrumento que lhe permite realizar o interesse público na execução de um serviço público, tal qual definido pela lei. Já sob a ótica do particular, a concessão é um contrato que lhe permite prestar um serviço, que será remunerado e, portanto, sobre o qual apurará lucro.

Essas diferentes perspectivas do mesmo negócio ${ }^{68}$ caracterizam a concessão, e daí decorrem diversas conseqüências.

A primeira delas é o surgimento de várias explicações sobre a natureza jurídica das concessões, como sintetiza Mário Mazagão: concessão como ato unilateral, como dois atos unilaterais, como contrato de direito privado, como contrato de direito público, como contrato de direito público e privado e como contrato de natureza mista. ${ }^{69}$

Atualmente, contudo, predominam três correntes: (a) teorias unilaterais; (b) teorias contratuais e; (c) teorias mistas. ${ }^{70}$

As teorias unilaterais consideram as concessões como atos isolados - um ato da própria Administração e outro do concessionário - e autônomos. De acordo com essa teoria, o objeto da concessão está fora do comércio e não pode ser delegado através de um contrato. Pelas teorias contratuais, a concessão é um contrato público para alguns e privado para outros e, finalmente, para a teoria mista, a concessão é mais que apenas um ato, pois é um conjunto de comportamentos administrativos, aperfeiçoados por um ato administrativo unilateral, seguido de um contrato.

Para Celso Antonio Bandeira de Mello, há uma "relação jurídica complexa"71, composta de dois atos unilaterais e um contrato. Os atos unilaterais são: (a) o ato através do qual o Estado fixa unilateralmente condições de funcionamento, organização e modo de prestação de serviços; e (b) um ato-condição, por meio do qual o concessionário voluntariamente adere ao contrato. Além desses dois atos unilaterais, há um contrato que tem o objetivo de garantir a equação econômico-financeira.

\footnotetext{
${ }^{68}$ DI PIETRO, Maria Sylvia Zanella, Parcerias na administração pública, cit., p. 93.

69 Sobre teses sobre a natureza jurídica da concessão ver: MASAGÃO, Mário. Natureza jurídica da concessão de serviço público. São Paulo: Saraiva, 1933.

${ }^{70}$ ROCHA, Cármen Lúcia Antunes, Estudo sobre concessão e permissão de serviço público no direito brasileiro, cit., p. 34.

${ }^{71}$ BANDEIRA DE MELLO, Celso Antonio, Curso de direito administrativo, cit., p. 696.
} 
Segundo o autor, então, a delegação de serviços públicos se caracterizaria por uma "adesão" do concessionário aos termos impostos pelo Poder Público, mais a cláusula de equilíbrio econômico-financeiro do contrato. A adesão às cláusulas impostas pela Administração Pública impede que a concessão tenha a natureza meramente contratual, porquanto esta pressupõe a possibilidade de as partes estarem em situações iguais, o que não acontece no contrato de adesão, em que uma parte simplesmente adere às condições impostas pela outra parte. Ora, o contrato de adesão não respeita o princípio da autonomia da vontade, segundo o qual há "ampla liberdade contratual, no poder dos contratantes de disciplinar os seus interesses mediante acordo de vontades, suscitando efeitos tutelados pela ordem jurídica". ${ }^{72}$

No mesmo sentido, Jean Rivero ${ }^{73}$ leciona que o ato da concessão no século XIX foi considerado integralmente um contrato. Com o desenvolvimento da teoria do serviço público, fixou-se a sua natureza e a jurisprudência e doutrina revisaram essa teoria, consagrando o princípio da dupla natureza do ato de concessão: a concessão constitui uma junção de cláusulas regulamentares e de uma parte contratual, em que se disciplinam as disposições financeiras que garantem a remuneração ao concessionário, e que são dominadas pelo princípio fundamental dos contratos administrativos, que é o do equilíbrio econômico financeiro do contrato.

A doutrina moderna, contudo, relativiza a autonomia da vontade contratual, ao argumento de que a liberdade de contratar sofre limitações em seus três aspectos: na faculdade de contratar e não contratar; na liberdade de escolha do outro contraente; e no poder de estabelecer o conteúdo do contrato. ${ }^{74}$

No mesmo sentido, Edmir Netto de Araújo ensina que "liberdade de discussão das cláusulas, por exemplo, não é elemento essencial para a caracterização do contrato, pois, na atualidade, essa liberdade, decorrente do princípio da autonomia da vontade, é entendida como liberdade de aceitação das estipulações". 75

\footnotetext{
${ }^{72}$ BANDEIRA DE MELLO, Celso Antonio, Curso de direito administrativo, cit., p. 696.

${ }^{73}$ RIVERO, Jean, Droit administratif, cit., p. 411.

${ }^{74}$ GONÇALVES, Carlos Roberto. Direito civil brasileiro. São Paulo: Saraiva, 2004. p. 22. v. 3.

${ }^{75}$ ARAÚJO, Edmir Netto de, Curso de direito administrativo, cit., p. 623.
} 
E parece que é assim mesmo. Os contratos de adesão são plenamente aceitos pela doutrina civilista como contratos, e não como atos unilaterais, inclusive pela legislação brasileira (arts. 423 do CC e 54 do CDC).

Como explica Nelson Nery Junior, "o contrato de adesão não encerra novo tipo contratual ou categoria autônoma de contrato, mas somente técnica de formação de contrato, que pode ser aplicada a qualquer categoria ou tipo contratual, sempre que buscada a rapidez na conclusão do negócio, exigência das economias em escala". ${ }^{76}$

Nos contratos administrativos em geral e no contrato de concessão em especial, estão presentes as "cláusulas regulamentares" 77 , que são previstas na lei que disciplina o serviço público. Entretanto, o fato dessas cláusulas necessariamente constarem dos contratos não suprime a natureza contratual da concessão porque, tal como nos contratos de adesão, as cláusulas regulamentares não são suficientes para tornar o ato unilateral, e ainda porque nessa relação há outras cláusulas contratuais, como, por exemplo, a cláusula do equilíbrio econômico financeiro, que tornam a relação bilateral equilibrada.

Outro ponto que usualmente é questionado na teoria contratual da concessão referese ao poder de a Administração Pública alterar unilateralmente as cláusulas do contrato. $\mathrm{O}$ fato de uma das partes alterar unilateralmente uma relação contratual descaracterizaria a concessão como um contrato. Também aqui vale a lição de Edmir Netto de Araújo, para quem o poder de alteração unilateral do contrato "não tem a extensão que apresenta", pois a relação formada se equilibra com o direito ao equilíbrio econômico-financeiro do contrato, o que preserva a natureza sinalagmática e comutativa do mesmo, e, ademais, "não são todas as cláusulas que podem ser alteradas, mas apenas aquelas chamadas regulamentares ou de serviço, pois as cláusulas financeiras são inalteráveis, salvo acordo entre as partes". 78

O princípio da inalterabilidade de cláusulas contratuais tem sido mitigado nos contratos realizados no direito civil, que durante muito tempo se fundamentaram no

\footnotetext{
${ }^{76}$ NERY JÚNIOR, Nelson et al. Código Brasileiro de Defesa do Consumidor comentado pelos autores do Anteprojeto. 7. ed. Rio de Janeiro: Forense Universitária, 2001. p. 566.

${ }_{77}^{77}$ DI PIETRO, Maria Sylvia Zanella, Parcerias na administração pública, cit., p. 95.

${ }^{78}$ ARAÚJO, Edmir Netto de, Curso de direito administrativo, cit., p. 624.
} 
princípio do pacta sunt servanda. Como observa Carlos Alberto Gonçalves: “o princípio da conservação dos contratos, ante a nova realidade legal, deve ser interpretado no sentido de sua manutenção e continuidade da execução, observadas as regras da boa fé objetiva e da função social do contrato. Falar-se em pacta sunt servanda com a conformação e o perfil que lhe foram dados pelo liberalismo dos séculos XVIII e XIX é, no mínimo, desconhecer o que ocorreu no mundo, do ponto de vista social, político, econômico e jurídico nos últimos duzentos anos". 79

É possível dizer, com apoio nessa doutrina, que mesmo nos contratos privados, há “cláusulas regulamentares", com origem no princípio de ordem pública, que mitigam a liberdade de contratar e a obrigatoriedade de cumprimento do contrato, inclusive o cumprimento até o seu termo, como ocorre nos casos das cláusulas rebus sic stantibus (arts. 478 a 480 do CC), da lesão (art. 157 do CC) e do estado de perigo (art. 156 do CC).

Há casos em que nem mesmo é preciso a existência qualquer cláusula citada para se concluir pela possibilidade de extinção unilateral do contrato. Um exemplo disso pode ser encontrado no direito do fiador de se exonerar das obrigações da fiança mediante simples notificação ao locador $^{80}$, isto é, o fiador altera unilateralmente a sua obrigação, simplesmente mediante uma notificação.

Além disso, argumenta-se contra a natureza jurídica contratual da concessão, sob a alegação de que, no contrato celebrado com base na lei civil, as partes podem livremente sair da relação contratual, o que não ocorreria nos contratos administrativos. Ocorre, contudo, que essa não é uma regra absoluta para os contratos civis, já que há exemplos em que também existem limitações para as partes rescindirem o contrato, como nos contratos de locação, que não podem ser rescindidos pelo locador antes do seu término (art. $4^{\circ}$. da Lei n. 8.425/93).

Tudo indica, portanto, que as razões que levaram parte da doutrina a entender não haver entre concessionário e concedente uma relação contratual, a partir de uma comparação com o contrato civil, não se sustenta.

\footnotetext{
${ }^{79}$ GONÇALVES, Carlos Roberto, Direito civil brasileiro, cit., p. 29.

${ }^{80}$ ARAÚJO, Edmir Netto de, Curso de direito administrativo, cit, p. 624.
} 
Em suma, a concessão de serviços públicos tem a natureza de uma relação contratual, ainda que sui generis, porque segue especificações próprias.

\subsubsection{A concessão de serviço público e o contrato de locação de serviços}

Cabe ainda distinguir o contrato de concessão de serviço público do contrato de prestação de serviços administrativos, também chamado de contrato de locação de serviços disciplinado pela Lei n. 8.666/93.

Os contratos de prestação de serviços administrativos não são contratos de concessão porque não envolvem a concessão de serviços públicos nem a prestação direta de serviços aos usuários.

No contrato de concessão de serviço público, há uma delegação apenas da execução dos serviços aos particulares, uma vez que a titularidade dos serviços permanece em mãos do Poder Público, e o concedente mantém a relação jurídica com o usuário. Diferente dessa situação é aquela do contrato administrativo de prestação de serviços, em que o prestador é simples executor material para o Poder Público contratante e a relação jurídica de prestação de serviços é formada entre o usuário e o Poder Público, e não com o executor dos serviços.

Os prestadores de serviços são as pessoas jurídicas de direito privado que executam serviços para a Administração Pública, sob o regime da Lei n. 8.666/93, e não diretamente para os usuários dos serviços, embora em algumas situações seja possível haver o contato direto do prestador com o usuário do serviço. Exemplos de locação de serviços são os contratos de prestação de serviços de transporte funcionários, ou a contratação do serviço de pintura das paredes de um imóvel público, ou até mesmo a contratação de advogados para determinados casos.

As diferenças entre os contratos de concessão e de prestação de serviços administrativos são relativas ao objeto dos contratos, à forma de remuneração, às 
prerrogativas públicas e ao poder de intervenção do Poder Público nos contratos de concessão. $^{81}$

A primeira distinção se refere ao objeto. O objeto do contrato de concessão é a delegação de serviços públicos, envolvendo tanto a gestão como a execução material dos serviços públicos. A execução do serviço é transferida em sua inteireza ao particular, que passa a executá-lo por conta própria e com domínio integral da prestação dos serviços.

Na locação de serviços, o objeto é a contratação de terceiros para a prestação de uma determinada atividade, que não é atribuída ao Estado como serviço público, mas como exercício de suas competências administrativas internas comuns ou ordinárias. O locador dos serviços não tem o domínio integral de gestão dos serviços porque é contratado para executar aquilo que lhe é pedido pelo órgão da Administração Pública.

Assim, são diferentes os objetos, pois enquanto no contrato de concessão de serviços públicos o Poder Público delega o serviço para que o particular o execute sob o regime de serviço público, na locação de serviços, o objeto é apenas a contratação dos serviços por parte do Poder Público para que execute tarefas administrativas ordinárias.

Outra diferença diz respeito à forma de remuneração dos serviços contratados. No contrato de concessão, a tarifa que é paga pelo usuário é receita direta do concessionário, o que, dessa forma, se constitui em um dos elementos do contrato de concessão; ao contrário, no contrato de prestação ou locação de serviços administrativos, a remuneração do prestador de serviços vem do Estado, para quem os serviços são prestados, e que é o usuário desses serviços.

É bem verdade que a Lei das Parcerias Público-Privadas (Lei n. 11.079/2004), alterou esse panorama, porque passou a admitir a remuneração feita diretamente pelo Estado ao concessionário do serviço público.

Mesmo assim, mantém-se a diferença entre os dois contratos, uma vez que a remuneração paga ao concessionário pelo Estado, no caso concessão realizada na forma da

\footnotetext{
${ }^{81}$ DI PIETRO, Maria Sylvia Zanella, Parcerias na administração pública, cit., p. 241.
} 
parceira público-privada, é complementar à percebida pelo concessionário, e não tem a mesma natureza da remuneração na locação de serviços.

Na concessão de serviços públicos realizada sob o fundamento das parcerias público-privadas, na modalidade "concessão administrativa", não haverá pagamento de tarifas pelo usuário e a remuneração do concessionário será feita apenas pela receita faturada do Poder Público concedente. Nesses casos, porém, como se verá adiante, a opção do Poder Público em remunerar diretamente o concessionário pode ter razões outras, como, por exemplo, a opção de política estatal de não cobrar tarifas pela prestação de determinados serviços. O exemplo da doutrina é a da exploração de uma estrada de rodagem sem a cobrança de pedágio. Nesse caso, apesar de o Poder Público pagar diretamente ao concessionário de serviço de forma igual ao que faz ao locador, a remuneração feita ao concessionário justifica-se por razões de política pública, mas no caso da locação de serviços, o pagamento que é realizado ao locador é remuneração por serviços prestados à Administração Pública.

Com relação às prerrogativas, o contrato de concessão de serviços públicos transfere aos concessionários prerrogativas próprias da Administração Pública, como, por exemplo, as previstas no artigo 31 da Lei n. 8.987/95, de promover desapropriações e constituir servidões autorizadas pelo poder concedente, de exercer o poder de polícia, de captar, aplicar e gerir os recursos financeiros necessários à prestação dos serviços, entre outras. No contrato de locação de serviços, não há nenhuma prerrogativa pública que é transferida ao particular, que age em nome e sob a tutela da Administração Pública.

Finalmente, na concessão, o Poder Público tem o poder de intervir na empresa concessionária em caso de descumprimento das cláusulas contratuais, algo inexistente no contrato de locação de serviços.

Nos contratos de locação de serviços, a Administração Pública poderá, no máximo, utilizar as prerrogativas das cláusulas exorbitantes, derrogatórias, próprias dos contratos em que a Administração Pública é parte. 


\subsubsection{Características e conceito de concessão de serviço público}

A adoção de um conceito de concessão de serviço público pressupõe a análise prévia de suas características e seus elementos constitutivos, que é o tema deste item.

Como já se viu, a concessão de serviço público tem a natureza de um contrato celebrado entre a Administração Pública e o concessionário interessado na prestação dos serviços.

Mas a relação contratual que se estabelece entre a concedente e o concessionário extrapola para além da relação das partes e vai influir na esfera de direitos de uma terceira pessoa que, embora não seja parte no contrato de concessão, será beneficiário desse negócio jurídico, que é o usuário dos serviços concedidos, dando à concessão "efeitos trilaterais". 82

Assim é que a concessão de serviços públicos envolve três partes: de um lado, a Administração Pública, que é a titular do serviço que será delegado, de outro lado a empresa ou ente privado que está executando os serviços e, finalmente, os consumidores dos serviços públicos

A participação dessas três partes na concessão de serviços públicos e a forma de compor esses três interesses é que dá à concessão de serviços públicos características próprias.

Para a Administração Pública, importam os serviços que virão a ser executados e o seu atendimento ao administrado. Além disso, em se tratando de um contrato em que uma das partes é a Administração Pública, a relação contratual receberá, além dos elementos necessários e caracterizadores do contrato de concessão, os relativos aos contratos administrativos, originários da supremacia da ordem pública sobre o particular, as chamadas cláusulas exorbitantes, explícitas ou implícitas, que existem em todos os contratos administrativos

\footnotetext{
${ }^{82}$ DI PIETRO, Maria Sylvia Zanella, Parcerias na administração pública, cit., p. 111.
} 
O executor dos serviços é uma pessoa jurídica de direito privado. A sua presença na relação de concessão importa em dois efeitos: (a) introduzir na relação jurídica de concessão uma cláusula contratual de equilíbrio econômico-financeiro; e (b) tornar contratual a relação entre as partes.

Há, por fim, o usuário dos serviços, beneficiário do contrato que, embora não seja parte, é atingido pelos efeitos do contrato. Os usuários dos serviços públicos concedidos têm direito ao recebimento de uma prestação de serviços adequada, prestada com cortesia, eficiência, modicidade da tarifa, universalidade, regularidade e continuidade.

O atendimento ao interesse público, o fato de a prestação de serviço ser realizada por pessoa privada e os interesses visados pelo particular permitem arrolar, sob tais óticas, as principais características da concessão de serviço público.

Assim, sob a ótica da Administração, as características são as seguintes: poderes exorbitantes da Administração Pública para o controle e fiscalização do interesse público; responsabilização objetiva das concessionárias por danos causados a terceiros; e reversão dos bens da concessionária afetados à prestação dos serviços.

Sob a ótica da pessoa jurídica de direito privado presente na concessão, a principal característica é o equilíbrio econômico-financeiro do contrato.

E sob o ótica do usuário, as características da concessão são: recebimento de uma prestação de serviços adequada, prestada com cortesia, eficiência, modicidade, universalidade, regularidade e continuidade; a sujeição do concessionário aos princípios inerentes à prestação de serviços públicos: continuidade, imutabilidade e igualdade dos usuários.

\subsection{Concessão de serviço público e presença da Administração Pública como contratante: poderes exorbitantes}

A Administração Pública contratante da concessionária publiciza a relação jurídica que se estabelece entre as partes. O contrato celebrado entre as partes é um contrato de 
direito público com características específicas e, portanto, há cláusulas exorbitantes que dão alguns poderes à Administração Pública que não existem em relações contratuais civis. A Administração Pública exerce, assim, vários tipos de poderes extravagantes, exorbitantes.

A publicização da relação também influi na relação do concessionário com o terceiro, de modo a tornar objetiva a sua responsabilidade civil, como se fosse o próprio Estado atuando.

A Lei brasileira de concessão (Lei n. 8.987/95) dispõe sobre os poderes da Administração Pública concedente dos serviços públicos e os distribui em vários artigos. $\mathrm{O}$ artigo $29^{83}$ enumera de modo expresso poderes conferidos ao poder concedente, que são, em resumo, os seguintes: (a) poder de fiscalização; (b) poder de alteração unilateral das cláusulas regulamentares; (c) poder de extinguir a concessão antes de findo o prazo inicialmente estatuído; (d) poder de intervenção; e (e) poder de aplicar sanções ao concessionário inadimplente.

Poder de fiscalização: a Administração Pública, como titular dos serviços concedidos, tem o poder-dever de controlar e fiscalizar a execução dos serviços, para que eles sejam mantidos dentro dos padrões necessários ao atendimento público. Assim, o concedente do serviço público é "o fiador de sua regularidade e boa execução perante os usuários". 84

\footnotetext{
83 “Artigo 29 - Incumbe ao poder concedente: I - regulamentar o serviço concedido e fiscalizar permanentemente a sua prestação; II - aplicar as penalidades regulamentares e contratuais; III - intervir na prestação do serviço, nos casos e condições previstos em lei; IV - extinguir a concessão, nos casos previstos nesta Lei e na forma prevista no contrato; V - homologar reajustes e proceder à revisão das tarifas na forma desta Lei, das normas pertinentes e do contrato; VI - cumprir e fazer cumprir as disposições regulamentares do serviço e as cláusulas contratuais da concessão; VII - zelar pela boa qualidade do serviço, receber, apurar e solucionar queixas e reclamações dos usuários, que serão cientificados, em até trinta dias, das providências tomadas; VIII - declarar de utilidade pública os bens necessários à execução do serviço ou obra pública, promovendo as desapropriações, diretamente ou mediante outorga de poderes à concessionária, caso em que será desta a responsabilidade pelas indenizações cabíveis; IX - declarar de necessidade ou utilidade pública, para fins de instituição de servidão administrativa, os bens necessários à execução de serviço ou obra pública, promovendo-a diretamente ou mediante outorga de poderes à concessionária, caso em que será desta a responsabilidade pelas indenizações cabíveis; X - estimular o aumento da qualidade, produtividade, preservação do meio-ambiente e conservação; XI - incentivar a competitividade; e XII - estimular a formação de associações de usuários para defesa de interesses relativos ao serviço."

${ }^{84}$ MEIRELLES, Hely Lopes, Direito administrativo brasileiro, 20. ed., 1990, cit., p. 344.
} 
Na classificação adotada por Alexandre Santos de Aragão ${ }^{85}$, com apoio em Pedro Gonçalves e Licinio Lopes Martins, a fiscalização se desenvolve em três vertentes: (a) técnica, versando sobre os deveres concernentes a gestão em si do serviço, ou seja, sobre os meios técnicos, humanos e materiais mobilizados pelo concessionário para gerenciá-lo, que devem ser quantitativa e qualitativamente adequados; (b) financeira, que tem por objeto a higidez financeira da empresa e a aferição do equilíbrio econômico-financeiro da concessão, implicando na análise dos documentos necessários tais como balanços, receitas, despesas, alienações e aquisições de bens etc. Para a concretização do poder de fiscalização, o poder concedente tem direito as informações sobre os dados relativos à administração, contabilidade, recursos técnicos, econômicos e financeiros da concessionária, conforme prevê o artigo 30 da Lei n. 8.987/95; (c) jurídica, que consiste na verificação do cumprimento das obrigações da concessionária com terceiros, especialmente os usuários do serviço, mediante o exame de atos da concessionária sujeitos à aprovação do poder concedente (ex: aprovação de mudanças na estrutura societária da empresa, de reajustes das suas tarifas etc.).

Ao permitir acesso a esses dados e informações, a lei torna efetiva e concreta a fiscalização dos serviços a ser realizada pelo poder concedente. O acesso a essas informações tem dupla conotação: de um lado, constitui um direito do poder concedente; de outro, é dever ou encargo da concessionária, que é obrigada a "permitir aos encarregados da fiscalização livre acesso, em qualquer época, às obras, aos equipamentos e às instalações integrantes do serviço, bem como a seus registros contábeis", conforme dispõe o inciso V do artigo 30 da Lei n. 8.987/95.

A fiscalização deve se estender às instalações, equipamentos, métodos e práticas de execução dos serviços, conforme também alude o inciso VII do artigo 23 da Lei em exame.

A Administração Pública concedente pode contar com o apoio de órgão técnico ou de entidade conveniada para a fiscalização.

O controle do concessionário também será feito pelo usuário dos serviços públicos. A Constituição Federal de 1988 prevê a participação do usuário na relação de concessão,

${ }^{85}$ ARAGÃO, Alexandre Santos de, Direito dos serviços públicos, cit., p. 588. 
assim como nos serviços públicos em geral. O parágrafo $3^{\circ}$ do artigo 37 da Carta Magna, com redação da Emenda Constitucional n. 19/98, inclui o usuário como partícipe atuante da Administração Pública direta e indireta, garantindo-lhe a possibilidade de apresentar reclamações relativas à prestação dos serviços públicos em geral e de realizar o controle dos serviços prestados.

Em obediência ao comando constitucional, a Lei n. 8.987/95 regulamentou a cooperação dos usuários no controle e a fiscalização dos serviços concedidos (art. $3^{\circ}$ ) e estipulou como incumbência do Poder Público estimular a formação de associações de usuários para defesa de interesses relativos ao serviço (inc. XII do art. 29).

Com todas essas disposições, o usuário dos serviços públicos tem, ao lado do poder concedente, uma atuação de cooperação ativa no controle da prestação dos serviços públicos pelos concessionários.

Além da fiscalização direta da concessionária, o Poder Público também regula as suas atividades através das agencias reguladoras, que estabelecem normas de atuação dos concessionários dos serviços públicos.

As agências reguladoras, instituídas no Brasil como autarquias sob regime especial $^{86}$, foram criadas com a finalidade de regulamentação, controle e fiscalização dos serviços concedidos, permitidos ou autorizados.

Várias agências foram instituídas no Brasil após a regulamentação da lei. São exemplos a Agência Nacional de Telecomunicações (Anatel), a Agência Nacional de Vigilância Sanitária (Anvisa) e a Agência Nacional da Aviação Civil (Anac), com poderes de regulação e fiscalização das atividades que a elas foram submetidas.

Poder de alteração unilateral das cláusulas regulamentares: a Administração Pública detém genericamente o poder de alteração das cláusulas regulamentares de

\footnotetext{
${ }^{86}$ De acordo com Hely Lopes Meirelles, o regime especial é o conjunto de privilégios específicos que a lei outorga à entidade para a consecução de seus fins. Esses privilégios caracterizam-se basicamente pela independência administrativa, fundamentada na estabilidade de seus dirigentes (mandato fixo), autonomia financeira (renda própria e liberdade de sua aplicação) e poder normativo (regulamentação da matéria de sua competência) (Direito administrativo brasileiro. 27. ed. São Paulo: Malheiros, 2002. p. 340).
} 
contratos. Tal poder resulta do legítimo exercício de sua posição de supremacia nas relações contratuais de que faz parte.

De acordo com Jean Rivero, esse poder de alteração unilateral das cláusulas pela Administração Pública tem origem em jurisprudencial: No primeiro caso, as concessionárias de luz a gás tiveram que se adaptar ao aparecimento da eletricidade, mas a teoria da alteração unilateral dos contratos foi definitivamente formulada para um concessionário de bondes, em 1907, quando foi necessário aumentar as linhas. Trata-se do arrêt de 5 de dezembro de 1907 da Compaigne Génerale Française des Tramways. ${ }^{87}$

No Brasil, o poder de modificar unilateralmente as cláusulas contratuais já estava previsto no artigo 65, I, da Lei n. 8.666/93. Essa lei permite à Administração Pública alterar unilateralmente qualquer contrato que vier a ser celebrado com o Estado, em caso de modificação inserida no projeto ou nas suas especificações, para melhor adequação técnica aos seus objetivos, ou quando necessária a modificação do valor contratual, em decorrência de acréscimo ou diminuição quantitativa de seu objeto.

Trata-se de um extraordinário poder colocado à disposição da Administração Pública. Em contrapartida, a cláusula do chamado equilíbrio econômico-financeiro que rege tais relações contratuais permite ao particular que encontre o seu equilíbrio, com base em dispositivo legal que assegura o ressarcimento por desequilíbrio econômico do contrato provocado pela Administração Pública.

A Lei de Concessão não previu expressamente que o poder concedente possa alterar unilateralmente os contratos. Não obstante, várias disposições legais nela contidas admitem a existência de prerrogativas relativas a essa matéria.

Assim, o parágrafo $4^{\circ}$ do artigo $9^{\circ}$ da Lei n. 8.987/95 fixa de modo expresso a alterabilidade unilateral do contrato de concessão, quando disciplina a política tarifária, ao estabelecer: "Em havendo alteração unilateral do contrato que afete o seu inicial equilíbrio econômico-financeiro, o poder concedente deverá restabelecê-lo, concomitantemente à alteração."

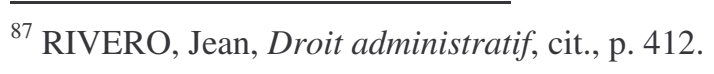


Neste sentido, a lição de Marçal Justen Filho ${ }^{88}$ quando observa: "Produz-se uma espécie de conversão do conteúdo do interesse sacrificado, assegurando-se a integridade patrimonial privada. Em última análise, é vedado ao Estado apropriar-se de bens privados ou destruir os interesses dos particulares, sem uma contrapartida equivalente patrimonialmente".

O poder unilateral de alteração das cláusulas contratuais para modificação do contrato e de sua estrutura, dentro dos limites ditados pela cláusula do equilíbrio econômico-financeiro dos contratos, ainda que não estivesse expressamente previsto na lei específica, deveria ser considerado como inerente à Administração, vale dizer, implícito. Tal consideração, na verdade, decorre da própria natureza da concessão de serviços públicos, que existe como resposta para o atendimento do interesse público, fundamento que é o verdadeiro condutor da atuação estatal nesses contratos. ${ }^{89}$

De qualquer forma, o poder unilateral de alterar as cláusulas contratuais conferido à Administração Pública não implica poder alterar o objeto da concessão e as relações econômicas entre Administração e contratado ${ }^{90}$, pois isto significaria alterar toda a estrutura do contrato e, além disso, poderia vir a ser caracterizada uma forma de burlar a licitação anteriormente feita e, com isso, ferir o direito de terceiros que também competiram no certame.

\section{Poder de extinguir a concessão antes de findo o prazo inicialmente estatuído:} tendo em vista o princípio do interesse público que norteia a ação do Poder Público, impõe-se reconhecer que a Administração Pública tem a faculdade de extinguir a relação de concessão antes do fim do prazo contratual, se o interesse público assim o requerer.

A mesma regra que permite alterar unilateralmente o contrato, vale dizer, o princípio da supremacia do interesse público, é que fundamenta o poder de rescindir o contrato de concessão antes de seu termo.

\footnotetext{
88 JUSTEN FILHO, Marçal. Teoria geral das concessões de serviço público. São Paulo: Dialética, 2003. p. 167.

${ }^{89}$ BANDEIRA DE MELLO, Celso Antonio, Curso de direito administrativo, cit., p. 715.

${ }^{90}$ Ver JUSTEN FILHO, Marçal, op. cit., p. 165.
} 
A Lei n. 8.987/95, em seu artigo 37, previu expressamente essa possibilidade, que é denominada de encampação, e definida como sendo a "retomada do serviço pelo poder concedente durante o prazo da concessão, por motivo de interesse público, mediante lei autorizativa específica e após prévio pagamento da indenização, na forma do artigo anterior".

Há várias condições impostas ao Poder Público para o exercício da encampação, das quais a mais relevante é a exigência de uma lei autorizativa. A necessidade de lei específica se justifica porque protege o concessionário de abusos do poder concedente.

Além da necessidade de existência de uma lei específica, é necessário que o concessionário seja indenizado. A indenização, de acordo com a Lei n. 8.987/95, será a das "parcelas dos investimentos vinculados a bens reversíveis, ainda não amortizados ou depreciados, que tenham sido realizados com o objetivo de garantir a continuidade e atualidade do serviço concedido" (art. 36).

A indenização prevista em lei garante ao concessionário que, na hipótese de o concedente decidir terminar a concessão antes do termo fixado em contrato, haverá a respectiva compensação em virtude da reversão dos bens, isto é, pelas perdas que experimentar nos investimentos que realizou em ativos e que são, ao final da concessão, revertidos ao concessionário, para fins de garantia da continuidade do serviço público retomado.

A lei prevê que a indenização ocorrerá apenas nos casos em que os bens ainda não tenham sido amortizados ou depreciados. Não há uma previsão na lei de indenização por lucros cessantes experimentados pelo concessionário, como, por exemplo, a perspectiva das vantagens do negócio existente por ocasião da contratação com o Poder Público.

O concessionário que se habilita para a prestação de serviço público tem a expectativa de um período de contrato a cumprir e, com base nisso, elabora a sua proposta, da qual o cálculo de investimento em ativos é apenas uma parte.

A omissão da lei, contudo, não implica a impossibilidade de o concessionário ser indenizado por prejuízos decorrentes da interrupção antecipada do prazo contratual. A não- 
indenização, além de ofender o princípio da moralidade, que obriga toda a Administração Pública, também seria um desrespeito à cláusula do equilíbrio econômico-financeiro do contrato de concessão. ${ }^{91}$

Poder de intervenção: o poder concedente pode intervir na concessionária de serviço público se o interesse público assim o requerer. A medida justifica-se quando for necessário "assegurar a continuidade dos serviços, sua normalidade ou o adequado cumprimento das obrigações assumidas pele concessionário” (art. 32 da Lei n. 8.987/95).

O poder de intervenção está implícito no poder de fiscalização para "regularizar o serviço quando estiver sendo prestado deficientemente aos usuários ou ocorrer sua indevida paralisação". ${ }^{2}$

A Lei n. 8.987/95 prevê um prazo de 30 dias para o início do procedimento administrativo instaurado após a decretação da intervenção pelo poder concedente. Nesse procedimento administrativo, que será feito em contraditório, serão investigadas as causas que deram origem à intervenção na concessionária, apurando-se as responsabilidades.

A intervenção destina-se a assegurar o interesse público, mas não tem a função de punir o concessionário, já que está voltada à própria manutenção dos serviços públicos. A punição da concessionária, quando couber, será feita após a conclusão do laudo dos interventores.

Ao final da intervenção, se houver prova de irregularidades, o Poder Público deverá declarar nula a concessão dos serviços públicos e retomar a sua execução. Todo o procedimento administrativo deverá estar concluído no prazo de até 180 dias. A lei comina de invalidade a intervenção, caso não tenha sido terminada nesse prazo.

Poder de aplicar sanções ao concessionário: ao poder concedente cabe também aplicar sanções ao concessionário, conforme prevê genericamente o artigo 29, II da Lei

${ }_{91}^{91}$ BANDEIRA DE MELLO, Celso Antonio, Curso de direito administrativo, cit., p. 730.

92 MEIRELLES, Hely Lopes, Direito administrativo brasileiro, 20. ed.,1990, cit., p. 345. 
$8.987 / 95^{93}$. A falta de um rol legal especificando as situações em que é possível aplicar uma sanção ao concessionário deixa aberto à Administração estipular no edital as ocorrências ou os casos que poderão ser objeto de sanção.

As sanções aplicadas ao concessionário de serviço público são "atos de natureza regulatória"94 emanados de órgãos reguladores de serviços públicos, com base no poder de fiscalização do Poder Público ao constatar uma ação contrária à lei, ao contrato ou ao usuário dos serviços.

Além desses casos, diz Alexandre Santos de Aragão:

"A sanção pode, em tese, alcançar atos em geral que acarretem distorções
no modelo econômico que as atividades reguladoras e reguladas visam,
de acordo com a lei, a preservar. Mas deve, naturalmente, haver previsão,
ainda que genérica, da aplicação das sanções em razão do
descumprimento desses objetivos e standards legais."

Entre as sanções possíveis de aplicação está a rescisão do contrato de concessão, mas, nesse caso, salienta Pedro Gonçalves, é necessário reconhecer a existência da discricionariedade do administrador para rescindir ou não o contrato. Nesse caso, a rescisão deve ser considerada uma "faculdade" da Administração, já que o interesse público pode aconselhar a manutenção do contrato, aplicando-se, na hipótese, outro tipo de sanção. ${ }^{96}$

Nesse mesmo sentido Alexandre Santos de Aragão, para quem os entes reguladores têm margem para deixar de aplicar penalidades ou determinar outras medidas, como, por exemplo, a adoção de termos de ajustamento de condutas, que "suficientes e proporcionais, claramente atendam melhor ao interesse preponderante na atividade regulada". ${ }^{97}$

93 "Artigo 29 - Incumbe ao poder concedente: I - regulamentar o serviço concedido e fiscalizar permanentemente a sua prestação; II - aplicar as penalidades regulamentares e contratuais;"

${ }_{94}^{9}$ ARAGÃO, Alexandre Santos de, Direito dos serviços públicos, cit., p. 594.

${ }^{95}$ Ibidem, mesma página.

96 GONÇALVES, Pedro, A concessão de serviços públicos: uma aplicação da técnica concessória, cit., p. 342.

${ }^{97}$ ARAGÃO, Alexandre Santos de, op. cit., p. 595. 
Os princípios que regem o exercício dos poderes sancionatórios do Estado sobre os delegados de serviço público são: (a) princípio da culpabilidade; (b) princípio da proporcionalidade; (c) principio da segurança jurídica. ${ }^{98}$

Pelo princípio da culpabilidade, é necessário que a conduta do concessionário tenha sido ilegal, contrária à lei ou ao contrato. O princípio da proporcionalidade atua de forma a garantir que a sanção aplicada seja compatível com o ilícito praticado. E, finalmente, o princípio da segurança jurídica garante ao concessionário um comportamento da Administração Pública com base em ações tomadas anteriormente em relação a outras concessionárias, ou mesmo com relação à própria concessionária, seja no sentido de punição, seja no sentido de não-punição. Como observa Aragão, “a principal conseqüência da aplicação dos paradigmas analisados será a nulidade de toda a sanção que a Administração Pública teve diante de outras supostas infrações contratuais análogas, seja do próprio ou de outros concessionários". 99

A responsabilidade objetiva das concessionárias por danos causados a terceiros: a responsabilidade civil das concessionárias de serviço público por danos causados a terceiros, por expressa disposição constitucional (art. 37, § $6^{\circ}$ ) é objetiva, isto é, independente de dolo ou culpa, bastando ao prejudicado demonstrar a relação de causa e efeito para que fique caracterizado o dever de indenizar.

É necessário observar que a regra da responsabilidade objetiva também atinge o Estado de uma forma geral, tal como está previsto no próprio parágrafo $6^{\circ}$ do artigo 37 e no artigo 43 do Código Civil.

Além desses dispositivos legais, também disciplinam a responsabilidade objetiva do concessionário o artigo 12 do Código de Proteção e Defesa do Consumidor (responsabilidade pelo fato do produto e do serviço) e o artigo 927 do Código Civil, que dispõe sobre a responsabilidade objetiva das empresas que atuem em atividades de risco.

\footnotetext{
${ }^{98}$ ARAGÃO, Alexandre Santos de, Direito dos serviços públicos, cit., p. 596.

${ }^{99}$ Ibidem, p. 599.
} 
Não existirá a responsabilidade do Estado, e por decorrência do concessionário, ou, na melhor das hipóteses, será atenuada, quando o concessionário não der causa ao dano, ou quando o ato do concessionário não for a única causa do dano.

São apontadas ainda como excludentes da responsabilidade a força maior, a culpa da vítima, a culpa de terceiro e o estado de necessidade. ${ }^{100}$

A força maior se caracteriza como sendo um acontecimento com origem na natureza, sobre o qual o homem não tem controle e que é imprevisível e inevitável. A força maior possui uma causa conhecida, mas impossível de ser contida pelo homem, é irresistível, inelutável. ${ }^{101}$

Diferentemente da força maior, no caso fortuito, a causa do acidente danoso permanece desconhecida, ignorando-se como foi produzido o evento; refere-se ao próprio funcionamento do serviço, "em especial ao que se chama de acidente mecânico, culpa ignorada do serviço". ${ }^{102}$

A culpa da vítima, como excludente de responsabilidade da concessionária, decorre de uma aplicação lógica do princípio da responsabilidade objetiva, pois, em termos de responsabilidade, a atuação do agente deve ser a causadora do dano, e inexistindo ação do agente, não há como responsabilizá-lo.

Na culpa de terceiro, o raciocínio é semelhante ao da culpa da vítima, uma vez que nele também "a equação dos dados dirigidos à causalidade responsabilizante não chega a se formar". 103

O estado de necessidade, embora admitido por autorizada doutrina, não obstante não parece excluir a responsabilidade do concessionário do serviço público, uma vez que, em algumas ocasiões, o Estado poder gerar danos mesmo atuando em licitude, o que torna um ato aparentemente ilícito em lícito. Nesses casos, a responsabilização do

\footnotetext{
${ }^{100}$ ARAÚJO, Edmir Netto de, Curso de direito administrativo, cit., p. 742.

${ }^{101}$ Ibidem, p. 740.

${ }^{102}$ Ibidem, p. 740.

${ }^{103}$ Ibidem, p. 741.
} 
concessionário tem origem na teoria do risco administrativo ou, no caso, no risco assumido pela prestação dos serviços.

Finalmente, cabe registrar que a responsabilidade do concessionário por atos omissivos, em linha com a responsabilidade do Estado, e conforme doutrina e jurisprudência dominantes ${ }^{104}$, é subjetiva.

\section{A reversão dos bens da concessionária afetados à prestação dos serviços: a} reversibilidade dos bens na concessão de serviço público tem origem no princípio da continuidade dos serviços, uma vez que é através da reversão dos bens que a Administração Pública pode garantir a continuidade dos serviços.

Durante o período de vigência do contrato de concessão, os bens utilizados na prestação dos serviços ficam afetados ao serviço público e são revertidos ao Estado no final do contrato. A reversão dos bens é que faz nascer o direito à indenização.

A reversão dos bens, previstas pelos parágrafos $1^{\circ}, 2^{\circ}$ e $3^{\circ}$ da Lei n. 8.987/95, significa a transferência ao concedente dos bens utilizados pelo concessionário durante a concessão dos serviços públicos.

Com o fim do contrato de concessão, todos os bens afetados à prestação dos serviços revertem ao concedente, para que ele possa, em atendimento à finalidade pública, continuar diretamente a prestação dos serviços se necessário, ou ainda transferir tais bens para um eventual novo concessionário de serviço público, que vier a ser vencedor no certame licitatório.

Após a reversão, os bens passam ao patrimônio do concedente, que deverá deles dispor da forma que melhor atender ao interesse público.

É de se notar que na equação financeira da concessão, o concessionário levará em conta os ativos necessários para a prestação dos serviços concedidos e a sua desvalorização, ou, em termos contábeis, a sua amortização, o que resultará, após alguns

${ }^{104}$ ARAGÃO, Alexandre Santos de, Direito dos serviços públicos, cit., p. 604. 
anos, que os bens terão o valor inferior ao valor inicialmente pago. Todos esses cálculos devem fazer parte da equação financeira inicial e constar da proposta do concessionário, por ocasião da licitação pública para a prestação dos serviços.

Ressalte-se ainda que no contrato de concessão de serviços públicos, a equação do equilíbrio econômico-financeiro do contrato sempre deverá atuar de forma a evitar que a concessão cause um prejuízo ao concessionário. No caso da reversão de bens, se a reversão por algum motivo causar prejuízo ao concessionário, surge o direito ao ressarcimento pelos prejuízos experimentados, na forma da lei.

De acordo com Marçal Justen Filho, há dois métodos de avaliação dos bens que serão revertidos: o método histórico e o método do custo de reprodução que, não raro, geram disputas entre concessionário e poder concedente, ao final da concessão. O primeiro, que é o preferido, considera o valor dos bens no momento de sua aquisição, que será amortizado; pelo segundo método, apura-se o valor dos bens de acordo com o valor necessário para a aquisição dos bens no momento da reversão. O edital de licitação deveria identificar os bens reversíveis, providência que minoraria os problemas da reversão. ${ }^{105}$

Inaplicabilidade da exceptio no adimpleti contractus: a proibição de se argüir a exceção de contrato não cumprido contra a Administração Pública, proibida como regra geral, é enfatizada na concessão de serviços púbicos, cuja prestação deve ser contínua. A Lei n. 8.987/95 previu duas únicas hipóteses de interrupção dos serviços: a interrupção motivada por ordem técnica ou de segurança das instalações e a motivada por inadimplemento do usuário, considerado o interesse da coletividade (art. $6^{\circ}$, § $3^{\circ}$, I e II).

\subsection{Características da concessão, sob a ótica de serem os serviços executados por pessoa jurídica de direito privado}

A participação do concessionário, pessoa jurídica de direito privado, em um dos pólos da relação, gera dois importantes efeitos: a) o direito ao equilíbrio econômico-

${ }^{105}$ JUSTEN FILHO, Marçal, Teoria geral das concessões de serviço público, cit., p. 573. 
financeiro do contrato; e b) a natureza contratual da relação de concessão entre o Poder Público e o concessionário.

A natureza contratual da relação já foi explorada no tópico da natureza jurídica da concessão, e implica na existência de cláusulas específicas ao contrato, como cláusulas financeiras, por exemplo.

Vejamos agora o direito ao equilíbrio econômico-financeiro na concessão.

A delegação dos serviços públicos por meio de concessão impõe a obrigação de equilíbrio no contrato que é celebrado entre as partes. Esse equilíbrio é o mesmo que se espera obter em qualquer contrato, inclusive um contrato entre particulares, regido pelo direito civil. ${ }^{106}$

Quando a obrigação do equilíbrio é transportada para o âmbito de uma relação contratual do Poder Público com o particular, em que há concessão de serviço público, há dois interesses a considerar: a preservação do interesse público e o equilíbrio entre os direitos e obrigações das partes. Um contrato no qual o equilíbrio entre as partes não é protegido provoca um desajuste na prestação dos serviços e, em última análise, o interesse público, que é o objetivo a ser perseguido na concessão, deixa de ser atendido.

A preservação de tais interesses inspirou o surgimento da cláusula do equilíbrio econômico-financeiro do contrato.

O contrato de concessão em sua forma originária era regido pelo direito civil comum, ou seja, pelo direito privado; sob a égide de tal disciplina, colocavam-se as partes - concedente e concessionária - no mesmo plano jurídico, sendo ambos tratados em pé de igualdade perante a lei, segundo as regras do pacta sunt servanda e da lex inter parts ${ }^{107}$; dessa forma, o concessionário executava os serviços públicos por sua conta e risco. Os riscos inicialmente assumidos pelos concessionários deveriam ser suportados da forma

\footnotetext{
${ }^{106} \mathrm{O}$ artigo 478 do Código Civil prevê a possibilidade de resolução por onerosidade excessiva dos contratos de execução continuada ou diferida, se a prestação de uma das partes se tornar excessivamente onerosa, com extrema vantagem para a outra, em virtude de acontecimentos extraordinários e imprevisíveis, ou, ainda, como no artigo 479, a resolução do contrato pode ser evitada se o réu oferecer-se para modificar equitativamente as condições do contrato.

${ }^{107}$ DI PIETRO, Maria Sylvia Zanella, Parcerias na administração pública, cit., p. 114.
} 
pactuada, mesmo que alterações surgissem de forma a alterar o equilíbrio inicialmente estabelecido.

Essa concepção contratual não durou por muito tempo, uma vez que durante a execução do contrato de concessão de serviços públicos se percebeu a necessidade de alterá-lo para atender aos interesses públicos; portanto, os contratos não poderiam ser rígidos, fixos e imutáveis já que tinham como o objetivo atender aos interesses públicos.

Um acórdão do Conselho de Estado francês foi a primeira decisão a considerar a necessidade de que os contratos de concessão não fossem rígidos. Trata-se do arrêt da Compagnie Générale Française des Tramways de $1910 .^{108}$

A contrapartida da possibilidade de alterar os contratos de concessão foi também construção jurisprudencial que garantiu ao concessionário o direito ao equilíbrio econômico-financeiro do contrato.

Segundo Maria Sylvia Zanella Di Pietro, a teoria do equilíbrio econômico baseia-se nos seguintes princípios:

\footnotetext{
"a. princípio da equidade, que impede que uma das partes experimente locupletamento ilícito em detrimento da outra;

b. princípio da razoabilidade, que exige proporção entre o custo e o benefício;

c. o princípio da continuidade do contrato administrativo, que determina a manutenção do equilíbrio econômico-financeiro indispensável para assegurar a continuidade do contrato;

d. o princípio da indisponibilidade do interesse público, pois se o contrato é necessário para atender a alguma necessidade imperiosa da Administração, a esta incumbe assegurar sua continuidade, recompondo o equilíbrio econômico-financeiro do contrato."
}

O necessário equilíbrio econômico-financeiro do contrato de concessão é também fruto da necessidade de evitar que o concessionário fosse prejudicado em razão de ter assumido a obrigação de prestar os serviços públicos, e funda-se, portanto, na presunção de equidade das partes.

\footnotetext{
${ }^{108}$ DI PIETRO, Maria Sylvia Zanella, Parcerias na administração pública, cit., p. 114.

${ }^{109}$ Ibidem, p. 115.
} 
É verdade que as partes não estão em situação de igualdade no contrato de concessão, assim como em qualquer outro contrato administrativo, mas não se admite que o concessionário venha a sofrer prejuízos por razões que não pode controlar.

Jean Rivero leciona que as disposições relativas à remuneração não prevêem o poder de alteração unilateral da Administração. Porém, os elementos contratuais da relação de concessão se manifestam com uma força particular, que é o equilíbrio econômicofinanceiro do contrato, que é uma das características essenciais do contrato administrativo, e a contrapartida das prerrogativas da Administração. ${ }^{110}$

Durante a execução do contrato de concessão, abrem-se ao particular duas perspectivas: a primeira delas é a de perceber lucros decorrentes da exploração da atividade, ou da execução dos serviços públicos. Nela, os direitos do concessionário igualam-se aos de outros empresários, que também estão sujeitos a alterações que possam ocorrer no plano econômico, por vezes passageiras, mas por vezes duradouras, e que, por vezes, podem redundar em prejuízos injustificáveis às partes.

Sendo a concessão considerada uma atividade econômica como qualquer outra, impõe-se levar em consideração tais mudanças na ordem econômica. O concessionário assume os riscos próprios da exploração econômica quando se habilita a prestar os serviços concedidos.

É claro que o concessionário assume os riscos próprios da exploração de atividade econômica, quando se habilita para prestar serviços concedidos. Assim, quando há alterações previsíveis no plano econômico, as chamadas áleas ordinárias, o concessionário não terá o direito a revisão das cláusulas contratuais para recompor o equilíbrio econômico-financeiro do contrato.

As alterações na situação do concessionário que autorizariam um pedido de revisão das cláusulas contratuais, de forma a manter o equilíbrio econômico-financeiro do contrato, são decorrentes de fatos imprevisíveis e não imputáveis ao concessionário, ou da

${ }^{110}$ RIVERO, Jean. Droit administratif, cit., p. 117. 
intervenção do poder concedente nos termos do contrato, e que alterem a situação inaugural de equilíbrio.

É necessário que o concessionário seja colocado em pé de igualdade ao empresário que atua em atividade econômica regular e seja com ele comparado. Contudo, se incorrer em uma administração que leve à ruína o negócio, ou se não tiver capacidade financeira para suportar períodos instáveis, não terá havido nenhuma álea que justifique a alteração das cláusulas do contrato para atender às necessidades da operação empresarial.

Há duas situações em que se dá o desequilíbrio do contrato e que ensejam a revisão das cláusulas contratuais que asseguram o equilíbrio econômico-financeiro do contrato: a ocorrência de fatos imprevistos e a alteração administrativa unilateral do contrato.

Quando o poder concedente atua no contrato de forma a alterar o equilíbrio inicialmente existente, com fundamento no poder de modificação unilateral das cláusulas e das disposições contratuais, acarreta ele uma mudança na condição inicial das partes e que conduz a uma alteração contratual.

Esse tipo de alteração está previsto em diversos dispositivos da Lei n. 8.987/95, como, por exemplo, no artigo $9^{\circ}$, parágrafo $4^{\circ}$, que expressamente determina que "em havendo alteração unilateral do contrato que afete o seu inicial equilíbrio econômicofinanceiro, o poder concedente deverá restabelecê-lo, concomitantemente à alteração".

Além desse, a lei também prevê a possibilidade de modificação do contrato no caso de alteração nos "impostos sobre a renda, a criação, alteração ou extinção de quaisquer tributos ou encargos legais". Trata-se da hipótese de atuação estatal denominada "fato do príncipe", que consiste na utilização de poder por parte do Estado que cause um desequilíbrio contratual, "mas não com base no contrato, mas a outro titulo, como, por exemplo, utilização do poder de polícia". ${ }^{111}$

${ }^{111}$ RIVERO, Jean. Droit administratif, cit., p. 118. 
Para que haja a incidência da teoria da imprevisão, é necessário que o concessionário apresente uma proposta e, após a comprovação do seu impacto no lucro, é possível a revisão da tarifa, para mais ou para menos, conforme o caso.

A inserção dessas cláusulas no Capítulo IV, da política tarifária, da Lei n. 8.987/95, não restringe a aplicação do preceito apenas aos casos de alteração de tarifa, mas a todas as situações que impliquem a alteração unilateral do contrato.

Os fatos imprevisíveis são aqueles que não poderiam ser antevistos ou previstos no momento inicial da elaboração do edital ou da celebração do contrato; trata-se de fatos que não tenham relação com o comportamento das partes e que influenciem substancial e diretamente o contrato de concessão, de forma a ensejar a aplicação da cláusula do equilíbrio econômico-financeiro do contrato.

Para a comprovação da imprevisão, é necessário que as partes demonstrem que, ao tempo da contratação, havia total impossibilidade de anteverem o evento extraordinário que conduziria uma delas à onerosidade excessiva, frustrando a justa expectativa no "êxito do programa contratual". 112

\subsection{A concessão e os usuários do serviço público}

O contrato de concessão de serviços públicos é celebrado entre o poder concedente e o concessionário dos serviços, que é uma pessoa jurídica diferente da pessoa jurídica que concede os serviços. Estabelece-se entre eles uma relação de direito administrativo, regida pelo direito público, que confere ao Poder Público, titular dos serviços, prerrogativas que não existem em outros tipos de contratos.

Uma vez estabelecida a concessão, os serviços serão prestados ao administrado, consumidor e usuário dos serviços públicos e, dessa forma, os efeitos da concessão se

${ }^{112}$ ROSENVALD, Nelson. Código Civil comentado: doutrina e jurisprudência (comentário ao artigo 478). In: PELUSO, Cezar. (Org.). Código Civil comentado: doutrina e jurisprudência. 2. ed. São Paulo: Manole, 2008. p. 469. 
projetam para a esfera dos direitos do administrado, gerando efeitos trilaterais ${ }^{113}$ entre as partes envolvidas.

O administrado integra essa relação quando adere ao contrato de prestação dos serviços e passa a ser sujeito passivo na relação contratual estabelecida com o concessionário.

Quando o usuário dos serviços contrata, por exemplo, uma companhia telefônica, estabelece-se uma relação contratual entre o usuário e a companhia telefônica, que, por sua vez, executa os serviços por delegação do Poder Público. Assim também quando o usuário paga o pedágio nas $\operatorname{estradas}^{114}$, há uma relação contratual entre o usuário e a concessionária que explora a estrada e presta serviços, como, por exemplo, de conservação da estrada.

O usuário dos serviços é, portanto, sujeito de direitos. Em primeiro lugar, tem direito a usufruir os serviços. Além desse direito, atendidas as condições relativas à prestação do serviço e dentro das possibilidades normais dele, ao usuário são garantidos vários outros direitos.

A Constituição de 1988, alargando o conceito de cidadania e atribuindo ênfase especial ao tratamento dos direitos e garantias fundamentais como forma de assegurar a meta fundamental do Estado, que é a realização do interesse público, abre importantes espaços para a participação do cidadão nas atividades de controle e fiscalização do poder, participação que vai além do simples exercício dos direitos políticos ativos, ou direito de voto, usualmente consagrados em nossos textos constitucionais.

Como acentua Roberto Dromi, “o direito subjetivo do usuário 'usar' o serviço, se funda também na obrigação do Estado de tutelar o interesse público e lhe dar satisfação". ${ }^{115}$

\footnotetext{
${ }^{113}$ DI PIETRO, Maria Sylvia Zanella, Parcerias na administração pública, cit., p. 111.

114 Ibidem, p. 112.

${ }^{115}$ DROMI, Roberto. Derecho administrativo. Buenos Aires: Ediciones Ciudad Argentina, 1996. p. 542.
} 
Em correlação com o princípio da dignidade humana, que é princípio fundamental do Estado brasileiro (art. $1^{\circ}$, III, da CF), é possível inferir que há também princípios que enfatizam a dignidade do administrado, do usuário dos serviços prestados pela Administração Pública em geral e, em particular, do usuário dos serviços públicos.

Nesse sentido, o artigo 37 da Constituição Federal - alterado pela Emenda Constitucional n. 19/98 - elevou vários direitos do usuário ao nível da Lei Maior, conduzindo-o ao centro das relações jurídicas na Administração Pública. Assim, quando previu, dentre outras disposições: a sua participação na Administração Pública direta e indireta (art. 37, § $3^{\circ}$ ); assegurou a manutenção dos serviços de atendimento ao usuário e a avaliação periódica, externa e interna, da qualidade dos serviços públicos (art. 37, § $3^{\circ}, \mathrm{I}$ ); assegurou o acesso aos usuários a registros administrativos e a informação sobre atos de governo inciso (art. 37, $\S 3^{\circ}$, II); introduziu a representação do usuário contra o exercício negligente ou abusivo de cargo, emprego ou função pública (art. 37, § $3^{\circ}$, III); e estabeleceu a responsabilidade civil objetiva para as pessoas jurídicas de direito público e as de direito privado prestadoras de serviços públicos (art. 37, § $6^{\circ}$ ).

Em face de todos estes direitos inseridos no texto constitucional, é possível falar hoje na existência de um verdadeiro "estatuto do usuário dos serviços públicos", e, neste particular, valorizar o destinatário dos serviços que é a razão da existência destes serviços públicos.

Os direitos dos usuários do serviço público também são objeto da proteção legal na Argentina, conforme relata Jorge Luis Salomoni ${ }^{116}$ : “Os consumidores e usuários de bens e serviços tem direito, na relação de consumo, a proteção da saúde, segurança e interesses econômicos, a uma formação adequada e veraz, a liberdade de eleição e a condições de tratamento equitativo e digno, ao controle dos monopólios naturais e legais, a qualidade e eficiência dos serviços públicos e a constituição de associação de consumidores e usuários".

A Lei n. 8.987/95, de modo expresso, fez refletir os direitos dos usuários no seu artigo $7^{\circ}$, a saber: I - receber serviço adequado; II - receber do poder concedente e da

${ }^{116}$ SALOMONI, Jorge Luis. Teoria general de los servicios públicos. Buenos Aires: Villela, 1999. p. 127. 
concessionária informações para a defesa de interesses individuais ou coletivos; III - obter e utilizar o serviço, com liberdade de escolha, observadas as normas do poder concedente; III - obter e utilizar o serviço, com liberdade de escolha entre vários prestadores de serviços, quando for o caso, observadas as normas do poder concedente. IV - levar ao conhecimento do Poder Público e da concessionária as irregularidades de que tenha conhecimento, referentes ao serviço prestado; V - comunicar às autoridades competentes os atos ilícitos praticados pela concessionária na prestação do serviço; VI - contribuir para a permanência das boas condições dos bens públicos através dos quais lhes são prestados os serviços.

Impõe-se, neste passo, proceder uma breve análise desses direitos.

I - Receber o serviço adequado: serviço adequado é o que satisfaz as condições de regularidade, continuidade, eficiência, segurança, atualidade, generalidade, cortesia na sua prestação e modicidade das tarifas (art. $6^{\circ}, \S 1^{\circ}$, I, da Lei n. 8.987/95).

A Constituição do Estado de São Paulo também regulamenta o assunto no artigo 122, referindo-se a qualidade, eficiência e modicidade das tarifas; também, assim a Lei Orgânica do Município de São Paulo, no artigo 89.

Por outro lado, a Lei paulista n. 7.837, de 08.05.1992, foi alterada pela Lei n. 9.056, de 27.12.1994, que dispõe sobre concessão no âmbito estadual, traz uma definição sobre serviço adequado, ao estabelecer que é adequado o serviço que "atende ao interesse público e corresponde às exigências da qualidade, continuidade, regularidade, modicidade, cortesia e segurança".

Anterior a essas leis, contudo, já o Código de Proteção e Defesa do Consumidor estabelecia o direito básico do consumidor à "adequada e eficaz prestação dos serviços públicos em geral”, assim como, em seu artigo 22, também prescreve a obrigação dos concessionários e permissionários, sob qualquer forma de empreendimento, fornecer serviços adequados, eficientes, seguros e contínuos, sempre que se trata de serviços essenciais. 
O usuário do serviço público tem, portanto, garantido em diversos diplomas legais uma proteção especial, consistente em receber um serviço adequado. Alguns dos critérios eleitos pela Lei n. 8.987/95 para designar serviços adequados foram extraídos dos princípios gerais do serviço público e outros derivam da Lei de Concessão de serviço público.

II - Receber do poder concedente e da concessionária informações para a defesa de interesses individuais ou coletivos: o direito à informação para defesa de interesses individuais ou coletivos já está previsto pelo inciso XXXIII do artigo $5^{\circ}$ da Constituição Federal e, portanto, a previsão contida na lei apenas enfatiza o direito do usuário e a obrigação do concessionário, equiparado, para esse fim, a órgão público.

III - Obter e utilizar o serviço, com liberdade de escolha entre vários prestadores de serviços, quando for o caso, observadas as normas do poder concedente (redação dada pela Lei n. 9.648/98): a redação anterior deste inciso suscitava uma interpretação de que só poderia haver concessão remunerada se houvesse alternativa do serviço, sem ônus para o usuário. Tal interpretação decorria do fato de a redação anterior da lei apenas mencionar a liberdade de escolha e não conter a frase "entre vários prestadores, quando for o caso". O problema dessa interpretação, como explicam Eurico de Andrade Azevedo e Maria Lúcia Mazzei Alencar, "era relevante principalmente no caso de concessão de rodovias, pois nesta hipótese haveria a necessidade sempre de que outra estrada, não tarifada, estivesse a disposição do usuário". ${ }^{117}$

Com a alteração da lei, não é mais possível se interpretar dessa forma.

IV - levar ao conhecimento do poder público e da concessionária as irregularidades de que tenha conhecimento, referentes ao serviço prestado; V - comunicar às autoridades competentes os atos ilícitos praticados pela concessionária na prestação do serviço: esses incisos tratam do dever de informação e de controle atribuído ao usuário. Trata-se de uma extensão do conceito de cidadania e de participação do usuário na fiscalização do exercício do poder.

117 ALENCAR, Maria Lúcia Mazzei; AZEVEDO, Eurico de Andrade. Concessão de serviços públicos: comentários às leis 8.987 e 9.074 (parte geral) com as modificações introduzidas pela lei 9.648, de 27.5.98. São Paulo: Malheiros, 1998. p. 35. 
O usuário recebeu da lei a co-responsabilidade pelos serviços. Aliás, a participação do usuário na Administração Pública é prevista no artigo 37 da Constituição Federal.

VI - contribuir para a permanência das boas condições dos bens públicos através dos quais lhes são prestados os serviços: o usuário deve contribuir para as boas condições dos bens públicos. Trata-se de uma regra de "boa intenção"118 e que, na mesma diretriz traçada, co-responsabiliza o usuário pela prestação dos serviços públicos.

As condições que caracterizam o serviço adequado, na forma estabelecida pelo inciso I do artigo $7^{\circ}$, segundo o qual adequado é o serviço que satisfaz as condições de regularidade, continuidade, eficiência, segurança, atualidade, generalidade, cortesia na sua prestação e modicidade das tarifas, merecem exame particularizado. Vejamos:

Direito à continuidade: um dos indicadores do serviço adequado é a continuidade do serviço público. O princípio da continuidade estabelece que o serviço público não pode parar, o funcionamento deve ser contínuo e ininterrupto porque atende a uma necessidade social essencial e a sua interrupção oneraria substancialmente a comunidade.

É certo que, com relação a determinados serviços, a continuidade não significa funcionamento permanente do serviço, mas a expectativa de sua disponibilidade. ${ }^{119}$

Daí não ser a continuidade dos serviços um princípio absoluto, já que é possível e viável, em certos casos, a suspensão da prestação dos serviços pelos concessionários quando os usuários não cumprem de modo adequado as obrigações aventadas, como as que dizem respeito ao pagamento pela utilização dos serviços. Nesse caso, a interrupção deverá ser precedida de advertência ao usuário, de acordo com os princípios que regem as relações de consumo. ${ }^{120}$

Observa-se, portanto, que a doutrina estabelece distinção entre os serviços de fruição obrigatória pelos particulares e aqueles que não podem ser interrompidos, já que,

\footnotetext{
118 ALENCAR, Maria Lúcia Mazzei; AZEVEDO, Eurico de Andrade, Concessão de serviços públicos: comentários às leis 8.987 e 9.074 (parte geral) com as modificações introduzidas pela lei 9.648, de 27.5.98 cit., p. 36.

${ }^{119}$ GROTTI, Dinorá Adelaide Musetti, O serviço público e a Constituição brasileira de 1988, cit., p. 262.

${ }^{120}$ Ibidem, p. 266.
} 
conforme registra Benedicto Porto Neto, “a suspensão da sua prestação não é comportada, porque representa sacrifício do interesse da própria coletividade, que deve ser preservado (princípio da indisponibilidade do interesse público). Nesses casos, o serviço não é prestado no exclusivo interesse do usuário, mas também no da sociedade (daí a obrigatoriedade de fruição dele)". 121

De acordo com o artigo 22 do Código Brasileiro de Proteção e Defesa do Consumidor, quanto aos serviços públicos os “órgãos públicos, por si ou suas empresas concessionárias, permissionárias sob qualquer outra forma de empreendimento, são obrigados a oferecer serviços adequados, suficientes, seguros e, quanto aos essenciais, contínuos".

Essa obrigação de que os serviços essenciais sejam prestados de forma contínua, contudo, não foi repetida pela Lei n. 8.987/95, o que pode ter determinado que a obrigação não persista no direito brasileiro por duas razões: a primeira razão é porque a Lei $\mathrm{n}$. 8.987/95 é posterior à Lei n. 8.078/90, o Código Brasileiro de Proteção e Defesa do Consumidor, e lei posterior revoga a lei anterior; a segunda razão é porque a Lei das Concessões é específica e regula o mesmo assunto.

Regularidade ínsita à caracterização do serviço adequado: a regularidade na prestação dos serviços implica na "prestação devida de acordo com as regras, normas, e condições preestabelecidas para esse fim, ou que lhe sejam aplicáveis". ${ }^{122}$

O concessionário do serviço público deve garantir ao usuário um serviço prestado sem alterações injustificadas das regras fixadas para a sua prestação; em outras palavras, o usuário tem direito a uma estabilidade das regras de serviço público.

Generalidade ou universalidade do serviço "adequado": o serviço universal é aquele que é disponibilizado a todos, sem distinção. O prestador de um serviço público deve garantir que os serviços sejam prestados em todos os lugares, de forma isonômica.

\footnotetext{
${ }^{121}$ PORTO NETO, Benedicto. Concessão de serviços públicos no regime da Lei n. 8987/95: conceitos e princípios. São Paulo: Malheiros, 1998. p. 86.

${ }^{122}$ GROTTI, Dinorá Adelaide Musetti, O serviço público e a Constituição brasileira de 1988, cit., p. 266.
} 
É comum que em algumas situações a prestação de serviços seja lucrativa em uma região, mas não em outra. Pela obrigação de universalização imposta ao concessionário, ele deve atender tanto as regiões em que a prestação dos serviços é lucrativa, como a região em que é deficitária.

$\mathrm{O}$ direito de o usuário receber ou usufruir a prestação de serviços é geral e universal, criando a obrigação da concessionária de prestar os serviços para todas as pessoas, indistinta e independentemente de sua localização. Esse direito decorre do princípio da igualdade.

Trata-se de uma previsão de grande importância no contexto das concessões dos serviços públicos, porque através desse direito é possível forçar as concessionárias a prestar os serviços em áreas não tão lucrativas. Tanto que a Lei n. 9.074, de 07.07.1995, que estabelece normas para a outorga e prorrogação das concessões e permissões de serviço público, dispôs em seu artigo $3^{\circ}$, inciso IV, que o concessionário dos serviços deve dar "atendimento abrangente ao mercado, sem exclusão das populações de baixa renda e das áreas de baixa densidade populacional, inclusive rurais".

Modicidade das tarifas como característica de serviço adequado: entre os direitos dos usuários do serviço público no Brasil, insere-se o da modicidade das tarifas, assegurado pelo artigo $6^{\circ}$, parágrafo $1^{\circ}$ da Lei de Concessão.

Com a previsão legal que obriga o concessionário a cobrar pelos serviços que presta uma tarifa módica, fica o concessionário impedido de estabelecer cobrança desproporcional ao custo dos serviços. A cobrança de tarifa, quando desproporcional, poderá ser fulminada pelo vício da ilegalidade, com as conseqüências dele advindas.

A tarifa módica não significa necessariamente tarifa barata; a conceituação de tarifa módica não deve ser tomada em termos absolutos, mas se relaciona com a equação que necessariamente deve ser feita entre seu custo e seu benefício. Não se exige do concessionário a cobrança de uma tarifa que não seja suficiente para cobrir os seus custos operacionais, ou mesmo que não importe em lucro, mas que seja feita com base em princípios proporcionais, com o objetivo de atender da melhor forma possível ao usuário. 
Segurança: o artigo 14 do Código de Defesa do Consumidor considera defeituoso o serviço que não oferece segurança ao consumidor. Para garantir tal segurança, deve o fornecedor do serviço levar em consideração, dentre outras, certas circunstancias tidas como relevantes pelo texto legal, quais sejam: I - O modo de seu fornecimento; II - O resultado e os riscos que razoavelmente dele se esperam e; III - a época em que foi fornecido.

O mesmo critério de aferição de segurança adotado pelo Código de Defesa do Consumidor deve ser transportado para os serviços prestados pelos concessionários de serviço público, que não podem prestar serviços que ponham em risco a integridade física e emocional do usuário.

Atualidade, adaptabilidade ou mutabilidade dos serviços: constitui ainda direito do usuário ter o serviço de que se utiliza constantemente atualizado e renovado, pois se espera que o concessionário esteja sempre empregando novas tecnologias e novas formas de gestão dos serviços que presta. Tal atualização é pressuposto necessário para garantir a qualidade e a satisfação do serviço público prestado.

Eficiência: a principal dificuldade desta característica da concessão é entender como aplicá-la na prática, pois por eficiência espera-se o melhor desempenho possível do concessionário na atuação dos serviços públicos, sempre com vistas a prestar ao usuário serviços da melhor qualidade possível.

A eficiência como princípio de administração é obrigatória para toda a Administração Pública, uma vez que está prevista entre os princípios gerais do artigo 37 da Constituição Federal.

Nas palavras de Dinora Musseti Grotti:

“A eficiência é um 'conceito econômico', que introduz, no mundo
jurídico, parâmetros relativos de aproveitamento ótimo de recursos
escassos disponíveis para realização máxima de resultados desejados.
Não se cuida apenas de exigir que o Estado alcance resultados com os
meios que lhe são colocados à disposição pela sociedade (eficácia), mas
que os efetue o melhor possível (eficiência), tendo, assim, uma dimensão
qualitativa". ${ }^{123}$

${ }^{123}$ GROTTI, Dinorá Adelaide Musetti, O serviço público e a Constituição brasileira de 1988, cit., p. 298. 
Cortesia: o usuário tem o direito de receber um tratamento cortês, civilizado e urbano do prestador dos serviços públicos.

O direito de cortesia faz parte do rol dos direitos do usuário que foram positivados pela lei, e, portanto, deve ser respeitado pelo prestador do serviço público não apenas como norma ética, mas como norma de direito positivo, cujo descumprimento poderá gerar ao concessionário a aplicação de penalidades por parte da Administração Pública.

\subsection{Conceituação de concessão de serviço público}

Vistas as características da concessão de serviços públicos cabe, agora, fixar sua conceituação.

A concessão é uma forma de delegação da execução de serviços públicos por terceiros, realizada através de um contrato intuiti personae, com prazo certo, precário, oneroso, em que se pactuaram uma cláusula de equilíbrio econômico-financeiro e uma remuneração mediante tarifa, ou mediante tarifa e pagamento pelo Poder Público, para que o concessionário explore por sua conta e risco.

A relação que se estabelece entre concessionário e concedente é pessoal. Como leciona Carmem Lúcia Antunes Rocha:

\footnotetext{
"A concessão é prestada por particulares ou por entidade com natureza de direito privado constituída por entidade de direito público. Em qualquer caso, porém, a concessão é entregue a uma pessoa determinada segundo os termos constitucionais e legais definidos. Quer-se com isso dizer que a concessão não pode ser conferida a quem o deseje o administrador público, mas a quem o processo administrativo desenvolvido nos termos da lei, o determine. Na verdade, a concessão sequer é entregue, antes, ela é obtida; sua contratação é alcançada pelo interessado quando atendidos os termos legalmente estatuídos." 124
}

\footnotetext{
${ }^{124}$ ROCHA, Carmen Lúcia Antunes, Estudo sobre concessão e permissão de serviço público no direito brasileiro, cit., p. 45.
} 
A relação de concessão, por sua vez, deve ser estabelecida com prazo determinado. Não é possível haver uma concessão por prazo incerto, indefinido. A concessão sem prazo se assemelharia à permissão de serviços públicos.

É também precária porque a Administração Pública pode rescindi-la a qualquer momento, e onerosa porque envolve a remuneração do concessionário.

Embora seja desaconselhável que a lei traga definições (omnia definitio periculosa est), a Lei n. 8.987/95 contém os conceitos de concessão de serviços públicos e de concessão de serviço público precedido por obra pública.

De acordo com o artigo $2^{\circ}$ dessa Lei, a concessão de serviço público é definida como sendo a "delegação de sua prestação, feita pelo poder concedente, mediante licitação, na modalidade de concorrência, à pessoa jurídica ou consórcio de empresas que demonstre capacidade para seu desempenho, por sua conta e risco e por prazo determinado".

A doutrina costuma enfatizar que o conceito legal, contudo, não contém todos os elementos presentes na concessão. O dispositivo da lei não faz menção à necessidade de contrato $^{125}$, à exigência de cláusula de equilíbrio financeira, à natureza contratual da concessão e à remuneração por meio de tarifas, elementos que, contudo, estão contidos em outros artigos da Lei.

A lei também conceitua a concessão de serviço público precedida de obra pública:

\footnotetext{
“Artigo $2^{\circ}$ - Para os fins do disposto nesta Lei, considera-se:

(...)

III - concessão de serviço público precedida da execução de obra pública: a construção, total ou parcial, conservação, reforma, ampliação ou melhoramento de quaisquer obras de interesse público, delegada pelo poder concedente, mediante licitação, na modalidade de concorrência, à pessoa jurídica ou consórcio de empresas que demonstre capacidade para a sua realização, por sua conta e risco, de forma que o investimento da concessionária seja remunerado e amortizado mediante a exploração do serviço ou da obra por prazo determinado;"
}

\footnotetext{
125 DI PIETRO, Maria Sylvia Zanella, Parcerias na administração pública, cit., p. 96. Também:
} BANDEIRA DE MELLO, Celso Antonio, Curso de direito administrativo, cit., p. 691. 
A definição supra também não contempla todos os elementos que caracterizam a concessão de serviço público e, nesse sentido, a mesma crítica pode ser dirigida ao conceito legal, com a agravante de, nesse caso, o dispositivo mencionar a existência de obra pública que é objeto, mas que não pertence à concessão de serviço público, com o que "a lei fez evidente confusão entre os dois institutos". ${ }^{126}$

Enfim, partindo-se das características da concessão de serviço público analisadas e do conceito legal de concessão mencionado, pode-se dizer que ela consiste na delegação da prestação de serviços públicos para particulares, mediante contrato intuiti personae, por prazo determinado, precário, oneroso e que contenha garantias das partes envolvidas, seja do Poder Público, do concessionário e do usuário, de forma tal que o serviço seja realizado no interesse público, para atendimento de necessidades sociais essenciais que o Estado sozinho não consegue prestar.

\subsubsection{Remuneração do concessionário}

A remuneração do concessionário é feita, em princípio, por intermédio do pagamento de tarifa pelos usuários do serviço. Há, todavia, outras formas de remuneração do concessionário, conforme prevê o artigo 11 da Lei n. 8.987/95, que autoriza a "possibilidade de outras fontes provenientes de receitas alternativas, complementares, acessórias ou de projetos associados, com ou sem exclusividade, com vistas a favorecer a modicidade das tarifas”. Além dessas, há ainda a remuneração realizada direta, parcial ou integralmente pelo poder concedente, como ocorre na concessão patrocinada e na administrativa $^{127}$, baseadas na Lei n. 11.079, de 30.12.2004, a Lei das PPPs.

Na concessão tradicional, a remuneração pela tarifa é uma de suas características marcantes e que permite, em muitas ocasiões, diferenciar a concessão de um contrato de prestação de serviços, como já se viu.

A tarifa deve ser módica, conforme prevê o parágrafo $1^{\circ}$ do $\operatorname{artigo} 6^{\circ}$ da Lei n. 8.987/95. A tarifa módica é a acessível aos usuários, pois se trata de um serviço de

\footnotetext{
${ }^{126}$ BANDEIRA DE MELLO, Celso Antonio, Curso de direito administrativo, cit., p. 693.

${ }^{127}$ Em tópico específico, analisa-se a concessão administrativa como concessão de serviços públicos.
} 
interesse público em que, portanto, o concessionário não tem a mesma liberdade que possui o empresário de definir o preço de seus produtos ou serviços. Se a tarifa não for módica, cabe ao concedente atuar, utilizando os poderes que dispõe, de forma reduzi-la. Tais poderes são, todavia, limitados em razão da equação econômico-financeira que deve ser respeitada.

A Lei n. 8.897/93 reforça o interesse público revelado pela manutenção da modicidade das tarifas quando permite que, além da tarifa, o concessionário disponha de outras receitas alternativas que poderia implicar na redução dos custos do concessionário e, a final, na redução do preço da tarifa.

Com a possibilidade de o concessionário receber receitas alternativas, a tarifa deve "refletir a composição custos mais lucro mais amortização de investimentos menos receitas alternativas, complementares ou acessórias ou de projetos associados". ${ }^{28}$

O artigo $9^{\circ}$ da Lei n. 8.987/95 prevê que a tarifa deve ser fixada pelo preço da proposta vencedora da licitação e preservada pelas regras de revisão prevista na lei, no edital e no contrato.

Em outros artigos, porém, a lei admite a possibilidade de reajuste e revisão das tarifas, como ocorre nos artigos 18 , VIII, $9^{\circ}$, parágrafo $2^{\circ}$, e 23, IV.

Reajuste de preços e revisão de preço são conceitos distintos. O reajuste de preços e valores tem como função reequilibrar os preços alterados pela desvalorização monetária, que rompe a estrutura econômico-financeira do contrato. O reajuste de preços diz respeito à equação econômica do contrato, e não à sua equação financeira. ${ }^{129}$

A revisão de preços tem por função restabelecer o equilíbrio econômico-financeiro do contrato. Segundo preleciona Antonio Carlos Cintra do Amaral, “acentue-se: a) enquanto a cláusula de reajuste se insere na etapa de planejamento da contratação, a

\footnotetext{
${ }^{128}$ AMARAL, Antônio Carlos Cintra do. Concessão de serviço público. 2. ed. São Paulo. Malheiros, 2002. p. 96.

${ }^{129}$ Ibidem, p. 92.
} 
revisão se coloca na etapa de execução do objeto contratual; b) a revisão de preços tanto pode dizer respeito à equação econômico, quanto à financeira". ${ }^{130}$

A revisão, portanto, refere-se a uma recolocação econômica dos preços, a fim de que o equilíbrio inicialmente atingido seja recomposto. Vários fatores, sem nenhuma relação com a administração empresarial do concessionário, podem interferir no valor das tarifas cobradas, como enumera a doutrina: "a) alteração unilateral do contrato pela administração; b) 'fato do príncipe'; ou, c) fato superveniente e imprevisível que enseje a aplicação da teoria da imprevisão."131

A alteração unilateral do contrato pela Administração Pública e a imprevisão contratual já foram abordadas neste trabalho. $\mathrm{O}$ fato do príncipe decorre de atuação estatal que não tenha relação com o contrato de concessão de serviços públicos, como, por exemplo, aumento de tributos, congelamento de preços decorrentes de planos econômicos etc. $^{132}$

Tanto o reajuste como a revisão dos valores das tarifas devem ser homologados pelo poder concedente, a teor do artigo 29, V, da Lei n. 8.987/95, segundo o qual incumbe ao poder concedente "homologar reajustes e proceder à revisão das tarifas na forma desta Lei, das normas pertinentes e do contrato". A homologação do reajuste ou revisão pode não ocorrer por vários motivos. Assim, no exemplo de Antonio Carlos Cintra do Amaral, a tarifa, se reajustada de acordo com o disposto no contrato, ficará acima do poder aquisitivo dos usuários e poderá não ser homologada. Nesse caso, terá havido uma alteração unilateral do contrato provocada por atuação da Administração, que poderá ensejar uma indenização à concessionária pela perda da receita decorrente, se houver realmente uma perda de receita de modo que fique comprometida a equação econômico-financeira. ${ }^{133}$

\footnotetext{
${ }^{130}$ AMARAL, Antônio Carlos Cintra do, Concessão de serviço público, cit., p. 92.

${ }^{131}$ Ibidem, p. 93.

${ }^{132}$ Ibidem, p. 93.

${ }^{133}$ Ibidem, p. 99.
} 


\subsubsection{Subcontratação, subconcessão, transferência da concessão e transferência do controle acionário}

Como regra geral, a execução dos serviços concedidos deve ser realizada integralmente pela concessionária (art. 25 da Lei n. 8.987/95). O concessionário, contudo, pode contratar com terceiros o "desenvolvimento de atividades inerentes, acessórias ou complementares ao serviço concedido, bem como a implementação de projetos associados", como prevê o artigo 25 , parágrafo $1^{\circ}$.

A Lei n. 8.987/95, entretanto, prevê quatro modalidades de alteração na prestação dos serviços da concessão, com a inclusão de uma nova empresa na relação contratual, que são: a subcontratação, a subconcessão, a transferência da concessão a terceiros e a transferência do controle acionário pelo concessionário.

Nesses casos, poderá haver tanto a contratação de terceiros para atuar em conjunto com a concessionária, como a transferência a eles dos serviços concedidos.

Pela subcontratação, o concessionário de serviço público "terceiriza"134 a concessão dos serviços, mantendo a relação jurídica da concessão, que não sofre alterações. Na subconcessão, uma parte da concessão é transferida a terceiro, que passa ter relação direta com o poder concedente. Nesse caso, haverá duas concessões relacionadas ao mesmo serviço público. Na transferência da concessão, há a substituição da concessionária por outra empresa, que passará a executar os serviços concedidos. Assim, enquanto na subcontratação a empresa subcontratada não mantém nenhuma relação com o poder concedente, nas demais modalidades a nova empresa que entra na relação de concessão passa a ter uma relação direta com o concedente.

Tanto no caso da subconcessão, como na transferência, é necessária a anuência do poder concedente, conforme previsão expressa dos artigos 26 e 27 da Lei n. 8.987/95. Contudo, enquanto a lei exige processo de licitação no caso de subconcessão, não o exige na transferência da concessão e na transferência do controle acionário.

${ }^{134}$ AMARAL, Antônio Carlos Cintra do, Concessão de serviço público, cit., p. 29. 
A licitação para a subconcessão poderá ser feita pelo concedente ou pelo próprio concessionário, desde que autorizado, uma vez que na concessão de serviços públicos há a outorga de prerrogativas da Administração Pública ao concessionário. ${ }^{135}$

A inexigibilidade de processo licitatório para a transferência da concessão tem suscitado a contestação da validade jurídico-constitucional do artigo 27 da Lei n. 8.987/95, por ofensa aos artigos 37, XXI, e 175 da Constituição Federal. ${ }^{136}$

De outro lado, procurando uma interpretação do artigo 27 de modo a preservar o espírito da lei, Antonio Carlos Cintra do Amaral lembra que é necessário interpretar o artigo 27 de modo a "harmonizar" a norma com a ordem constitucional. Segundo argumenta, "se a subconcessão (cessão parcial da concessão) deve ser precedida de licitação, também a transferência (cessão total da concessão) deve ser licitável, sob pena de se permitir, mediante transferência, a outorga de concessão sem prévia licitação, com burla a normas constitucionais e legais". ${ }^{137}$

O autor desenvolve uma interessante argumentação sobre a aplicação da lei pelo administrador público, que age, na maioria das vezes, de forma vinculada. Assim, o administrador público, ciente da obrigação de realizar a licitação prevista pelo artigo 175 da Constituição Federal, deve ser o intérprete da lei e, nesse sentido, realizar licitação para a transferência. Inconstitucional, assim, seria o ato administrativo que possibilitasse a transferência sem realizar licitação.

Em apoio à sua argumentação, aduz:

\begin{abstract}
"Quando o jurista afirma que uma norma legal é inconstitucional sem ter o cuidado de examinar a possibilidade de aplicação constitucional desta norma, o administrador se abstém de aplicá-la. Termina fazendo-o sem critério e, em regra, praticando uma inconstitucionalidade. Não seria absurdo dizer-se que grande parte das inconstitucionalidades cometidas se deve não a uma lei inconstitucional, mas a uma atuação administrativa inconstitucional, para a qual contribui de certa maneira o jurista, que, em muitos casos prefere 'julgar' uma lei inconstitucional ao invés de nela buscar uma solução de aplicação conforme a Constituição." 138
\end{abstract}

\footnotetext{
${ }^{135}$ DI PIETRO, Maria Sylvia Zanella, Parcerias na administração pública, cit., p. 127.

136 DI PIETRO, Maria Sylvia Zanella, op. cit., p. 128. Ver também: BANDEIRA DE MELLO, Celso Antonio, Curso de direito administrativo, cit., p. 708.

${ }_{137}$ AMARAL, Antônio Carlos Cintra do, Concessão de serviço público, cit., p. 31.

138 Ibidem, p. 32.
} 
A posição de Amaral, contudo, não é diferente das demais no sentido de que a transferência da concessão requer a realização de certame licitatório; difere apenas na forma de interpretar a lei, vez que, antes de condená-la por inconstitucionalidade, procura aproveitá-la, com base na teoria da "interpretação conforme a Constituição".

E, nesse sentido, assiste-lhe razão. A problemática que surge reside, contudo, nos aspectos práticos da questão. Como exigir que os administradores públicos observem a regra da necessidade da licitação levando em consideração essa interpretação conforme a Constituição?

O jurista, ao argüir a ofensa à Constituição pela lei está dando a sua contribuição para que o diploma legal seja alterado, ou para que o Poder Judiciário venha atuar de forma a levar em consideração os argumentos aduzidos. Os prejudicados pela não-realização do certame licitatório é que deverão procurar a interpretação dos tribunais acerca da questão.

No caso da transferência do controle acionário, não há alteração da pessoa jurídica concessionária, mas apenas dos sócios que a compõem, e também essa transferência poderá, em tese, incorrer em desrespeito ao texto constitucional, como observa Celso Antonio Bandeira de Mello. ${ }^{139}$

Assim, nas modalidades em que há transferência da titularidade da pessoa jurídica concessionária, será sempre necessário realizar a licitação.

\subsubsection{Prazo e rescisão das concessões}

A Lei n. 8.987/95 não prevê um prazo nem um limite de prazo para as concessões de serviço público. As exigências legais limitam-se a estabelecer que ele seja determinado no edital de licitação e no contrato.

139 BANDEIRA DE MELLO, Celso Antonio, Curso de direito administrativo, cit., p. 708. Em sentido contrário: DI PIETRO, Maria Sylvia Zanella, Parcerias na administração pública, cit., p. 129. 
Entretanto, isso não significa que o prazo da concessão pode ser livremente estipulado, uma vez que deve guardar correspondência com as necessidades de manutenção do equilíbrio econômico-financeiro da concessão. ${ }^{140}$

A doutrina, de uma forma geral, descarta a aplicação aos contratos de concessão do limite temporal imposto pelo artigo 57 da Lei n. 8.666/93, porque o prazo estipulado nessa lei tem por objetivo impedir que o administrador celebre contratos que ultrapassem o exercício financeiro.

A fixação de prazo de duração de uma concessão é item de grande importância na equação econômico-financeira de um contrato. Nos cálculos do empresário, o prazo é uma variável que irá determinar o valor da tarifa que vier a ser cobrada do usuário, porque irá influir tanto na sua taxa de retorno, quanto na depreciação dos ativos que vierem a fazer parte da concessão.

A estipulação de prazo de concessão deve ser estabelecida pela Administração Pública segundo critérios eleitos na hora da contratação da concessão e tendo-se sempre presente a idéia de que a concessão poderá ser encampada pela Administração Pública a qualquer momento, mediante indenização ao concessionário.

A prorrogação do prazo é possível, desde que prevista no edital e no contrato, mas deve ser motivada pelo poder concedente e é admitida apenas em casos excepcionais, não podendo ser arbitrária ${ }^{141}$. Nesse sentido é a jurisprudência do Supremo Tribunal Federal. ${ }^{142}$

É sempre necessário, ao invés de prorrogação, verificar-se se seria o caso de realização de novo certame licitatório, para evitar ferir direitos de terceiros, eventuais interessados na participação do contrato de concessão.

\footnotetext{
${ }^{140}$ AMARAL, Antônio Carlos Cintra do, Concessão de serviço público, cit., p. 86. Também: BANDEIRA DE MELlO, Celso Antonio, Curso de direito administrativo, cit., p. 710; e DI PIETRO, Maria Sylvia Zanella, Parcerias na administração pública, cit., p. 130-131.

141 AMARAL, Antônio Carlos Cintra do, op. cit., p. 86.

142 Como exemplo, decisão que entendeu pela inviabilidade de prorrogação de concessão por prazo indeterminado ou discricionariamente dilatado (HC n. 8.437/RS, rel. Min. Carlos Velloso, j. 31.08.2004. Disponível em: <www.stf.jus.br/portal/informativo359>. Acesso em: 22 jan. 2009).
} 
Em sentido contrário, Marçal Justen Filho sustenta "a inconstitucionalidade da previsão genérica e abstrata, introduzida aprioristicamente no edital, propiciando a prorrogação do prazo da concessão. Essa solução deve ser reputada inconstitucional, não sendo albergada sequer pela alusão explícita existente no artigo 175, parágrafo único, inciso I". 143

Justen Filho argumenta que a prorrogação surgirá apenas no final do período da concessão e não poderá ser prevista no edital de licitação, pois é uma "eventualidade" derivada da "infração pelo poder concedente a seus deveres" e ensina que "o dever infringido pelo poder concedente é o de promover todas as medidas destinadas a assegurar a manutenção do equilíbrio econômico-financeiro, ao longo do prazo da concessão". ${ }^{44}$

A possibilidade de prorrogação do contrato de concessão tem vários aspectos: de um lado, a favor da prorrogação do prazo, estão os argumentos de que se atende ao interesse público quando a concessionária estiver prestando um bom serviço e, portanto, a e realização de novo certame licitatório poderá significar a interrupção dos bons serviços que estavam sendo prestados. Ademais, para a Administração Pública também é conveniente a simples prorrogação do contrato, porque não será necessária a realização de nova licitação, com todas as questões relativas a esse procedimento.

De outro, todavia, a prorrogação da concessão implica a impossibilidade de que novos participantes apresentem a sua proposta, que poderá ser mais vantajosa. Ademais, sempre existirá o direito dos terceiros de prestar os serviços públicos concedidos, desde que vitoriosos no procedimento licitatório.

Contudo, não se pode dizer que a inserção da prorrogação no edital desrespeita a Constituição de 1988, porque houve efetivamente a realização de uma licitação para a escolha de um vencedor e, portanto, restou atendida a condição imposta pelo artigo 175 do Texto Constitucional.

Não obstante, a prorrogação da concessão prevista no edital de licitação deve ser motivada, para que seja possível conhecer as razões que fundamentaram a decisão do

\footnotetext{
${ }^{143}$ JUSTEN FILHO, Marçal, Teoria geral das concessões de serviço público, cit., p. 268.

${ }^{144}$ Ibidem, p. 270.
} 
administrador público. O contrato de concessão que vier a ser elaborado com o vencedor da licitação deverá conter a cláusula contendo as condições de prorrogação da licitação, que serão elaboradas de acordo com esses fundamentos do edital.

Dessa forma, se ao final do prazo de concessão as condições forem diferentes das existentes no momento da contratação, como constou do edital e do contrato, a renovação não ocorrerá e, assim, será necessária a realização de um novo certame licitatório.

\subsubsection{A licitação nas concessões de serviço público}

A licitação, diz Helly Lopes Meirelles, é "o procedimento administrativo mediante o qual a Administração Pública seleciona a proposta mais vantajosa para o contrato de seu interesse". 145

O artigo 175 da Constituição Federal é peremptório quanto à necessidade de realização de licitação para a delegação de serviços públicos. ${ }^{146}$

De acordo com o artigo 14 da Lei n. 8.897/95, a licitação para a concessão de serviços públicos deverá ser feita nos termos da legislação própria, referindo-se à Lei n. 8.666/93, atualizada pela Lei n. 8.883/94, e com observância dos princípios da legalidade, moralidade, publicidade, igualdade, do julgamento por critérios objetivos e da vinculação ao instrumento convocatório.

A observância dos citados princípios e a exigibilidade de licitação são enfatizadas pela doutrina e pela jurisprudência, como elementos relevantes da concessão de serviços públicos. ${ }^{147}$

\footnotetext{
${ }^{145}$ MEIRELLES, Hely Lopes. Licitação e contrato administrativo. 14. ed. atual. por Eurico de Andrade Azevedo e Vera Monteiro. São Paulo: Malheiros, 2006. p. 27.

${ }^{146}$ Ver, dentre outros, o RE n. 264.621/CE (Disponível em: <www.stf.jus.br/portal/jurisprudencia/listar>. Acesso em: 19 jan. 2009), no qual o Supremo Tribunal Federal enfatiza a necessidade de licitação nos casos de concessão de serviços públicos, consoante determina os artigos 175 e 37 da Constituição Federal.

147 Assim, na ADI 2716, versando sobre a conversão de linhas municipais de transporte coletivo em permissão intermunicipal, o Supremo Tribunal Federal entendeu que a lei questionada na ação direta de inconstitucionalidade desrespeitava a Constituição Federal em dois pontos: de um lado, estabelecendo pontuação entre os licitantes, o que fere o princípio da igualdade, e, de outro, porque não observava a norma imperativa do artigo 175, que estabelece que as "concessões e as permissões de serviços públicos serão sempre precedidas de licitação"(Disponível em: <www.stf.jus.br/portal/informativo490>. Acesso em: 22 jan. 2009).
} 
A licitação pública, na Lei n. 8.987/95, apresenta as seguintes características:

Licitação na modalidade "concorrência": em obediência à ordem constitucional de realização de licitação, a Lei n. $8.987 / 95$ contemplou, logo em seu artigo 2º a obrigatoriedade de realização de licitação na modalidade "concorrência", o que também está previsto nos artigos 14 a 22.

Também a Lei n. 9.074/95 previu a necessidade de licitação, inclusive na modalidade de leilão, exceto para os serviços de telecomunicação.

Critérios de julgamento: o artigo 15 da Lei n. 9.074/95, com redação dada pela Lei n. 9.648/98, regulamenta os critérios que devem nortear o julgamento da licitação. São eles: "I - o menor valor da tarifa do serviço público a ser prestado; II - a maior oferta, nos casos de pagamento ao poder concedente, pela outorga da concessão; III - a combinação, dois a dois, dos critérios referidos nos incisos I, II e VII; IV - melhor proposta técnica, com preço fixado no edital; V - melhor proposta em razão da combinação dos critérios de menor valor da tarifa do serviço público a ser prestado com o de melhor técnica; VI melhor proposta em razão da combinação dos critérios de maior oferta pela outorga da concessão com o de melhor técnica; ou VII - melhor oferta de pagamento pela outorga após qualificação de propostas técnicas."

Critica-se o critério da maior oferta, nos casos de pagamento da outorga de concessão ao concedente, porque, em se tratando de serviço público, o Poder Público não deve estar preocupado em obter ganhos e "atribuir peso importante à maior oferta de candidato à prestação de serviço público é contribuir para que este ofereça tarifa maior, embutindo nela o custo que terá de arcar com a sua oferta, o que é antítese do desejável". ${ }^{148}$

Publicação prévia do ato licitatório: antes do edital de licitação, deve o concedente publicar o ato justificativo da intenção de delegar o serviço à iniciativa privada, conforme estabelece o artigo $5^{\circ}$.

${ }^{148}$ BANDEIRA DE MELLO, Celso Antonio, Curso de direito administrativo, 24. ed., 2007, cit., p. 702. 
Alteração das fases da licitação: a alteração das fases da licitação, introduzida pela Lei n. 11.196/2005, permite a inversão da ordem das fases de habilitação e julgamento, quando somente após a classificação será examinada a habilitação do licitante que em primeiro lugar se classificou.

\section{Participação direta ou indireta dos autores ou dos responsáveis} economicamente pelos projetos: nas licitações para concessões e permissões, os autores ou responsáveis economicamente pelos projetos básico e executivo podem participar, direta ou indiretamente, da licitação ou da execução de obras ou serviços (art. 31 da Lei 9.074/95), o que não é permitido no regime geral de licitações estabelecido no artigo $9^{\circ}$ da Lei n. 8.666/93.

Participação de consórcio de empresas na licitação: no processo licitatório em que se permita a participação de empresas em consórcio, o poder concedente pode exigir que o consórcio vencedor se constitua em uma única empresa, antes da celebração do contrato, conforme consta do artigo 20 da Lei n. 8.987/95. Justifica-se essa faculdade ao Poder Público porque, caso contrário, o controle da concessionária ficaria difícil, uma vez que ela ao mesmo tempo atuaria em seus negócios privados e na concessão, como concessionário. Ademais, não há nenhuma conveniência em misturar recursos públicos com os privados. ${ }^{149}$

Ressalte-se que há inegáveis vantagens para o administrador público em, no ato de celebração final, assinar o contrato com uma só empresa, seja porque os controles são mais fáceis, seja porque o exercício da físcalização e de todos os poderes do concedente, inclusive a intervenção, também pode ser melhor realizado.

Por essa razão é que se diz que, na verdade, o administrador deve determinar a constituição de empresa e que o concessionário não tem a faculdade de escolher entre constituí-la ou não. ${ }^{150}$

\footnotetext{
${ }^{149}$ DI PIETRO, Maria Sylvia Zanella, Parcerias na administração pública, cit., p. 136.

${ }^{150}$ BLANCHET, Luis Alberto. Concessão e permissão de serviços públicos. 1995. Curitiba: Juruá, 1995. p. 99.
} 


\section{Dispensa e inexigibilidade de licitação para a concessão de serviços públicos: a}

Lei n. 8.987/95 não disciplina a dispensa ou a inexigibilidade da licitação; contudo, o silêncio da lei não implica na possibilidade de aplicação dos dispositivos contidos na Lei n. 8.666/93, uma vez que a concessão de serviços públicos, por sua natureza, exige um processo licitatório realizado de forma a atender $^{151}$ ao artigo 175 do Texto Constitucional. $^{152}$

\subsubsection{Extinção da concessão}

A concessão poderá ser extinta nas seguintes situações: (a) termo contratual; (b) encampação; (c) caducidade; (d) rescisão; (e) anulação; e (f) falência ou extinção da empresa concessionária e falecimento ou incapacidade do titular, no caso de empresa individual.

Encampação: a encampação já foi tratada como um dos poderes do concedente na relação de concessão. A encampação caracteriza-se pela retomada do serviço pelo poder concedente, durante o prazo da concessão, por motivos de interesse público; depende de lei autorizativa específica e pode ocorrer após o pagamento de indenização ou das parcelas de investimentos vinculadas a bens reversíveis, ainda não amortizados ou depreciados, que tenham sido realizados com o objetivo de garantir a continuidade e atualidade do serviço público.

Caducidade da concessão: declarar a caducidade de uma concessão significa o poder que tem o concedente de extinguir a concessão por motivo de inexecução total ou parcial do contrato, como prescreve o artigo 38 da Lei n. 8.987/95. A caducidade pode ainda ser declarada em casos de alteração do controle acionário sem a prévia comunicação ao concedente (art. 27).

\footnotetext{
${ }^{151}$ Nesse sentido: ARAGÃO, Alexandre Santos de, Direito dos serviços públicos, cit., p. 577; DI PIETRO, Maria Sylvia Zanella, Parcerias na administração pública, cit., p. 137.

152 “(...) Lesão à ordem pública, tendo em vista o contido nos artigos 21, XII, 'e' e 175 da Constituição da República. Jurisprudência do Supremo Tribunal Federal no sentido da impossibilidade de prestação de transporte interestadual de passageiros a título precário, sem a observância do processo licitatório. Lesão à ordem administrativa; afastamento da Administração do legítimo juízo discricionário de conveniência ou permissão de serviço de transporte rodoviário interestadual de passageiros (...)." (STF - AgR STA n. 732/SP. Disponível em: <www.stf.jurisprudencia/listar>. Acesso em: 19 jan. 2009).
} 
Rescisão: para que a concessionária possa rescindir o contrato de concessão em casos de descumprimento das normas contratuais pelo poder concedente, deverá ajuizar ação judicial, observando que, nesse caso, os serviços não poderão ser interrompidos, até que a decisão judicial transite em julgado.

Anulação: a anulação é o fim do contrato de concessão por vícios de legalidade. O vício de legalidade pode tanto estar presente no edital de convocação da licitação, como no contrato celebrado entre o concedente e o concessionário. Trata-se da nulidade de um ato administrativo ou de um contrato administrativo, que segue a disciplina das nulidades administrativas, inclusive quanto à possibilidade de a Administração declará-la de ofício.

Falência ou extinção da empresa concessionária e falecimento ou incapacidade do titular, no caso de empresa individual: evidentemente com a decretação da falência do concessionário do serviço, não há condições de perdurar a concessão, que estará assim extinta, como anota Celso Antonio Bandeira de Mello. ${ }^{153}$

\subsubsection{Concessão patrocinada e concessão administrativa}

A concessão patrocinada e a concessão administrativa, também conhecidas como as parcerias público-privada.

As parcerias público-privadas, instituídas pela Lei n. 11.079/2004, surgiram no contexto do movimento que levou o Estado a procurar financiamento na iniciativa privada para projetos de infra-estrutura para os quais não dispunha de recursos suficientes. De acordo com Alexandre Santos de Aragão, a conjuntura que deu ensejo ao surgimento da idéia de parcerias-público privadas no Brasil foram:

\footnotetext{
“1) gargalos de infra-estrutura impeditivos de crescimento e conseqüente melhora na situação fiscal do Estado;

2) Existência de uma série de atividades de relevância coletiva, muitas delas envolvendo as referidas infra-estruturas, não auto-sustentáveis financeiramente e sem que o Estado tenha condições de financiá-las sozinho." 154
}

\footnotetext{
${ }^{153}$ BANDEIRA DE MELLO, Celso Antonio, Curso de direito administrativo, cit., p. 731.

154 ARAGÃO, Alexandre Santos de. As parcerias público-privadas - PPPs no direito positivo brasileiro. Revista Eletrônica de Direito Administrativo Econômico, Salvador, n. 2, maio/jun./jul. 2005. Disponível em:<http://www.direitodoestado.com/revista/REDAE-2-MAIO-2005-

ALEXANDRE\%20ARAG\%C3\%83O.pdf>. Acesso em: 19 jan. 2009, p. 36.
} 
A idéia que sustenta as parcerias público-privadas é a parceria, isto é, a união de duas partes com objetivos comuns, que não seriam obtidos isoladamente sem a formação de uma nova pessoa jurídica. No Brasil, constatou-se que o Estado não detinha recursos financeiros suficientes para suportar as obras públicas de infra-estrutura e, para esses casos, a simples concessão de serviços precedida de obra pública não se mostrava interessante, em face dos altos investimentos requeridos, que demorariam muito tempo para que fossem recuperados, se a remuneração do concessionário fosse apenas a tarifa que, pelo texto da lei deve ser módica.

A fórmula das PPPs, de certa maneira, atende a essas necessidades. As PPPs estão assim no meio caminho entre o investimento estatal integral e a remuneração única do concessionário por tarifa pública.

Com relação ao tema, ensina Agustin Gordillo:

\begin{abstract}
"As chances de fixação de uma tarifa retributiva para financiar os investimentos necessários para modernizar a serviço não existem porque, em algumas atividades, tais como o transporte e o transporte ferroviário, há um limite no valor das tarifas que podem ser cobradas.

Por seu turno, por causa da crise econômica, com recessão, inflação, desemprego, subemprego etc., é evidente que muitas pessoas não têm suficiente capacidade econômica para realizar despesa. No passado, a resposta fácil é que o Estado subsidiaria o déficit movido para cumprir obrigações sociais. Contudo, face aos problemas financeiros em dar o subsídio, a exclusão de qualquer subsídio é também demasiado fácil. É quase certo de existir, eventualmente, algum ponto intermediário o em termos da concessão ou subsídio que o Estado quer e pode fazer em termos de taxas, e as realidades da nova situação econômica e financeira." ${ }^{155}$
\end{abstract}

Costuma se dizer que as parcerias público-privadas são inspiradas nas private finance inciatives - PFIs, iniciadas na Inglaterra sob governo conservador do primeiroministro John Major em 1992, sob fortes críticas de que essas iniciativas poderiam se caracterizar como uma verdadeira privatização disfarçada.

No regime das PPIs, o Poder Público assina um contrato com os interessados e se constitui uma empresa especial. A empresa é formada para o propósito específico de

\footnotetext{
155 GORDILLO, Agostín. La concesón de obras públicas y la privatización de empresas públicas por concesión. In: _. Después de la reforma del Estado. Buenos Aires: Fundacción del Derecho Administrativo, 1998. p. II-9. Disponível em: <http://www.gordillo.com/Pdf/RE/reii.pdf>, p. II-9. Acesso em: 15 jan. 2009. (nossa tradução).
} 
prover a iniciativa financeira privada. Os proprietários da empresa são geralmente empresas de construção, provedores de serviços ou bancos. Os contratos têm previsão de duração por um prazo bem longo, usualmente de 30 a 60 anos. Durante o período contratual, a empresa constituída irá prover alguns serviços que antes eram prestados pelo setor público. A empresa é remunerada pelo seu trabalho pelas tarifas pagas. O contrato também prevê metas que se não cumpridas terão influência na remuneração da contratada, e, se depois de um período a empresa não as houver atingido, o contrato poderá ser rescindido. ${ }^{156}$

De acordo com o parlamento inglês ${ }^{157}$, há três tipos de PPIs: projetos remunerados por tarifa pública, por associação entre o Poder Público e o particular em que ambos contribuem, mas o ente privado tem o controle, e uma terceira modalidad,e que é a da prestação de serviços pelo particular ao Estado, nos casos em que são necessário investimentos financeiros.

$\mathrm{Na}$ Inglaterra, as PPIs têm sido utilizadas em larga escala, iniciando com um projeto pequeno de cem mil libras esterlinas, para a construção de uma escola, e evoluindo até servir como forma de financiar um projeto de quatro billhões de libras esterlinas para construção de um túnel.

A grande inovação das PPIs é a possibilidade de que o pagamentos pelos serviços prestados pelo ente privado é feito pelo Estado.

No Brasil, a Lei n. 11.079/2004, dentro da competência geral de legislar sobre licitação, instituída pelo artigo 22, XXVII, da Constituição Federal, instituiu as parcerias público-privadas no âmbito dos poderes da União, dos Estados, do Distrito Federal e dos Municípios, e o seu parágrafo único estendeu a sua aplicação aos órgãos da Administração Pública direta, aos fundos especiais, às sociedades de economia mista e às demais entidades controladas direta ou indiretamente pela União, Estados, Municípios e Distrito Federal.

\footnotetext{
${ }^{156}$ Disponível em: <http://en.wikipedia.org/wiki/Private_Finance_Initiative\#Description_of_PFI>. Acesso em: 15 jan. 2009.

${ }^{157}$ Disponível em: <http://www.parliament.uk/commons/lib/research/rp2001/rp01-117.pdf>. Acesso em: 15 jan. 2009.
} 
Todavia, antes da entrada em vigor da lei federal, o sistema de parceria públicoprivada já havia sido instituído em alguns Estados-membros da Federação, como foi o caso dos Estados de Minas Gerais, São Paulo, Santa Catarina, Distrito Federal, Goiás, Bahia e Ceará. Na ocasião, discutiu-se sobre a competência de os Estados instituir as parcerias público-privadas, e, portanto, sobre a constitucionalidade dessas leis.

A essa indagação, a doutrina, de uma forma geral, negou a existência de infração à Lei Maior pelos Estados na instituição de lei regulando as parcerias público-privadas, sob diversos fundamentos: primeiramente, porque se trata de matéria de direito administrativo e, portanto, o tema recai sobre a competência privativa de cada ente federativo. Além disso, as leis estaduais que instituíram as PPPs têm fundamento no artigo 25 da Constituição Federal, que dá competência aos Estados-membros legislar em tudo que não lhes seja vedado pela Constituição $\left(\S 1^{\circ}\right)$ e, finalmente, porque as PPPs foram instituídas com base na competência residual dos Estados, prevista pelo parágrafo $3^{\circ}$ do artigo 24 da Constituição Federal, segundo o qual os Estados exercerão competência legislativa plena se inexistir lei federal disciplinando normas gerais. ${ }^{158}$

Consoante o artigo 71 da Lei n. 4.320/64, entende-se por fundo especial, “o produto de receitas especificadas que por lei se vinculam à realização de determinados objetivos ou serviços, facultada a adoção de normas peculiares de aplicação", artigo que não foi revogado Lei de Responsabilidade Fiscal.

Como preleciona Kioshi Harada:

"Significa reservas de certas receitas públicas para a realização de
determinados objetivos ou serviços de interesse público, sem o
detalhamento das despesas, como acontece com o orçamento anual.
Representa uma exceção ao princípio de unidade de tesouraria, previsto
no artigo 56 da mesma Lei, pois implica separação de dinheiro, cuja
aplicação fica vinculada à consecução do objetivo que deu causa à
criação do fundo."

${ }^{158}$ MUKAI, Toshio. Parcerias público-privadas. 2. ed. Rio de Janeiro: Forense, 2006. p. 1.

${ }^{159}$ HARADA, Kiyoshi. Parecer encomendado pela Comissão de Precatórios da Ordem dos Advogados do Brasil, Seção de São Paulo, a respeito do artigo $8^{\circ}$ da Lei n. 11.079/04. Disponível em: $<$ http://www.conjur.com.br/2005-jan-21/oab-sp_lei_ppps_pontos_inconstitucionais>. Acesso em: 20 jan. 2009. 
A competência dos fundos especiais também foi contestada pela doutrina ${ }^{160}$, sob o argumento de eventual inconstitucionalidade, porque os fundos especiais não têm personalidade jurídica para exercer direitos e contrair obrigações.

Ocorre, contudo, que os fundos poderiam ser enquadrados na categoria das universalidades jurídicas, como o espólio, a massa falida e o condomínio, e, mesmo tendo uma personalidade anômala, isso não seria impeditivo à assunção de direitos e obrigações.

A Lei das PPPs, como ficou conhecida, institui dois tipos de concessão: (a) a concessão patrocinada, estabelecida no artigo $2^{\circ}$ e que se refere à concessão de serviços públicos ou de obras públicas de que trata a Lei n. 8.987, de 13.02.1995, quando envolver, adicionalmente à tarifa cobrada dos usuários, contraprestação pecuniária do parceiro público ao parceiro privado; e (b) a concessão administrativa, prevista também no artigo $2^{\circ}$ e que consiste no contrato de prestação de serviços de que a Administração Pública seja a usuária direta ou indireta, ainda que envolva execução de obra ou fornecimento e instalação de bens.

Essas duas modalidades de concessão são espécies da concessão tradicional, e portanto não trouxeram grandes inovações, uma vez que, como se viu, mesmo antes dessa lei já havia a possibilidade do Poder Público conceder a execução de serviços a terceiros e, entre as condições da concessão dos serviços, ajustar uma remuneração ao concessionário do serviço público. De acordo com Toshio Mukai, a diferença entre a concessão tradicional e as modalidades de concessão da Lei n. 11.079 são as alterações na denominação das partes, que passam a ser chamadas de parceiro público e parceiro privado, com a contrapartida do Poder Público, e não existem mais concedente e concessionário. ${ }^{161}$

Aliás, como ressalta Edmir Netto de Araújo, não se trata de uma novidade, pois ainda no tempo do Império (séc. XIX), a “implantação da maior parte das ferrovias brasileiras se deu por concessões que tinham um dispositivo contratual denominado ‘cláusula ouro', que garantia ao concessionário rentabilidade anual mínima de 7\% em ouro, tendo como método de aferição vários componentes, inclusive o número de estações". ${ }^{162}$

\footnotetext{
${ }^{160}$ MUKAI, Toshio, Parcerias Público-Privadas, cit., p. 4.

${ }^{161}$ Ibidem, mesma página.

162 ARAÚJO, Edmir Netto de, Curso de direito administrativo, cit., p. 161.
} 
A semelhança das concessões patrocinadas com as concessões tradicionais é de fato muito grande, pois na concessão tradicional, no regime jurídico da Lei n. 8.987/95, é possível remunerar o concessionário por fontes outras que não apenas a tarifa (art. 11) e, tem-se entendido que esse artigo autorizaria, em tese, que uma dessas outras fontes fosse o pagamento feito pelo Poder Público.

Alexandre Santos de Aragão ${ }^{163}$ sustenta a impossibilidade de a Lei n. 8.987/95 ser interpretada de forma a permitir a conclusão de que a concessão patrocinada poderia ser instituída simplesmente com base nessa lei. Ele desenvolve os seus argumentos dizendo que durante o período de tramitação da lei, o artigo 24, que previa a instituição de uma concessão patrocinada, foi vetado, sob o fundamento de que a garantia de remuneração dada ao concessionário incentivava a ineficiência operacional e representava um risco potencial de dispêndio de subsídio pelo Poder Público. O veto a esse artigo implica na impossibilidade de que fosse instituída a concessão patrocinada, no âmbito da Lei n. $8.987 / 95$.

Todavia, é necessário dimensionar a amplitude do artigo 24, excluído da lei por veto presidencial, porque ele limitava o período de garantia da receita bruta ao primeiro terço do prazo de concessão. Ademais, não houve nenhum veto ao artigo 11 da Lei e, finalmente, como se sustentou no início, a contrapartida do Poder Público é decisão administrativa.

Com relação à análise sob o enfoque constitucional, a Lei n. 11.079/2004 está alinhada com o preceito do artigo 175 da Constituição Federal. Chegou-se a sustentar que a melhor interpretação do artigo 175 era a de que o parceiro privado deveria ser remunerado por tarifas e, portanto, qualquer outro tipo de remuneração importaria no descumprimento do comando constitucional.

Essa interpretação não prevalece. O artigo 175 não vincula a concessão à remuneração mediante tarifa. A referência à tarifa cobrada pelo concessionário é feita apenas no inciso III do parágrafo único do referido artigo, que impõe a obrigação da lei

\footnotetext{
${ }^{163}$ ARAGÃO, Alexandre Santos de, As parcerias Público-Privadas - PPPs no direito positivo brasileiro, cit., p. 36.
} 
dispor sobre a política tarifária, o que poderá, inclusive, significar que não haverá cobrança de tarifa naquele determinado caso.

Ademais, embora tenha sido tradição remunerar o concessionário por meio de tarifa, não é possível dizer que exista um conceito "universal" de concessão e é fato que em vários países se tem adotado o conceito de concessão com remuneração pelo parceiro público, integral ou parcial, sem que isso tenha de alguma maneira desvirtuado o instituto.

O exemplo é do direito francês, que contempla várias figuras próximas e semelhantes à concessão. Segunda leciona Marçal Justen Filho ${ }^{164}$, a dificuldade que o direito francês teve em identificar um conceito de concessão resultou na existência de várias figuras:

A affermage, que é um contrato utilizado nas coletividades locais, diferencia-se da concessão pelas características de que todo investimentos são realizados pelo parceiro público, que transfere ao particular a exploração do empreendimento. O particular paga à coletividade um rendimento e recebe em nome dela uma tarifa dos usuários, que consiste na sua remuneração. ${ }^{165}$

A reggie intéréssée, consiste na atribuição de um serviço público ou uma obra ao particular, com remuneração garantida pelo Estado e proporcional ao rendimento da operação; na gérance, a gestão da atividade é atribuída ao particular, mas os lucros ou prejuízos atribuídos à coletividade; a marche d'entreprise de travaux publics, assemelha-se à concessão de serviço público precedida de obra; e, finalmente, o bail emphytéotique, que é a contratação de um particular autorizado a edificar sobre imóvel de domínio público e ao final do prazo contratual. ${ }^{166}$

Como se vê, não há um modelo único de contrato de concessão e, portanto, não é possível afirmar-se que a remuneração do concessionário direta pelo parceiro público desnatura a concessão.

\footnotetext{
${ }^{164}$ JUSTEN FILHO, Marçal, Teoria geral das concessões de serviço público, cit., p. 81.

${ }^{165}$ Ibidem, p. 81.

${ }^{166}$ Ibidem, p. 81.
} 


\subsubsection{Remissão à Lei 8.987/95}

De acordo com o artigo $3^{\circ}$ da Lei n. 11.079/2004, vários dos artigos contidos na Lei n. 8.978/95 devem ser adicionalmente aplicados, tanto à concessão administrativa, quanto à concessão patrocinada.

Às concessões administrativas são aplicados, adicionalmente, o disposto nos artigos 21, 23, 25, 27 a 39 da Lei n. 8.978. Esses artigos referem-se à licitação (art. 21), às cláusulas necessárias dos contratos (art. 23), à responsabilidade da concessionária, que não poderá alegar a fiscalização como excludente de responsabilidade (art. 25), a proibição de transferência da concessão ou a do controle societário sem a prévia anuência do poder concedente, sob pena de caducidade (art. 27), à possibilidade de garantir financiamentos utilizando-se dos direitos emergentes da concessão (arts. 28 e 28-A), aos encargos do poder concedente, aos encargos da concessionária (art. 31), à intervenção (art. 32), às formas da extinção da concessão (arts. 35, 36, 37, 38 e 39). Todas essas formas foram analisadas no capítulo da concessão tradicional para o qual se faz remissão.

Com relação às regras de contratos, a Lei n. 11.079/2004, tem algumas disposições específicas, e que, nesse caso, prevalecem sobre as disposições contidas na Lei n. 8.987/95.

Como se observa, não foram expressamente remetidas às disposições relativas aos usuários e aos seus direitos, como previsto no capítulo II (Do serviço adequado), e do Capítulo III (Dos direitos e obrigações dos usuários). Todavia, essa omissão não importa em suprimir esses direitos dos usuários porque, como já se mencionou, tais direitos têm previsão constitucional e, portanto, quando a concessão administrativa se constituir como delegação de serviço público, todas as disposições lhe serão aplicadas. Ademais, o inciso II do artigo $4^{\circ}$ da Lei institui, com a natureza de diretriz a ser perseguida, na contratação da parceria público-privada, "o respeito aos interesses e direitos dos destinatários dos serviços e dos entes privados incumbidos da sua execução".

Também não há na Lei das PPPs remissão expressa à política tarifária, o que neste caso se justifica, ante a inexistência de cobrança de tarifa na concessão administrativa. Também a ausência de remissão da Lei ao Capítulo da licitação se justifica porque a 
própria Lei n. 11.079/2004 disciplinou a matéria de licitação, introduzindo mecanismos específicos para este tipo de delegação de serviço público.

Com relação às concessões patrocinadas, o parágrafo $1^{\circ}$ do artigo $3^{\circ}$ da Lei $n$. 11.079/2004 remete a aplicação subsidiária da Lei n. 8.987/95, e, como consequiência, todas as disposições contidas naquela lei, que não conflitarem com as disposições contidas na Lei das PPPs, serão aplicadas, o que, na verdade, significa dizer que, além das regras especificamente aplicadas à concessão administrativa, também serão aplicadas as relativas à política tarifária.

De acordo com o artigo 23 da Lei n. 8.978/95, o contrato de concessão deve ter obrigatoriamente algumas cláusulas.

A essas cláusulas essenciais no contrato de concessão administrativa não se aplicam as disposições previstas no item IV, relativas ao preço das tarifas e de sua revisão.

$\mathrm{O}$ artigo 25 da Lei n. 8.987, que também se aplica às PPPs, refere-se à responsabilidade do concessionário em relação ao poder concedente, aos usuários e para com terceiros. O concessionário não poderá se eximir da responsabilização, sob a alegação de que houve fiscalização do órgão competente. Através desse dispositivo, evita-se que o concessionário dos serviços suscite a sua irresponsabilidade pelos danos que vier a causar, sob a alegação de a prestação dos serviços foi fiscalizada, e procure, desse modo, transferir essa responsabilidade ao poder concedente.

A referência ao artigo 27 da Lei diz respeito à possibilidade de superveniência da caducidade da concessão administrativa em casos de transferência da concessão ou do controle societário da concessionária sem prévia anuência do poder concedente. Sobre esse aspecto, remete-se à exposição do tema no capítulo da concessão tradicional.

O artigo 28, por sua vez, trata da possibilidade de os concessionários oferecerem os direitos da concessão como garantia em contratos de financiamento, até o limite que não comprometa a operacionalização e a continuidade da prestação dos serviços. 
O artigo 28-A estabelece a possibilidade de cessão, em caráter fiduciário, de parcela de seus créditos operacionais futuros, com a condição de que o contrato seja registrado em cartório de títulos e de documentos, para ter eficácia contra terceiros, e de que haja notificação ao Poder Público.

As demais disposições referem-se aos encargos do poder concedente (arts. 29 a 30) dos encargos da concessionária (art. 31), da intervenção (art. 32) e da extinção da concessão (art. 35), assuntos já examinados.

\subsubsection{Diretrizes}

$\mathrm{O}$ artigo $4^{\circ}$ da lei das PPPs enumera as diretrizes que devem ser observadas na contratação das parcerias público-privadas. São elas:

I - Eficiência no cumprimento das missões de Estado e no emprego dos recursos da sociedade: O conceito de eficiência para a Administração Pública refere-se ao modo de atuação do agente público, no que respeita à organização e estruturação dos órgãos da Administração Pública, com o objetivo de buscar melhores resultados na prestação do serviço público ${ }^{167}$. Ao inserir a eficiência no contexto das parcerias públicoprivadas, o legislador reforçou um princípio de cumprimento obrigatório pela Administração Pública brasileira, previsto pela Constituição Federal (art. 37).

No âmbito das parcerias público-privadas, o princípio da eficiência significa a escolha de projetos que atendam à concretização da missão do Estado, isto é, que efetivamente tragam benefício para o cidadão, usuário dos serviços. A eficiência no emprego de recursos da sociedade pode ser entendida como o melhor retorno possível para cada investimento realizado.

II - Respeito aos interesses e direitos dos destinatários dos serviços e dos entes privados incumbidos da sua execução: Embora a lei não especifique expressamente quais são os interesses e os direitos dos destinatários dos serviços, e, nesse aspecto, não

${ }^{167}$ DI PIETRO, Maria Sylvia Zanella, Direito administrativo, cit., p. 98. 
tenha feito expressa remissão aos dispositivos de igual teor da Lei n. 8.987/95, ao inseri-los como diretriz da contratação da parceria público-privada, a lei se alinha com a orientação constitucional referente ao usuário do serviço público (art. 37, § $3^{\circ}$, da CF).

A referência aos entes privados pode ser entendida no contexto da relação entre a Administração Pública e o particular como tendência a evitar os erros do passado, quando os direitos dos particulares prestadores dos serviços não eram respeitados, pois a Administração Pública atrasava pagamentos, precatórios etc. A norma, estabelecida como diretriz, reforça a obrigação do Poder Público em respeitar os direitos dos prestadores de serviços.

III - indelegabilidade das funções de regulação, jurisdicional, do exercício do poder de polícia e de outras atividades exclusivas do Estado: esta diretriz não precisaria constar do texto da lei porque essas funções públicas não podem ser objeto de delegação, em virtude de constituírem funções do Estado e, tais como, referidas no capítulo inicial desta dissertação. A inserção do dispositivo, contudo, pode ser entendida como recurso de técnica legislativa, ou mesmo regra de natureza pedagógica, pois essa lei será aplicada em todo o território brasileiro, vale dizer, em Municípios sem uma assessoria jurídica e, sendo assim, a regra tem o valor de deixar clara a proibição de delegação dessas funções estatais.

IV - responsabilidade fiscal na celebração e execução das parcerias: a lei está se referindo, também como diretriz, à necessidade de se observarem os limites impostos pela Lei de Responsabilidade Fiscal (LC n. 101/2000), e impõe limites ao administrador público na realização dessas parcerias.

A necessidade de investimentos em infra-estrutura e a constatação do esgotamento da capacidade do Estado em investir levaram à elaboração da Lei das Parcerias PúblicoPrivada. Todavia, existe o risco de utilização das PPPs como forma de burlar as regras de responsabilidade fiscal porque as PPPs podem ser contratadas por longo período e, destarte, comprometer os recursos financeiros do Poder Público, atuando como um financiamento de longo prazo para a construção de obras, e não como uma parceria do Poder Público com o parceiro privado. 
Existe uma zona de indefinição entre a contratação de uma obra com o prazo de até 35 anos de pagamento e a concessão de um serviço público sob o modelo da concessão administrativa.

A solução adotada pela lei foi a de limitar os valores utilizados para a contratação sob o regime de parceria público-privada. Por essa razão, inseriu-se o artigo 22, segundo o qual a União está limitada para contratar uma parceria público-privada, "quando a soma das despesas de caráter continuado derivadas do conjunto das parcerias já contratadas não tiver excedido, no ano anterior, a $1 \%$ (um por cento) da receita corrente líquida do exercício, e as despesas anuais dos contratos vigentes, nos 10 (dez) anos subseqüentes, não excedam a $1 \%$ (um por cento) da receita corrente líquida projetada para os respectivos exercícios".

Esse mecanismo da lei limitou os gastos com as parcerias público-privadas a $1 \%$ da receita corrente líquida da União e também a $1 \%$ da receita liquida projetada.

Observa-se que semelhante problema foi encontrado na França, nos contratos de marche d'entreprise de travaux public (contratação de empreendimento de obras públicas), em que o particular constrói uma obra pública para explorá-la com a garantia de recebimento de remuneração posterior pelo financiamento realizado. $O$ problema verificou-se com o potencial comprometimento de obrigações futuras e, ao final, o foi resolvido através da impossibilidade da vinculação da despesa ao orçamento. ${ }^{168}$

Todavia, para os Estados, o Distrito Federal e para os Municípios, a Lei n. 11.079/2004 não poderia estabelecer limites, pois se estaria introduzindo uma norma de finanças públicas veiculada por lei ordinária, o que é defeso pelo artigo 163 da Constituição Federal ${ }^{169}$. Por essa razão, o artigo 28 vinculou a transferência voluntária aos Estados, ao Distrito Federal e aos Municípios respeitando os mesmos limites impostos pela lei à União, isto é, a União só garantirá e realizará a transferência voluntária se as contratações das parcerias público-privadas não superar o limite de um por cento.

\footnotetext{
168 JUSTEN FILHO, Marçal, Teoria geral das concessões de serviço público, cit., p. 82.

169 ARAGÃO, Alexandre Santos de, As parcerias Público-Privadas - PPPs no direito positivo brasileiro, cit., p. 23.
} 
V - Transparência dos procedimentos e das decisões: prevista no inciso V do artigo $4^{\circ}$, nada mais é que a aplicação do princípio constitucional da publicidade.

Os procedimentos licitatórios, que neste caso utilizam a modalidade da tomada de preço e leilão, devem ter seus atos publicados, para que se façam válidos.

VI - Repartição objetiva de riscos entre as partes: além de uma diretriz, a repartição dos riscos entre o parceiro público e o parceiro privado também está prevista no inciso III do artigo $5^{\circ}$ da Lei n. 11.079/2004, e é uma das cláusulas que obrigatoriamente deverão constar do contrato.

Ao repartir os riscos entre o parceiro público e o parceiro privado, a Lei n. 11.079/2004 se diferencia da concessão prevista na Lei n. 8.987/95, em que o risco do negócio é imputado ao parceiro privado, temperado pela cláusula do equilíbrio econômicofinanceiro, que permite ao concessionário reequilibrar o contrato, e dos contratos administrativos, regrados pela Lei n. 8.666/93, em que os riscos são integralmente assumidos pela Administração Pública.

A divisão dos riscos aplicável aos contratos de PPPs se situa entre os dois modelos de riscos e contempla uma fórmula diferente de aplicação da cláusula do equilíbrio econômico-financeiro do contrato, como preleciona Alexandre Santos de Aragão:

\begin{abstract}
"Admite, portanto, uma manutenção da equação econômico-financeira diferente da tradicionalmente aplicável aos contratos administrativos em geral, dita estática e referenciada apenas ao momento inicial do contrato. Em uma manutenção da equação econômico-financeira dinâmica e permanentemente atualizada poderão ser incluídos elementos como previsão de demanda e de variação de custos ordinários, como insumos e pessoal, que não poderiam ser considerados como fatos imprevisíveis para efeito de re-equilíbrio de uma equação econômico-financeira estática." 170
\end{abstract}

A lei não especifica a forma pela qual os riscos serão divididos e, por essa razão, tem-se admitido adotar os mais diferenciados modelos de repartição de riscos, desde que sejam divididos. Assim, a lei não admite, em princípio, que apenas um dos parceiros

\footnotetext{
${ }^{170}$ ARAGÃO, Alexandre Santos de, As parcerias Público-Privadas - PPPs no direito positivo brasileiro, cit., p. 36.
} 
assuma integralmente a responsabilidade pelos riscos, pois a dicção legal manda que tal responsabilidade seja dividida.

O inciso II do artigo $5^{\circ}$ da Lei n. 11.079/2004 permite que os parceiros público e privado disciplinem no contrato a repartição dos riscos, inclusive os referentes ao caso fortuito, força maior, fato do príncipe e álea econômica extraordinária. Isso significa que esses riscos podem ser divididos igual ou desproporcionalmente, mas haverá sempre uma equação lógica que permita que essa desigualdade corresponda, entre outras, à diretriz de "eficiência no cumprimento das missões de Estado e no emprego de recursos da sociedade".

VII - Sustentabilidade financeira e vantagens socioeconômicas dos projetos de parceria: o projeto de parceria público-privada deverá estar baseado em uma equação de sustentabilidade financeira e de vantagens para o Estado e para o parceiro privado. Demais disso, a parceria deve efetivamente trazer vantagens socioeconômicas que justifiquem o modelo de concessão adotado.

A opção pelo modelo das PPPs significa o comprometimento de recursos público para o projeto e, por essa razão, a contratação das PPPs deve ser instituída de forma a oferecer efetivamente uma vantagem que não seria obtida em caso de uma contratação através da concessão tradicional.

O exemplo do Metrô no Estado de São Paulo ilustra essa situação, pois são grandes os benefícios sociais com a construção de novas linhas de metrô e, de outro, o Estado poderá utilizar os seus recursos em outras atividades sociais, como educação e saúde.

\subsubsection{Características}

Remuneração do concessionário: na concessão patrocinada adicionalmente à tarifa cobrada dos usuários, o concessionário também é remunerado mediante a contraprestação pecuniária do parceiro público, e na concessão administrativa a remuneração do parceiro privado é feita integralmente pelo parceiro público. Essas formas 
de remuneração distinguem a concessão patrocinada da concessão tradicional, pois nesta a remuneração do concessionário é realizada por tarifa pública.

No entanto, admite-se que essa distinção entre as duas formas de concessão pode desaparecer se, na concessão tradicional, à tarifa cobrada forem acrescidas outras fontes provenientes de receitas alternativas, complementares, acessórias ou de projetos associados, conforme prevê o artigo 11 da Lei n. 8.987/95. Tem-se entendido que as fontes alternativas de receitas mencionadas no artigo 11 podem ser tanto de "direito público (administrativo ou tributário), quanto de direito privado". ${ }^{171}$

Valor mínimo: para que a Administração Pública possa optar pela utilização da concessão patrocinada ou da concessão administrativa, o valor do contrato não pode ser inferior a vinte milhões de reais (do art. $\left.1^{\circ}, \S 4^{\circ}, I\right)$.

Prazo mínimo e máximo: o prazo do contrato que vier a ser celebrado entre a

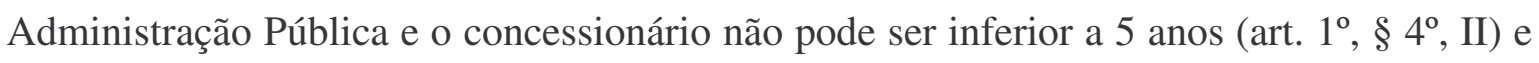
superior a 35 anos (art. $\left.5^{\circ}, \mathrm{I}\right)$.

Garantias: no regime jurídico das PPPs, o parceiro público paga diretamente ao parceiro privado a remuneração integral ou parcial, dependendo da modalidade de PPP. Para que fosse possível atrair o parceiro privado na contratação das PPPs, era preciso que houvesse garantias de pagamento, pois no Brasil era conhecida a morosidade de pagamento de compromissos assumidos pelo Poder Público.

Ora, os contratos de PPPs tendem a ser celebrados por períodos longos, uma vez que espera-se que sejam feitos grandes investimento por parte do particular, que irá se relacionar com os diferentes chefes do Poder Executivo que forem se sucedendo.

Ademais, se não houvesse garantias efetivas de que o parceiro privado iria receber os valores a que teria direito, ficaria sujeito à regra dos precatórios (art. $100 \mathrm{CF}$ ).

\footnotetext{
${ }^{171}$ ROCHA, Carmen Lúcia Antunes, Estudo sobre concessão e permissão de serviço público no direito brasileiro, cit, p. 111.
} 
Essas as razões que justificam a inserção no texto legal de garantias, que faz parte de um conjunto de regras previstas pela lei que tem o objetivo de incentivar o parceiro privado na contratação. Nesse sentido, o artigo $8^{\circ}$ da Lei n. 11.079/2004 estipula as formas que poderão garantir o parceiro privado, entre elas: I - vinculação de receitas, observado o disposto no inciso IV do artigo 167 da Constituição Federal; II - instituição ou utilização de fundos especiais previstos em lei; III - contratação de seguro-garantia com as companhias seguradoras que não sejam controladas pelo Poder Público; IV - garantia prestada por organismos internacionais ou instituições financeiras que não sejam controladas pelo Poder Público; V - garantias prestadas por fundo garantidor ou empresa estatal criada para essa finalidade; VI - outros mecanismos admitidos em lei.

Para efeitos de instituição de fundos especiais, a lei autorizou a União e suas autarquias e fundações públicas a participar de um fundo garantidor das parcerias públicoprivadas - FGP (art. 16).

A doutrina, de uma maneira geral, tem se manifestado no sentido de entender que os incisos I e II do artigo $8^{\circ}$ não respeitaram a Constituição Federal.

Com relação ao inciso I, leciona Kioshi Harada:

\begin{abstract}
"Ora, toda e qualquer receita pública, não apenas a de impostos, configura bem público indisponível, inegociável e irrenunciável porque existe como instrumento necessário ao cumprimento dos fins do Estado. Receitas públicas, estimadas na lei de meios, não se prestam ao oferecimento de garantias a permitir sua excussão pelo credor, na hipótese de inadimplemento. É pacífico na doutrina e na jurisprudência a impenhorabilidade de bens públicos. Assim sendo, as receitas públicas, como bens públicos que são, não se prestam à execução direta, consectário lógico do vínculo de natureza real, que se estabelece entre a coisa e a ação do credor pignoratício, hipotecário ou anticrético." ${ }^{172}$
\end{abstract}

Com relação ao Fundo Garantidor das Parcerias instituído no artigo 16, também se alega o potencial desrespeito do Texto Constitucional, pois haveria incompatibilidade com o artigo 165 , parágrafo $9^{\circ}$, II, que impõe a lei complementar para estabelecer condição para

\footnotetext{
${ }^{172}$ Harada, Kiyoshi. Em parecer encomendado pela Comissão de Precatórios da Ordem dos Advogados do Brasil, Seção de São Paulo, a respeito do artigo $8^{\circ}$ da Lei n. 11.079/04. Disponível em: $<$ http://www.conjur.com.br/2005-jan-21/oab-sp_lei_ppps_pontos_inconstitucionais>. Acesso em: 20 jan. 2009.
} 
instituir os fundos, ademais, também não estaria de acordo com os termos da Lei n. 4.320/64, que proíbe que os fundos garantam obrigações (art. 71). ${ }^{173}$

Alexandre Santos de Aragão, em sentido contrário, fundamenta a sua posição na interpretação do artigo 165 da Constituição Federal, que teria apenas imposto condições para que a instituição e o funcionamento de fundos sejam genericamente disciplinados por lei complementar, que já existe e é a Lei n. 4.320/64, que não veda a oferta de garantia pelos fundos.

Não obstante, a redação do artigo 165 , parágrafo $9^{\circ}$, II parece que realmente condiciona a instituição e funcionamento de fundos a lei complementar. E, sob esse angulo, quando a Lei n. 11.079/2004 institui um fundo, está em desacordo com a Lei Maior.

Há outro argumento sobre o potencial de infração à Constituição do Fundo Garantidor das Parcerias. Ele poderia significar, em tese, uma burla ao artigo 100 do Texto Constitucional, que condiciona os pagamentos devidos pela Fazenda Federal, Estadual ou Municipal, em virtude de sentença judiciária, à cobrança por precatórios.

Esse argumento, entretanto, parece não resistir ao fato de que a União pode instituir pessoas jurídicas de direito privado para desempenhar diferentes atividades, como, por exemplo, para servir de garantia a um contrato de parceria público-privada.

Sociedade de propósito específico: de acordo com o artigo $9^{\circ}$ da lei, antes da celebração do contrato de concessão, impõe-se a constituição de uma "sociedade de propósito específico" (SPE), que terá a função de implantar e gerir o objeto da parceria.

O vencedor da licitação poderá ser uma empresa e, nesse caso, constituirá uma subsidiária, que será a SPE, ou, no caso do vencedor ser um consórcio, ele mesmo poderá ser transformado em uma SPE.

\footnotetext{
${ }^{173}$ Em sentido contrário: ARAGÃO, Alexandre Santos de, As parcerias Público-Privadas - PPPs no direito positivo brasileiro, cit., p. 26.
} 
A Administração Pública poderá optar em ingressar na SPE para o fim de estabelecer a partilha de riscos, o que seria um mecanismo seguro e prático de divisão de riscos e lucros entre os parceiros público e privado, mas, nesse caso, a Administração Pública não poderá ser a controladora da SPE, por expressa proibição contida no parágrafo $4^{\circ}$ do artigo $9^{\circ}$ da Lei n. 11.079/2004. A Administração Pública poderá ter a maioria do capital, mas não do capital votante ${ }^{174}$, e, nesse caso, o Estado poderá apenas subscrever o capital sem integralizá-lo, pois a contraprestação pública só poderá ser feita após a disponibilização do serviço ou participação.

Com relação às vantagens de instituição da SPE, preleciona Alexandre Santos de Aragão que "a grande vantagem da SPE nas PPPs é facilitar o controle da execução do contrato e a saúde financeira da concessionária e do respectivo project finance, tanto por parte do poder concedente, como dos financiadores da concessionária, em virtude da segregação patrimonial, contábil e jurídica que a SPE implica". ${ }^{175}$

As PPPs, como se disse, criam uma parceria entre o Poder Público e o ente privado, e o controle do contrato será efetivamente muito facilitado em caso de haver uma sociedade de propósito especifico com contabilidade própria.

Licitação: para a escolha do parceiro público no regime da lei das parceiras público-privadas, aplicam-se as regras licitatórias do regime de licitação tradicional e algumas regras específicas desse tipo de certame licitatório.

Considerando as características da parceria público-privado, a lei estabelece as seguintes disposições para a eleição do parceiro privado:

Instituição de condições para a abertura de editais: de acordo com o artigo 10 da lei, a abertura do processo licitatório está condicionada a:

a) Elaboração preliminar de estudo técnico que demonstre a conveniência e a oportunidade da contratação, com a indicação das razões que justificam a adoção do regime de concessão da Lei de Parcerias Público-Privadas e indique que as despesas

\footnotetext{
${ }^{174}$ ARAGÃO, Alexandre Santos de, As parcerias Público-Privadas - PPPs no direito positivo brasileiro, cit., p. 36.

${ }^{175}$ Ibidem, p. 36.
} 
criadas para a Administração Pública não afetarão os resultados físcais da Lei de Responsabilidade Fiscal (LC n. 101/2000). A concessão realizada sob o regime das PPPs deve ser adotada apenas em casos excepcionais, porque existe a possibilidade de se estabelecer um prazo de até 35 anos para sua duração, o que indica que poderá haver comprometimento de receitas estatais por prazo superior ao da gestão na qual são celebrados ${ }^{176}$. Tanto é assim que a lei prevê a necessidade de elaboração de estimativa de impacto orçamentário-financeiro para os exercícios em que vigorar o contrato de parceria público-privada (inc. II). Por essa razão, a lei prevê a necessidade de que sejam justificadas as razões que levaram o administrador público a adotar o modelo das PPPs.

b) Submissão da minuta do edital e do contrato a consulta pública, o que reforça a intenção do legislador de divulgação da realização da parceria público-privada. Essa divulgação deve ser feita em jornais de grande circulação e por meio eletrônico, com a justificativa da contratação. Essa forma de divulgação é diferente da forma prevista pela Lei n. 8.666/93, nos casos em que o valor for superior a cento e cinqüenta milhões de reais, em que se prevê a realização de audiência pública. Nos dois procedimentos, haverá a possibilidade de conhecimento da intenção da Administração Pública em licitar as concorrências, dando transparência ao certame.

c) Autorização legislativa específica, nos casos em que mais de setenta por cento da remuneração do parceiro privado for paga pela Administração Pública.

Critérios próprios de julgamentos das propostas: a Lei n. 11.079/2004 prevê a adoção de critérios de julgamento específicos para o caso das concessões em que há a remuneração realizada pelo parceiro público. Poderá o administrador público levar em consideração no julgamento das propostas apresentadas o menor valor da contraprestação a ser paga pela Administração Pública ou a melhor proposta, em razão da combinação desse critério com o de melhor técnica (art. 12, II, "a" e "b").

O problema que se antevê na exigência dos critérios técnicos parece consistir na margem de discricionariedade que a matéria permite. Por essa razão, o administrador não poderá deixar de aplicar o julgamento objetivo da licitação, ou seja, “o julgamento de toda

\footnotetext{
${ }^{176}$ PORTO NETO, Benedicto. Licitação para contratação de parceria público-privada. In: SUNDFELD. Carlos Ari (Coord.). Parcerias público-privadas. São Paulo: Malheiros, 2005. p. 147.
} 
licitação que se apóie em fatores concretos pedidos pela Administração em confronto com o ofertado pelos proponentes dentro do permitido no edital". ${ }^{177}$

Possibilidade de saneamento de falhas, complementações de insuficiências ou de correções de caráter formal no curso do procedimento: desde que o licitante possa satisfazer às exigências dentro do prazo fixado no instrumento convocatório, é possível tal correção. Esta possibilidade naturalmente não alcança a alteração do conteúdo das propostas, uma vez que, nesse caso, ocorreria a possibilidade de desrespeito do direito de terceiros. Contudo, esta possibilidade, prevista no inciso IV do artigo 12 da lei, permite que competidores não sejam excluídos dos certames em razão de erros formais, como preleciona Benedicto Porto Neto:

"Ela evita a eliminação desnecessária de licitantes e propostas, com
ampliação da disputa; reduz a quantidade de recursos administrativos e
judiciais contra decisões de inabilitação ou desclassificação, agilizando o
procedimento; impede o dirigismo da licitação por meio de definições de
cláusulas editalícias obscuras ou contraditórias, para que lhes seja fixado
o sentido concreto depois da apresentação de documentos e propostas
pelos licitantes."178

Assim, a possibilidade de correção de falhas de natureza formal é mais um instrumento a permitir a escolha da melhor proposta, o que atende ao interesse público.

Propostas escritas, seguidas de lances em viva voz: prescrita no artigo 12, parágrafo $1^{\circ}$, inciso I, a possibilidade de realização de certame licitatório com apresentação de propostas escritas seguida de lances em viva voz já é prevista pela Lei 10.520/2002, que institui o pregão. Trata-se de modalidade que busca atender ao interesse público, permitindo que a melhor proposta saia vencedora do processo licitatório.

O edital poderá restringir a apresentação de lances em viva voz aos licitantes cuja proposta escrita for, no máximo, vinte por cento maior que o valor da melhor proposta, conforme estabelece o artigo 12 , parágrafo $1^{\circ}$, inciso II.

Inversão da ordem das fases de habilitação e julgamento: já tinha sido adotada pela Lei de Licitação por Pregão (Lei n. 10.520, de 17.07.2002), que altera o procedimento

\footnotetext{
${ }^{177}$ MEIRELLES, Hely Lopes, Licitação e contrato administrativo, cit., p. 40.

${ }^{178}$ PORTO NETO, Benedicto, Licitação para contratação de parceria público-privada, cit., p. 155.
} 
tradicional na licitação, permitindo que primeiro ofereçam as partes os lances e, terminada essa fase, é feita a análise dos documentos entregues pelo licitantes e que lhe permitem habilitar ao certame licitatório.

Haverá uma fase preliminar de qualificação da proposta técnica, desclassificando-se os licitantes que não alcançarem a pontuação mínima.

\section{Projeto básico}

Além dessas características, a Lei n. 11.079/2004 não exige a apresentação por parte da Administração Pública de um projeto básico. No projeto original, dispositivo acrescentado pelo Congresso Nacional determinava que o edital poderia prever a responsabilidade do contrato pela elaboração dos projetos executivos. Com esse dispositivo, o que se pretendia era limitar que o parceiro privado elaborasse o projeto executivo. Esse dispositivo foi vetado pelo chefe do Poder Executivo porque não estava de acordo com o espírito das parcerias público-privadas, que é justamente o de valer-se da experiência e expertise privados. ${ }^{179}$

De fato, a intenção da lei é justamente essa, qual seja, aproveitar a experiência do parceiro privado. Como preleciona Benedicto Porto Neto:

"Na PPP a situação pode ser diferente. Por meio dela quer-se permitir que
a iniciativa privada contribua com sua eficiência também na definição do
modelo contratual a ser adotado. À Administração está reservada a tarefa
de definir os fins a serem alcançados pela parceira; o agente privado pode
ficar encarregado de escolher os meios para que eles sejam atingidos. Há,
portanto, compartilhamento entre os parceiros na definição do contrato. A
adoção do regime da Lei $8.666 / 93$ para essa matéria acabaria afastando
esse papel do agente privado."

Por fim, há possibilidade de emprego de mecanismos privados de resolução de disputas, inclusive a arbitragem, a ser realizada no Brasil e em língua portuguesa, nos termos da Lei n. 9.307/96, para dirimir conflitos decorrentes ou relacionados ao contrato.

\footnotetext{
${ }^{179}$ ARAGÃO, Alexandre Santos de, As parcerias Público-Privadas - PPPs no direito positivo brasileiro, cit., p. 36.

${ }^{180}$ PORTO NETO, Benedicto, Licitação para contratação de parceria público-privada, cit., p. 148.
} 


\subsubsection{Concessão administrativa}

Observa-se que a concessão administrativa tem alguns aspectos peculiares.

Define-se a concessão administrativa como sendo o contrato de prestação de serviços de que a Administração é usuária mediata ou imediata, em que: (a) há investimento do concessionário na criação de infra-estrutura relevante; (b) o preço é pago periódica e diferidamente pela concedente em um prazo longo, permitindo a amortização dos investimentos e o custeio; e (c) o objeto não se restringe à execução de obra ou ao fornecimento de mão de obra e bens. ${ }^{181}$

Uma importante característica da concessão administrativa se refere à autonomia de gestão do parceiro privado. ${ }^{182}$

A autonomia da gestão do parceiro privado decorre da proibição das parcerias administrativas celebrarem contratos que tenham como objeto único o fornecimento de mão-de-obra, o fornecimento e instalação de equipamentos ou a execução de obra pública. A característica desses contratos é que são contratos de terceirização de mão-de-obra em que o prestador dos serviços não tem autonomia, pois cumpre as ordens da Administração Pública.

Sustenta-se, de outro lado, que também é característica da concessão administrativa que a remuneração do concessionário deve ter relação direta com a quantidade e ou qualidade da prestação dos serviços. Diz-se que o sistema de divisão de riscos adotado pela Lei n. 11.079/2004 não permite que a responsabilização integral do contrato seja atribuída à Administração Pública. Isso implicaria a impossibilidade de fixação de uma remuneração fixa ao concessionário.

A lei não regulamenta o assunto e, assim, não proíbe a estipulação de uma remuneração fixa. Todavia, a correspondência entre a remuneração do concessionário e a qualidade dos serviços prestados, ou a quantidade dos serviços prestados, impõe-se ao

\footnotetext{
${ }^{181}$ SUNDFELD, Carlos Ari. Projetos de Lei de Parcerias Público-Privadas. Análise e Sugestões. 2004 (mimeo).

${ }^{182}$ ARAGÃO, Alexandre Santos de, As parcerias Público-Privadas - PPPs no direito positivo brasileiro, cit., p. 36.
} 
estabelecer a remuneração do concessionário. As razões podem tanto ser encontradas nas diretrizes das PPPs, inseridas no artigo $4^{\circ}$ da lei, relativas à eficiência no cumprimento das missões do Estado, como nos direitos dos usuários da concessão, em caso de concessão de serviço público, e no espírito da Lei das Parcerias Público-Privadas.

Questionam-se alguns pontos na concessão administrativa, por exemplo, se há nela verdadeira concessão de serviço público, uma vez que a concessão administrativa diz respeito à prestação de serviços para a Administração Pública e o concessionário não é remunerado mediante tarifa, mas apenas pelo concedente dos serviços.

Nesse sentido, anota Celso Antonio Bandeira de Mello:

"É praticamente impossível conceber um serviço que possa ser mantido por meio de meras tarifas nas quais a Administração compareça como simples usuária, mas na quantidade e freqüência suficiente para acobertar tais serviços, maiormente se envolverem também a execução de obra ou implantação de bens." 183

Em sentido contrário, Floriano Peixoto de Azevedo Marques Neto sustenta que a remuneração do concessionário mediante tarifa não tipifica a concessão administrativa, que tem um regime mais amplo que a concessão típica, objeto da Lei n. 8.987/97. ${ }^{184}$

No mesmo sentido Maria Sylvia Zanella di Pietro, que embora admita que o conceito de concessão administrativa contido no parágrafo $2^{\circ}$ do $\operatorname{artigo} 2^{\circ}$ da Lei $n$. 11.079/2005 "peca pela falta de clareza"185, recorre a outros dispositivos da Lei para tentar buscar qual o significa da concessão administrativa.

Assim, à primeira vista, vê Maria Sylvia Zanella Di Pietro uma aproximação desse tipo de contrato com o contrato de serviços, sob a forma de empreitada, prevista pela Lei n. 8.666/93, mas afasta essa comparação, considerando dois pontos: em primeiro lugar, porque há menção na lei de que o parceiro privado deve sujeitar-se às Leis ns. 8.987/95

\footnotetext{
${ }^{183}$ BANDEIRA DE MELLO, Celso Antonio, Curso de direito administrativo, cit., p. 757. Em sentido contrário: DI PIETRO, Maria Sylvia Zanella, Parcerias na administração pública, cit., p. 168.

${ }^{184}$ MARQUES NETO, Floriano Peixoto de Azevedo. As parcerias público-privadas no saneamento ambiental. In: SUNDFELD. Carlos Ari (Coord.). Parcerias público-privadas. São Paulo: Malheiros, 2005. p. 289.

${ }^{185}$ DI PIETRO, Maria Sylvia Zanella, Parcerias na administração pública, cit., p. 166.
} 
(arts. 21, 23, 25 e 27 a 39) e 9.074/95, o que não acontece nos contratos de empreitada; em segundo lugar, porque a lei veda a concessão patrocinada ou administrativa que tenha por objeto único o fornecimento de mão-de-obra, fornecimento e instalação de equipamentos ou a execução de obra pública (art. $2^{\circ}, \S 4^{\circ}$, inc. III).

Em seguida, demonstra que há vários artigos da Lei n. 11.079/2004 que remetem a institutos próprios da concessão, como, por exemplo: a gestão do serviço pelo concessionário (art. 31), que inclui entre os encargos do concessionário o de prestar contas da gestão do serviço ao poder concedente e aos usuários; e o artigo 32, que prevê a intervenção e a devolução dos serviços à concessionária dos serviços; para, ao final concluir que:

\begin{abstract}
"Concessão administrativa constitui-se em um misto de empreitada (porque o serviço, mesmo que prestado a terceiros, é remunerado pela própria Administração, com se deduz do artigo $2^{\circ}$, parágrafo $3^{\circ}$ ) e de concessão de serviços públicos (porque o serviço prestado ou não a terceiros - os usuários, está sujeito a algumas normas da Lei 8.987/95, sejam relativas aos encargos e prerrogativas do poder concedente, sejam as relativas aos encargos do concessionário." 186
\end{abstract}

Também nesse sentido Alexandre dos Santos de Aragão, que fornece alguns exemplos de serviços públicos que podem ser objeto de concessão administrativa:

“(1) serviços públicos econômicos em relação aos quais o Estado decida não cobrar tarifa alguma dos usuários (rodovia, em uma região muito pobre); (2) serviços públicos sociais, como educação, a saúde, a cultura e o lazer em geral, que também podem ser prestados livremente pela iniciativa privada; (3) atividades preparatórias ou de apoio ao exercício do poder de polícia, que, sem si, é indelegável à iniciativa privada, nos termos estabelecidos no artigo $4^{\circ}$, III, da Lei 11.079/04. Seriam os casos de hotelaria em presídios, da colocação de pardais eletrônicos em vias pública, prestação de serviços de reboque para remoção de veículos estacionados irregularmente etc.; (4) atividades internas da Administração pública, em que o próprio Estado, aí incluídos os seus servidores, é único beneficiário do serviço (ex. construção e operação de uma rede de creches ou restaurantes para os servidores públicos, construção e operação de um centro de estudos sobre a gestão administrativa para elaboração de projetos para a maior eficiência do Estado)." 187

\footnotetext{
${ }^{186}$ DI PIETRO, Maria Sylvia Zanella, Parcerias na administração pública, cit., p. 168.

187 ARAGÃO, Alexandre Santos de, Direito dos serviços público, cit., p. 675. Também nesse sentido: SUNDFELD, Carlos Ary. Guia jurídico das parcerias público-privadas. In: SUNDFELD, Carlos Ary (Coord.). Parcerias público-privadas. São Paulo. Malheiros, 2005. p. 29.
} 
A crítica de Celso Antonio Bandeira de Mello acima dirige-se à tentativa de "por meios transversos, não confessados" realizar-se um simples contrato de prestação de serviços utilizando um regime muito mais vantajoso para o ente privado que contrata com o Poder Público, em que se concedem vantagens e garantias "capazes de atender os mais vetustos sonhos de qualquer contratado". ${ }^{188}$

As vantagens são as seguintes: (a) duração de um contrato até 35 anos, ao invés dos 5 anos, prorrogáveis por mais 1 ano, prazo máximo permitido pela Lei n. 8.666/93; (b) garantias aos contratados "inimagináveis" nos contratos em geral, como a vinculação de receitas - que é inconstitucional; (c) emprego de mecanismos privados de resolução de disputas, inclusive arbitragens, o que seria inadmissível nos contratos administrativos em geral e nas concessões de serviço ou obra pública; (d) pagamentos de formas diversas e variadas, tal qual previstas pelo artigo $6^{\circ}$ ("I - ordem bancária; II - cessão de créditos não tributários; III - outorga de direitos em face da Administração Pública; IV - outorga de direitos sobre bens públicos dominicais; V - outros meios admitidos em lei); (e) possibilidade de reajustes monetários automáticos, baseados em índices e formulas matemáticas; (f) previsão de penalidade ao parceiro público em caso de inadimplemento.

Essas garantias realmente constituem-se em grandes vantagens para o parceiro privado, se comparadas com as que teria em um contrato de prestação de serviços, tal qual regulado pela Lei n. 8.666/93.

Todavia, a concessão administrativa, tal como prevista na lei, pode ser aplicada em alguma situações que atendem ao interesse público, como no exemplo da construção de estradas, em que o Poder Público, por razões de política pública, não pretenda cobrar tarifas (portanto, dessa forma, não haveria como remunerar o parceiro privado por meio de tarifas). Nesse caso, os valores envolvidos são de grande monta e não haveria motivação para um ente privado construir uma obra como essa, em face dos riscos de inadimplência envolvidos, como foi marca registrada do Poder Público por muito tempo no Brasil.

De outro lado, o limite imposto pela Lei n. 11.079/2004 também restringe a utilização das parcerias público-privadas aos contratos que tenham o valor mínimo de vinte

${ }^{188}$ BANDEIRA DE MELLO, Celso Antonio, Curso de direito administrativo, cit., p. 757. 
milhões de reais, o que afasta de início a possibilidade das parcerias em substituição a contratos de prestação de serviços cotidianos.

Por essa razão, pode-se incluir entre os objetos da concessão administrativa o serviço público.

Examinadas assim, as parcerias público-privada são modalidades de prestação de serviços público inovadoras no direito administrativo brasileiro e atendem às necessidades do poder.

\subsubsection{Franquia como modalidade de concessão}

O "instituto" denominado "franquia" consiste num contrato cuja origem remonta ao direito privado, e que nasceu no direito norte-americano, através do qual o franqueador licencia a sua marca e o seu conhecimento técnico e administrativo para terceiros, interessados em desenvolver aquela determinada atividade por sua conta e risco.

O franqueado recebe do franqueador as informações necessárias para atuar, em nome próprio, a marca e o modus operandi comercial.

Assim, o contrato de franquia resulta da conjugação de dois contratos empresariais: o de licença de uso de marca e de uso do know how; assim, o contrato de franquia pode ser entendido como o contrato através do qual o franqueador transfere ao franqueado a forma de prestação de serviços e de organização da empresa.

A Lei n. 8.955/94 é o diploma legal que disciplina a adoção da franquia no Brasil. Essa lei, contudo, limita-se a conceituar a franquia e a regular a circular de oferta de franquia, que deve ser obrigatoriamente fornecida ao interessado em participar de determinado sistema de franquia. Não há nenhuma menção à franquia realizada pela Administração Pública, o que, não obstante, não vem impedindo que o instrumento seja utilizado no seu âmbito. 
A utilização de franquias para a contratação de terceiros atuarem serviços públicos no Brasil parece, à primeira vista, não se enquadrar no contexto administrativo brasileiro. Como ressalta Maria Sylvia Zanella Di Pietro:

\begin{abstract}
"Em primeiro lugar, a franquia implica a imposição de métodos de organização e trabalho do franqueador ao franqueado o que pode constituir um contra-senso, se se considera que a Administração Pública descentraliza certas atividades precisamente para fugir ao seu sistema burocrático de organização e trabalho." 189
\end{abstract}

Além disso, para a Administração Pública, de uma forma geral, o estabelecimento de franquias com particulares não tem o apelo da cessão comercial de uma "marca". Sob esse ponto de vista, apenas os serviços públicos com apelo comercial ou atividades econômicas em sentido estrito desempenhadas pelo Estado é que poderiam eventualmente concentrar características que fossem atrativas ao particular, pois a Administração Pública não detém uma "marca" distintiva.

Mas a franquia, como forma de descentralizar atividades da Administração Pública, em algumas situações, vem sendo considerada como uma das formas possíveis, uma vez que não traz prejuízo para a Administração Pública, e as obrigações impostas ao franqueado são maiores do que as previstas na própria concessão em sua forma tradicional, "uma vez que este último é obrigado a atuar segundo técnicas de organização e trabalho próprias do concedente, o que não ocorre na concessão". 190

A franquia mais conhecida e difundida no Brasil é a praticada pelos Correios. Entretanto, não há unanimidade na doutrina quanto à possibilidade de delegação dos serviços postais e do correio aéreo nacional através da franquia.

De fato, o artigo 21, X, da Constituição Federal, ao disciplinar o serviço postal e o correio aéreo nacional como uma das atribuições da União, não ressalvou a possibilidade de que tal serviço fosse explorado diretamente ou mediante autorização, concessão ou permissão, como fez nos incisos posteriores (art. 21, XI e XII); a redação desse inciso possibilita a interpretação de que estes serviços não podem ser delegados ao particular.

\footnotetext{
${ }^{189}$ DI PIETRO, Maria Sylvia Zanella, Parcerias na administração pública, cit., p. 219.

${ }^{190}$ Ibidem, p. 218.
} 
Nesse sentido entende Celso Antônio Bandeira de Mello ${ }^{191}$, que considera manifestamente inconstitucional o disposto no artigo $1^{\circ}$, inciso VII, da Lei n. 9.074, de 07.07.1995, nela inserido pela Lei n. 9.648, de 27.05.1998, que inclui os serviços postais entre as atividades passíveis de permissão ou concessão.

Marçal Justen Filho não admite a franquia para a delegação de serviços públicos a particulares. Ele considera a expressão "franquia" uma denominação incorreta e inadequada para caracterizar o vinculo jurídico existente nas franquias dos correios, porque não admite a fragmentação do serviço público. Também não admite a utilização de franquias quando a Constituição tenha vedado a possibilidade do serviço público ser delegado a particulares. ${ }^{192}$

O Tribunal de Contas da União, analisando a questão das franquias da Empresa Brasileira de Correios e Telégrafos (ECT), concluiu que se trata de "contrato de direito privado da Administração", e não de contrato administrativo. Decidiu que os contratos de franquia celebrados não consistem em concessões, ou forma especial de concessão, sob os seguintes argumentos:

“1 - O contrato de concessão deve obrigatoriamente conter cláusulas que disponham sobre intervenção, reversão e encampação. No caso em exame, essas cláusulas não se fazem presentes no contrato. É lícito presumir que se não há possibilidade de encampação, é porque não há concessão;

2 - Não parece cabível admitir concessão de serviço público em que o Poder Público não possa afastar o concessionário e assumir a prestação dos serviços utilizando-se, inclusive, dos bens pertencentes ao concessionário;

3 - Da análise do contrato celebrado verifica-se que foi cobrada taxa de publicidade. Isso descaracteriza a concessão e aproxima o pacto do direito privado.

4 - Nos contratos de concessão não há a possibilidade de o Poder Público instituir taxa, a ser paga pelo concessionário, pelo simples uso do nome. A taxa de franquia nada mais é do que um pagamento a ser feito para que se possa utilizar um nome comercial ou marca. No caso concreto o nome comercial é a marca CORREIOS.

5 - Foi exigida caução do franqueado, revelando a essência mercantil da avença;

6 - Nas concessões de serviço público, não há vinculo comercial entre o poder concedente e o concessionário;

191 BANDEIRA DE MELLO, Celso Antonio, Curso de direito administrativo, cit., p. 637.

192 JUSTEN FILHO, Marçal, Teoria geral das concessões de serviço público, cit., p. 147-148. 
7 - A previsão contratual de multa, no valor de $10 \%$, em caso de atraso no repasse das verbas devidas é outro ponto que demonstra a natureza comercial do pacto;

8 - O sistema de franquias não parece coadunar com a exigência da modicidade das tarifas que deve nortear as concessões de serviços públicos. A tarifa deixa de ser módica porque além de cobrir os custos em que incorre o concessionário para a prestação do serviço, abriga os custos referentes ao pagamento pela utilização de uma marca." ${ }^{193}$

O acórdão concluiu pela natureza privada dos contratos de franquia realizados pela ECT, concessionária de serviço público, com base no parágrafo $2^{\circ}$ do artigo 25 da Lei n. $8.987 / 95 .^{194}$

Em sentido contrário, Maria Sylvia Zanella Di Pietro, que vê na franquia uma forma de privatização diferente da forma de transferência de ações para o setor privado, prevista pela Lei n. 8.031, de 12.04.1990. Para a autora, tratar-se-ia de adoção de técnica diversa de privatização, mediante celebração de contratos que implicam não na privatização da empresa, mas na privatização da execução dos serviços públicos, por sua transferência ao setor privado, que preleciona:

"Não é demais lembrar que o surgimento de novos modelos contratuais no âmbito da Administração Pública corresponde à evolução do direito administrativo, principalmente na parte dos contratos. Enquanto no direito administrativo tradicional, mais autoritário, prevaleciam os atos unilaterais da Administração, hoje a tendência é no sentido da preferência pelos contratos." 195

Para Di Pietro, ainda, o contrato de franquia pode assumir uma modalidade de concessão de serviço público, sujeita à Lei n. 8.897, ou tomar a forma de contrato de serviço, regido pela Lei n. 8.666.

193 TCU - Processo TC n. 006.706-7, Plenário, rel. Min. Adhemar Pladini Ghisi, acórdão n. 59/1998. Disponível em: <http://contas.tcu.gov.br/portaltextual/MostraDocumento?p=1\&doc=1\&templ=default $>$. Acesso em: 13 jan. 2009.

194 “Artigo 25 - Incumbe à concessionária a execução do serviço concedido, cabendo-lhe responder por todos os prejuízos causados ao poder concedente, aos usuários ou a terceiros, sem que a fiscalização exercida pelo órgão competente exclua ou atenue essa responsabilidade. $\S 1^{\circ}$ - Sem prejuízo da responsabilidade a que se refere este artigo, a concessionária poderá contratar com terceiros o desenvolvimento de atividades inerentes, acessórias ou complementares ao serviço concedido, bem como a implementação de projetos associados. $\S 2^{\circ}$ - Os contratos celebrados entre a concessionária e os terceiros a que se refere o parágrafo anterior reger-se-ão pelo direito privado, não se estabelecendo qualquer relação jurídica entre os terceiros e o poder concedente."

${ }^{195}$ DI PIETRO, Maria Sylvia Zanella, Parcerias na administração pública, cit., p. 220. 
O contrato de franquia como modalidade de delegação de serviços públicos a particulares é uma das formas que vem sendo utilizada pela Administração Pública para descentralização dos serviços públicos. Cuida-se de forma de privatização da execução de alguns serviços públicos e está de acordo com a orientação que vem sendo adotada no direito administrativo, com base no alargamento da interpretação do conceito do instituto da concessão e de outras formas de delegação de serviços públicos.

Na verdade, o contrato de franquia não se constitui como um terceiro gênero, mas como uma espécie de contratos de concessão, pois as suas cláusulas são bastante restritivas e garantem ao franqueado a possibilidade de interferir na prestação dos serviços do franqueado, caso a sua atuação não seja da forma prevista pelo contrato. Ademais, há que se considerar que em sendo um contrato administrativo, deverá se submeter à disciplina desse tipo de contrato.

O que aqui se sustenta é que a franquia pode ser instituída pelo Poder Público como uma espécie de concessão, e, portanto, se submetendo à Lei n. 8.987/95, assim como às regras de contratos administrativos.

Com a edição da Lei n. 11.668, de 02.05.2008, a utilização da franquia pela Empresa Brasileira de Correios e Telégrafos foi regulamentada.

O texto da Lei faz remissão à Lei n. 6.538/78, que dispõe sobre os serviços postais, à aplicação subsidiária do Código Civil, à Lei das Franquias (Lei n. 8.955/94), à Lei das Licitações e Contratos Públicos (Lei n. 8.666/93), e expressamente ao inciso IV do artigo 15 da Lei n. 8.987/95, que impõe que o julgamento da licitação será realizado utilizando-se o método de melhor proposta técnica, com preço fixado no edital.

$\mathrm{O}$ artigo $4^{\circ}$ da Lei, por sua vez, também, estipula as cláusulas que obrigatoriamente deverão estar contidas no contrato de concessão, dentro das quais se destacam: prazo de vigência de dez anos, renovado por mais um ano; obrigatoriedade de estabelecimento de critérios, indicadores, fórmulas e parâmetros definidores do padrão de qualidade da atividade e da gestão; a remuneração da franqueada; os direitos dos usuários; as formas de fiscalização realizada pela Empresa Brasileira de Correios e Telégrafos; e, repetindo a 
disposição que já havia na lei das PPPs, a possibilidade de se estabelecer um foro e métodos extrajudiciais de resolução dos conflitos.

Entre os objetivos da lei, está o de proporcionar maior comodidade aos usuários, a melhoria no atendimento à população e a obrigação de que se respeitem os princípios da legalidade, impessoalidade, moralidade, publicidade e eficiência.

\subsection{Permissão}

A permissão é modalidade de delegação de serviços públicos e está prevista no artigo 175 da Constituição Federal e na Lei n. 8.987/95.

Até o advento da Constituição de 1988, a permissão era tratada como um "título precário e sem prazo certo, em caráter interino emergencial, caso em que se terá ato administrativo strictu sensu, unilateral, embora a outorga dependa da provocação e aceitação do permissionário". 196

Com a redação que foi dada ao artigo 175 e seu parágrafo único, a partir da Constituição de 1988, surgiu o problema de saber se a permissão de serviços públicos passaria a se caracterizar como um contrato, e não mais como um ato administrativo precário. A redação do artigo 175, parágrafo único, inciso I, é a seguinte:

\footnotetext{
"Parágrafo único - A lei disporá sobre:

I - o regime das empresas concessionárias e permissionárias de serviços públicos, o caráter especial de seu contrato e de sua prorrogação, bem como as condições de caducidade, fiscalização e rescisão da concessão ou permissão;"
}

Parece claro que o texto constitucional, ao se referir ao caráter especial do contrato, tanto da concessionária como da permissionária, confere evidentemente natureza contratual à permissão.

${ }^{196}$ ARAÚJO, Edmir Netto de, Curso de direito administrativo, cit., p. 164. 
Todavia, quando do início da vigência da Constituição, conforme preleciona Edmir Netto de Araújo $^{197}$, interpretou-se que a exigência de contrato dirigia-se apenas às concessões; porém, com o advento da Lei n. 8.987/95, ficou clara a intenção do legislador em conferir à permissão a natureza contratual.

A redação conferida ao artigo 40 da mencionada Lei já não mais deixava alguma dúvida:

\begin{abstract}
"Artigo 40 - A permissão de serviço público será formalizada mediante contrato de adesão, que observará os termos desta Lei, das demais normas pertinentes e do edital de licitação, inclusive quanto à precariedade e à revogabilidade unilateral do contrato pelo poder concedente.

Parágrafo único - Aplica-se às permissões o disposto nesta Lei."
\end{abstract}

Note-se que esse dispositivo legal, ao igualar a permissão às concessões, parece ter pretendido acabar com o instituto. Com efeito. Ao estabelecer que a permissão "será formalizada através de contrato de adesão", a lei a está equiparando à concessão, em que o contrato também é de adesão. E quando a lei menciona a precariedade e revogabilidade unilateral do contrato de permissão, está simplesmente reproduzindo uma característica já bem conhecida dos contratos administrativos em geral.

De outro lado, como se lê acima, a lei determinou sua aplicação à permissão de serviços públicos. Logo, impõe-se entender possível que também no caso das permissões é necessário estipular prazo contratual (art. 23). Se isso assim é, a precariedade da relação entre as partes, advinda da característica de a concessão ser um ato unilateral, precário e revogável, parece não subsistir.

Essa, todavia, não parece ser a melhor forma de compreender a figura constitucional da permissão porque se o texto constitucional diferenciou as duas modalidades de prestação de serviços públicos, impõe-se admitir que se trate de modalidades distintas de delegação. Não se pode entender a permissão sem a característica da precariedade, isto é, a possibilidade de o Poder Público revogá-la unilateralmente, a qualquer tempo, sem que seja obrigado a indenizar o permissionário.

${ }^{197}$ ARAÚJO, Edmir Netto de, Curso de direito administrativo, cit., p. 164. 
A precariedade, ensina Maria Sylvia Zanella Di Pietro, apoiada em lição de José Cretella Júnior, é uma "palavra de múltiplos sentidos, que pode significar instabilidade, transitoriedade, revogabilidade, inexistência de prazo". 198

Essa característica, entretanto, não é suficiente para diferenciar a permissão da concessão, já que também na concessão a rescisão é possível a qualquer tempo, possibilidade, aliás, que ocorre em qualquer outro tipo de contrato administrativo, com fundamento nas cláusulas exorbitantes que, por sua vez, expressam o princípio da supremacia do interesse público sobre o interesse individual, respeitados os direitos e as garantias individuais previstos no artigo $5^{\circ}$ da Constituição Federal.

Mas, para fins de distinguir a concessão da permissão, a "precariedade" tanto implica na possibilidade de revogação da permissão unilateralmente, como na impossibilidade de que se institua prazo contratual, como assevera Maria Sylvia Zanella Di Pietro:

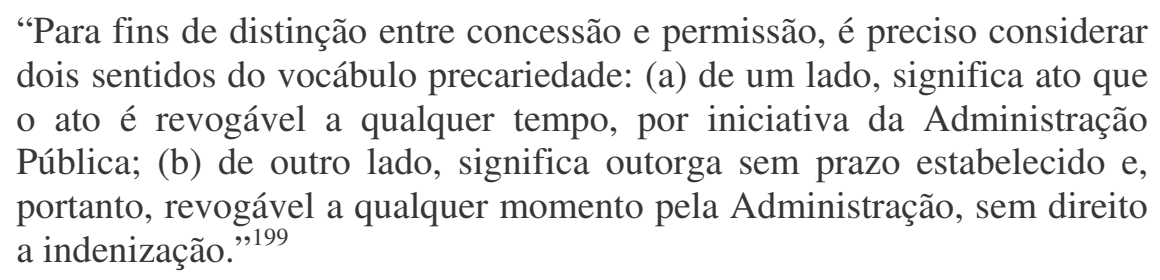

É de se notar que a eventual inserção de prazo contratual na permissão tornará essa modalidade de delegação igual à concessão, pois desaparece a diferença entre os dois institutos e, nesse caso, o permissionário passará a ter o direito de indenização pela rescisão antecipada do contrato. ${ }^{200}$

A concessão, já se viu, é um contrato ao qual deve ser atribuído um prazo de vigência $^{201}$, por expressa disposição legal. Contudo, também conforme foi amplamente exposto no item sobre a natureza jurídica da concessão, o equilíbrio do contrato de concessão, que o torna sinalagmático, decorre da incidência da cláusula de garantia do

\footnotetext{
${ }^{198}$ DI PIETRO, Maria Sylvia Zanella, Parcerias na administração pública, cit., p. 149.

${ }^{199}$ Ibidem, p. 150.

200 Nesse sentido também: DI PIETRO, Maria Sylvia Zanella, Parcerias na administração pública, cit., p. 149.

201 “Artigo 23 - São cláusulas essenciais do contrato de concessão as relativas: I - ao objeto, à área e ao prazo da concessão;"
} 
equilíbrio econômico-financeiro do contrato, o que implica, inclusive, em indenização ao concessionário, caso o contrato seja rescindido antes do prazo contratual.

Bem por isso, a conseqüência prática da precariedade da permissão é a nãoobrigação de indenização do permissionário por parte do Poder Público, em caso de revogação da permissão.

Mesmo em face dessa diferença entre permissão e concessão, é possível que o administrador público venha utilizar a permissão com prazo certo de delegação. Nesse caso, impõe-se reconhecê-la como concessão e, em conseqüência, indenizar o prestador do serviço público.

Diante do caso concreto, registra Celso Antonio Bandeira de Mello:

\footnotetext{
"Tornou-se impossível desconhecer a relevância jurídica destes fatos e o conseqüente direito do permissionário, seja a uma estabilidade do vínculo análoga à da concessão, seja - corretamente - ao direito a ser indenizado nos casos em que a extinção unilateral da permissão se efetuava sem que o permissionário houvesse incorrido em falta que a justificasse."202
}

Além da permissão, como modalidade de delegação de serviços, a Constituição Federal também menciona a autorização, prevista no artigo 21, XI. Desse tema trataremos em seguida, distinguindo a três formas de delegação de serviço público existentes no Brasil.

\subsection{Autorização}

\subsubsection{A autorização como forma de delegação de serviço público}

O artigo 175, que trata das formas de prestação de serviços públicos na Constituição Federal, conforme já visto, previu duas formas de delegação de serviço

${ }^{202}$ BANDEIRA DE MELLO, Celso Antonio, Curso de direito administrativo, cit., p. 749. 
público: a concessão e a permissão. Contudo, o artigo 21 da Constituição, em seus incisos XI e XII, disciplina a autorização também como forma de delegação de serviço público.

Ao omitir a autorização como forma de delegação de serviços no artigo 175, e incluí-la como modalidade de delegação de serviços no artigo 21, o legislador constituinte enseja um questionamento sobre a natureza da autorização e a sua aptidão para atuar como forma de delegação de serviços públicos.

Há várias teorias que tentam explicar essa "omissão". A autorização, como ensina Edmir Netto de Araújo, era apenas tratada pela doutrina, embora tivesse larga utilização em "situações precárias e emergenciais". A doutrina, diz Araújo Netto, ocupava-se em conceituar a autorização:

\begin{abstract}
"A conceituação da autorização era tradicionalmente formulada, no direito brasileiro, como ato administrativo unilateral, discricionário e não prevendo termo final, precário, pelo qual a Administração faculta ao particular o exercício de uma atividade, que, sem ela, seria proibida, removendo, portanto, o obstáculo legal impeditivo. Como exemplo, a pesquisa e lavra de jazidas minerais, porte de arma, trânsito por certos locais etc." 203
\end{abstract}

Além dessa finalidade, a autorização também era utilizada pela Administração Pública para facultar temporariamente ao particular o uso privativo de bem público.

O surgimento da autorização como instrumento de delegação de serviço público, continua Netto de Araújo, ocorreu a partir da prática de atos "caracterizados por interesses coletivos instáveis ou emergenciais, de natureza bastante transitória, sujeitos a constantes modificações e supressão a qualquer tempo, por sua índole extremamente precária” ${ }^{204}$. Atualmente, contudo, conforme admite o autor, a autorização é instrumento de delegação de serviços públicos, "com as características antes atribuídas à permissão precária", geralmente outorgada por decreto, portaria ou outro ato hábil, “desde que não contratual". ${ }^{205}$

\footnotetext{
${ }^{203}$ ARAÚJO, Edmir Netto de, Curso de direito administrativo, cit., p. 165.

${ }^{204}$ Ibidem, p. 166.

205 Ibidem, mesma página.
} 
De forma semelhante, Celso Antonio Bandeira de Mello demonstra que a autorização pode ser utilizada em duas situações: na primeira delas, para designar o exercício do poder de polícia em atividades em que há serviços de interesse privado, mas não propriamente serviços públicos; e, em outra situação, para contemplar a delegação de um serviço público com a característica de emergencialidade, ou, como diz, "se trata de resolver emergencialmente uma dada situação, até a adoção dos convenientes procedimentos por força dos quais se outorga a permissão ou concessão", ${ }^{206}$

Para Maria Sylvia Zanella di Pietro, a expressão "autorização" contida nos incisos XI e XII do artigo 21 da Constituição Federal se refere a uma delegação de serviço público, embora a autora reconheça que essa não era a sua posição inicial:

\begin{abstract}
"Até a $17^{\mathrm{a}}$ edição, vínhamos entendendo que a autorização não existe como forma de delegação de serviço prestado ao público porque o serviço é prestado no interesse exclusivo do autorizatário. A partir da $18^{a}$ edição, esse entendimento é reformulado. Os chamados serviços públicos autorizados, previstos pelo artigo 21, XI e XII da Constituição Federal são de titularidade da União, podendo ou não ser delegados ao particular, por decisão discricionária do Poder Público; e essa delegação pode ser para atendimento de necessidades coletivas, com prestação a terceiros (casos da concessão e da permissão), ou para execução no próprio benefício do autorizatário, o que não deixa de ser também de interesse público. A essa conclusão chega-se facilmente pela comparação entre os serviços de telecomunicações, energia elétrica, navegação aérea e outros referidos no artigo 21, XI e XII, com os serviços não exclusivos do Estado, como educação e saúde. Estes últimos, quando prestados pelo Estado são serviços públicos impróprios, porque abertos à iniciativa privada por força da própria Constituição; no primeiro caso, existe autorização de serviço público; no segundo, existe autorização como ato de polícia." ${ }^{207}$
\end{abstract}

Segundo ensina Maria Sylvia Zanella Di Pietro, há três acepções possíveis da expressão "autorização". A autorização pode ser ato unilateral e discricionário, pelo qual a Administração faculta ao particular o desempenho de atividade material ou a prática de ato que, sem esse consentimento, seria legalmente proibido. Outra possível utilização da expressão "autorização" no direito brasileiro é a de ato destinado a facultar o uso de bem público, a título precário; e, finalmente, um terceiro sentido atribuído ao termo é o de se entender que significa a autorização de um serviço público, a título precário, como modalidade de delegação de serviço, ao lado da concessão e da permissão.

\footnotetext{
${ }^{206}$ BANDEIRA DE MELLO, Celso Antonio, Curso de direito administrativo, cit., p. 675.

${ }^{207}$ DI PIETRO, Maria Sylvia Zanella, Direito administrativo, cit., p. 236.
} 
A autorização como forma de delegação de serviço público, por sua vez, difere da permissão e da concessão. São, assim, três formas diferentes de delegação, cada uma com a sua particularidade. O constituinte teria, assim, estabelecido uma "gradação entre a autorização, a permissão e a concessão de serviço público, segundo índice de participação ou de controle do Poder Público no concernente aos bens e serviços". ${ }^{208}$

Essa gradação entre as formas de delegação de serviço público está estabelecida da seguinte forma: tanto a permissão como a autorização são atos administrativos unilaterais, discricionários e precários, mas, no caso da permissão, há a outorga de prerrogativas públicas. Como forma de delegação de serviços públicos, essa seria a diferença entre a autorização e a permissão: a outorga de prerrogativas públicas. Da concessão, a autorização se diferenciaria, pelo fato de que a concessão é um contrato, e não um ato administrativo unilateral. ${ }^{209}$

Não obstante a Lei n. 8.987/95 não trate da autorização de serviços públicos, em vários dispositivos da Lei n. 9.074/95 há menção à expressão "autorização". Assim, no parágrafo $2^{\circ}$ do artigo $7^{\circ}$, estabelece que: "Independe de concessão, permissão ou autorização o transporte de cargas pelos meios rodoviário e aquaviário". Além desse dispositivo, em várias outras disposições, a lei remete expressamente à autorização como forma de delegação de serviços públicos. Veja-se, por exemplo, o artigo $7^{\circ}$ :

\footnotetext{
"Artigo $7^{\circ}$ - São objeto de autorização:

I - a implantação de usinas termelétricas, de potência superior a 5.000 $\mathrm{kW}$, destinada a uso exclusivo do autoprodutor;

II - o aproveitamento de potenciais hidráulicos, de potência superior a $1.000 \mathrm{~kW}$ e igual ou inferior a $10.000 \mathrm{~kW}$, destinados a uso exclusivo do autoprodutor.

Parágrafo único - As usinas termelétricas referidas neste e nos artigos $5^{\circ} \mathrm{e}$ $6^{\circ}$ não compreendem aquelas cuja fonte primária de energia é a nuclear."
}

\subsubsection{A autorização e a Lei Geral de Telecomunicações}

Apesar de toda essa discussão doutrinária, a Lei n. 9.472, de 16.06.1997, que regulamenta o inciso XI do artigo 21 e dispõe sobre a organização dos serviços de

\footnotetext{
${ }^{208}$ DI PIETRO, Maria Sylvia Zanella, Parcerias na administração pública, cit., p. 152.

${ }^{209}$ Ibidem, p. 152-153.
} 
telecomunicações, a criação e funcionamento de um órgão regulador e outros aspectos institucionais, não deu à autorização o tratamento de delegação de serviço público.

O artigo 63 da Lei n. 9.472/97 define dois tipos de regime jurídico de prestação de serviços de telecomunicação e os classifica, com relação ao seu regime jurídico, em serviços públicos e privados.

Define também o regime jurídico da delegação desses serviços e atribui o regime público aos serviços prestados mediante concessão, instituindo obrigações de universalização e de continuidade (art. 63, parágrafo único), exigência de licitação (art. 68), de contrato de concessão com cláusulas definidas, regulação sobre tarifas (art. 103), intervenção (art. 110) e extinção do contrato.

Com relação à permissão de serviços públicos, a lei prevê a sua utilização em situações que se encaixariam nas situações descritas pela doutrina como típicas de autorização de serviço público. Assim, o artigo 118 dispõe que a permissão de serviço será outorgada quando "em face de situação excepcional comprometedora do funcionamento do serviço que, em virtude de suas peculiaridades, não possa ser atendida, de forma conveniente ou em prazo adequado, mediante intervenção na empresa concessionária ou mediante outorga de nova concessão".

O parágrafo único do artigo 118 reforça esse entendimento:

\footnotetext{
"Parágrafo único - Permissão de serviço de telecomunicações é o ato administrativo pelo qual se atribui a alguém o dever de prestar serviço de telecomunicações no regime público e em caráter transitório, até que seja normalizada a situação excepcional que a tenha ensejado."
}

Também há na lei outras prescrições, como a realização de um procedimento licitatório (art. 119), a assinatura de termo de permissão com as condições prefixadas no texto legal (art. 120), a existência de um prazo (art. 122) e a extinção por revogação, caducidade e anulação. 
O tratamento dispensado pela Lei n. 9.472/97 à autorização é, na verdade, o que seria normalmente dispensado a uma licença administrativa, como se vê na disposição contida no parágrafo $1^{\circ}$ do artigo 131 :

"§ $1^{\circ}$ - Autorização de serviço de telecomunicações é o ato
administrativo vinculado que faculta a exploração, no regime privado, de
modalidade de serviço de telecomunicações, quando preenchidas as
condições objetivas e subjetivas necessárias."

A licença administrativa é ato declaratório ${ }^{210}$, através do qual a autoridade simplesmente verifica se há cumprimento dos requisitos legais e, uma vez atendidos, impõe-se a sua concessão. É, portanto, ato vinculado. Diferencia-se da autorização justamente porque é um ato vinculado. ${ }^{211}$

$\mathrm{O}$ ato vinculado realizado pelo administrador público confere ao requerente um direito subjetivo de impor à Administração Pública a realização daquele ato, o que seria impossível em se tratando de serviços públicos, porque há, por expressa disposição constitucional, uma faculdade do Poder Público em delegar ou não o serviço.

Ademais, se é ato vinculado, então não é necessário que seja realizada a licitação pública, requisito constitucional para a delegação de serviços públicos (art. 175), o que poderá suscitar a inconstitucionalidade dos artigos relativos à autorização dos serviços de telecomunicação, tal qual prevê a Lei n. 9.472/97. De fato, não há previsão de realização de licitação pública para a autorização de serviços de telecomunicações pela lei.

Ao dispensar esse tratamento à autorização, a Lei n. 9.472/97 não seguiu a orientação doutrinária sobre a interpretação do inciso XI do artigo 21 da Constituição Federal, uma vez que não lhe foi conferida a natureza jurídica de delegação de serviços públicos.

Com relação a esse aspecto, assevera Maria Sylvia Zanella Di Pietro:

\footnotetext{
${ }^{210}$ DI PIETRO, Maria Sylvia Zanella, Direito administrativo, cit., p. 238.

${ }^{211}$ Ibidem, p. 155.
} 
"É evidente que a sistemática adotada na lei, nessa parte, afronta o artigo 21, XI, da Constituição, que não permite essa distinção entre os dois tipos de serviço de telecomunicações. O que lei fez foi privatizar (não a execução do serviço, como ocorre na autorização, permissão ou concessão), mas a própria atividade ou, pelo menos, uma parte dela, o que não encontra fundamento na Constituição.",212

Parece mesmo que a lei não observou o correto tratamento à autorização, o que acaba por refletir em normas infralegais, como é o caso da Resolução Anatel n. 272, de 09. 06.2001, que trata da regulamentação do serviço de comunicação multimídia ou da regulamentação dos serviços de internet.

De acordo com o artigo 10 da Resolução n. 272, a exploração dos serviços de telecomunicações depende de autorização da Anatel e, para que seja outorgada, basta que o requerente cumpra alguns dos requisitos previstos na Resolução.

Há, dessa forma, no que respeita à normatização das telecomunicações no Brasil, um tratamento generalizado considerando a autorização como mera licença, o que poderá, em princípio, não estar de acordo com o regramento constitucional.

${ }^{212}$ DI PIETRO, Maria Sylvia Zanella, Parcerias na administração pública, cit., p. 157. 


\section{CONCLUSÕES}

Após o desenvolvimento do estudo do tema, em análise tão ampla quanto possível nos limites de uma de dissertação de mestrado, impõe-se extrair as principais conclusões a que se chegou, o que se faz a seguir:

A participação privada na prestação de serviços públicos no Brasil assume enorme relevância no quadro institucional da Administração Pública brasileira. O Estado brasileiro, como os demais Estados democráticos do mundo contemporâneo, não tem condições de dispensar a atuação dos particulares no partilhamento da prestação de serviços públicos essenciais à comunidade. A importância dessa participação foi registrada pelo constituinte, ao elevar a disciplina básica da matéria ao plano constitucional. Assim, os fundamentos da participação privada na execução dos serviços públicos se encontram na Constituição Federal, que, todavia, não esgota a disciplina da matéria sob todos os ângulos pertinentes, pelo que ela é complementada pela legislação infraconstitucional, em vários diplomas legais.

Se, de um lado, a disciplina constitucional ressalta a importância da matéria, de outro, em virtude da rigidez do texto constitucional, provoca debates sobre a viabilidade da instituição de novos serviços públicos e de novas modalidades de prestação de serviços públicos por particulares. Conclui-se, na análise desse tema, que a instituição de novos serviços públicos pela União - matéria que é disciplinada na Constituição Federal mesmo por emenda constitucional poderá encontrar óbices, em razão das limitações postas pelo artigo 60 da Constituição Federal ao poder de reforma constitucional. Já a instituição de novas formas de prestação de serviços públicos pelos particulares pode ser veiculada por emenda constitucional. Melhor, contudo, seria que essa normatividade fosse atribuída à legislação infraconstitucional, com o que a Administração Pública poderia, de modo mais ágil e mais rápido, atender às necessidades de mudanças na sua atuação, tendo em vista o interesse público.

Dentre as formas de delegação de serviço público aos particulares - concessão, permissão e autorização -, todas examinadas neste trabalho, a concessão de serviços públicos constitui a modalidade mais utilizada. Pressupõe delegação do Poder Público, e é realizada sempre mediante licitação. Rotulada de início de “concessão tradicional”, para se 
distinguir das modalidades que vão surgindo ao longo dos tempos, mereceu análise pormenorizada, vez que seus pontos principais e suas características básicas servem de parâmetro para o exame de outras formas de execução de serviços públicos.

A concessão de serviços públicos mediante delegação tem natureza contratual, consoante doutrina predominante. A relação contratual envolve a Administração Pública, o concessionário e alcança em seus efeitos os usuários - beneficiários dos serviços públicos. Analisada sob essa ótica, conclui-se que a concessão tradicional de serviços públicos, tal como disciplinada pelos textos legais pertinentes, é modalidade de prestação de serviços que atende ao interesse público de modo adequado. Resguarda os poderes da Administração Pública decorrentes do princípio da supremacia do interesse público, assegura o direito do concessionário participar de uma relação contratual equilibrada, sob o ponto de vista econômico-financeiro, e protege o usuário mediante a positivação de constitucional e legal de seus direitos. A esse respeito, a figura contemporânea da concessão segue a orientação constitucional de prestigiar a participação popular na atividade administrativa, na medida que permite aos usuários dos serviços públicos concedidos fiscalizá-los, por intermédio de vários mecanismos colocados à sua disposição.

Todavia, se a concessão tradicional de serviços públicos se mostra adequada aos seus fins, não é ela, todavia, suficiente para atender à demanda de prestação de serviços públicos na realidade contemporânea. Outras modalidades de prestação de serviços públicos passam a ser exigidas para possibilitar um atendimento ótimo dos serviços públicos. Nesse contexto, surgem a concessão patrocinada e a concessão administrativa, sob a forma das chamadas parcerias público-privadas.

Parcela da doutrina fundamenta essas novas formas de prestação de serviços públicos pelos particulares na admissão de um conceito ampliado de concessão e na interpretação extensiva do artigo 175 da Constituição Brasileira, que estabelece a regra geral das concessões no país. A legislação infraconstitucional, inicialmente editada pelos Estados e depois pela União, positiva essa modalidade nova de concessão que, não obstante, enfrenta críticas quanto à sua constitucionalidade.

A Lei das Parcerias Público-Privadas institucionaliza o conceito de parcerias entre o ente público e a empresa privada. Contém uma disciplina normativa adequada e 
significativa dessa nova modalidade de prestação privada de serviços públicos, estabelecendo regras de inegável valor, tanto no que respeita à participação da Administração Pública, como no que se relaciona com a figura do parceiro privado, e com o interesse dos usuários de serviços públicos. Regras como a imposição de limite de valor para a contratação da parceria e de tempo para sua duração, ou ainda a possibilidade das partes contratarem uma divisão de riscos específica para cada caso e a instituição de sociedade de propósito específico, asseguram a essa modalidade de prestação de serviços mecanismos úteis para a consecução do fim público almejado. Não obstante, trata-se de modalidade de prestação de serviço público por particulares ainda em fase inicial de aplicação, e que exige, necessariamente, um aperfeiçoamento ao longo de sua execução.

Outra nova modalidade de prestação privada de serviços públicos instituída por lei é a chamada franquia pública. Admitida por parte da doutrina como forma de concessão de serviço público, é, não obstante, contestada em sua constitucionalidade pelo Tribunal de Contas e mesmo pelo Superior Tribunal de Justiça. A modalidade de franquia pública mais conhecida no ordenamento brasileiro é a instituída pela Empresa Brasileira de Correios e Telégrafos e foi regulada com fundamento no artigo 21, inciso X, da Constituição Federal. Apesar das contestações, a franquia parece servir ao modelo de delegações brasileiro porque permite, em casos como o do serviço postal e correio aéreo nacional, que a prestação dos serviços atinja outras localidades, sem custos para o Estado, e, portanto, um melhor atendimento aos usuários do serviço público.

A permissão apresenta-se como forma de delegação de serviços públicos a particulares. Dotada de características tais como, ao mesmo tempo, a precariedade e a delegação de poderes ao permissionário, é de grande utilidade em determinadas situações em que não há o interesse do administrador em dar prazo certo na delegação.

A autorização é utilizada nos casos em que são delegados serviços de forma precária, sem contrato, sem delegação de poderes ao autorizatário, e, na modelagem delegatória brasileira, tem atuado de forma muito prática para atender a casos em que é necessário delegar serviços nessas situações. 


\section{REFERÊNCIAS}

AGUILLAR, Fernando Herren. Direito econômico: do direito nacional ao direito supranacional. São Paulo: Atlas, 2006.

ALENCAR, Maria Lúcia Mazzei; AZEVEDO, Eurico de Andrade. Concessão de serviços públicos: comentários às leis 8.987 e 9.074 (parte geral) com as modificações introduzidas pela lei 9.648, de 27.5.98. São Paulo: Malheiros, 1998.

ALMEIDA, Fernanda Dias Menezes de. Competências na Constituição de 1988. 2. ed. São Paulo: Atlas, 2000.

As parcerias público-privadas e sua aplicação pelo Estado Brasileiro. In: SUNDFELD, Carlos Ary (Coord.). Parcerias Público-Privadas. São Paulo: Malheiros, 2005.

AMARAL, Antônio Carlos Cintra do. Concessão de serviço público. 2. ed. rev., atual. e ampl. São Paulo. Malheiros, 2002.

ARAGÃO, Alexandre Santos de. Direito dos serviços públicos. Rio de Janeiro. Forense, 2007.

As parcerias público-privadas - PPPs no direito positivo brasileiro. Revista Eletrônica de Direito Administrativo Econômico, Salvador, n. 2, maio/jun./jul. 2005. Disponível em: <http://www.direitodoestado.com/revista/REDAE-2-MAIO-2005ALEXANDRE\%20ARAG\%C3\%83O.pdf>. Acesso em: 19 jan. 2009, p. 36.

ARAÚJO, Edmir Netto de. Administração indireta brasileira. Rio de Janeiro: Forense Universitária, 1997. . Contrato administrativo. São Paulo: Revista dos Tribunais, 1987. . Curso de direito administrativo. 3. ed. São Paulo: Saraiva, 2007. . Do negócio jurídico administrativo. São Paulo: Revista dos Tribunais, 1992. - A nova lei federal de concessões e permissões de serviços públicos e obras públicas. Revista da Procuradoria Geral do Estado de São Paulo, n. 43, p. 89-116, jun. 1995. 
BACELlAR FILHO, Romeu Felipe; BLANCHET, Luiz Alberto. Serviços públicos: estudos dirigidos. Belo Horizonte: Fórum, 2007.

BANDEIRA DE MELlO, Celso Antonio. Concessão de obra pública: peculiaridades, regime jurídico. Revista de Direito Público, São Paulo, v. 24, n. 96, p. 101-109, out./dez., 1990.

. Curso de direito administrativo. 24. ed. São Paulo: Malheiros, 2007.

. Natureza e regime jurídico das autarquias. São Paulo: Revista dos Tribunais, 1969.

. Prestação de serviços públicos e administração indireta. 2. ed. São Paulo: Revista dos Tribunais, 1987.

BARROSO, Luís Roberto. Regime constitucional do serviço postal: legitimidade de atuação da iniciativa privada. Revista de Direito da Associação dos Procuradores do Estado do Rio de Janeiro, Rio de Janeiro, Lumen Juris, v. 9, p. 127-160, 2002.

BLANCHET, Luis Alberto. Concessão e permissão de serviços públicos. 1995. Curitiba: Juruá, 1995.

BOBBIO, Norberto; MATTEUCCI; Nicola; PASQUINO, Gianfranco. Dicionário de política. Prefácio de Fernando Henrique Cardoso. Tradução de Carmen C. Varrialle et al.; coordenação da tradução de João Ferreira. 5. ed. Brasília; São Paulo: Editora da Universidade de Brasília; Imprensa Oficial do Estado de São Paulo (IMESP), 2004. 2 v.

BONAVIDES, Paulo. Ciência política. 10. ed. 13. tiragem. São Paulo: Malheiros, 2004.

BUCCI, Maria Paula Dallari. Direito administrativo e políticas públicas. São Paulo: Saraiva, 2002.

CAETANO, Marcelo. Manual de direito administrativo. 10. ed. rev. e atual. por Diogo Freitas do Amaral. Coimbra: Almedida, 1994. 
CASSAGNE, Juan Carlos. Derecho administrativo. 4. ed. ampl. y actual. Buenos Aires: Abeledo-Perrot, 1993.

CRETELlA JUNIOR, José. Comentários à Constituição de 1988: arts. 170 a 232. 2. ed. Rio de Janeiro: Forense Universitária, 1993. v. 8.

CRETElla NETO, José. Comentários à Lei das Parcerias Público-Privadas - PPPs. Rio de Janeiro: Forense, 2005.

CUELLAR, Leila. As agências reguladoras e seu poder normativo. São Paulo: Dialética, 2001.

DALLARI, Adilson de Abreu. Direito ao uso dos serviços públicos. Revista Trimestral de Direito Público, n. 13, p. 210-215, 1996.

DALLARI, Dalmo de Abreu. Elementos da teoria geral do Estado. São Paulo: Saraiva, 2003.

DI PIETRO, Maria Sylvia Zanella. Direito administrativo. 19. ed. São Paulo: Atlas, 2005. Parcerias na administração pública. 5. ed. São Paulo: Malheiros, 2005.

DROMI, Roberto. Derecho administrativo. Buenos Aires: Ediciones Ciudad Argentina, 1996.

FIGUEIREDO, Lúcia Valle. Curso de direito administrativo. 3. ed. São Paulo: Malheiros, 1998.

GONÇALVES, Carlos Roberto. Direito civil brasileiro. São Paulo: Saraiva, 2004. v. 3.

GONÇALVES, Pedro. A concessão de serviços públicos: uma aplicação da técnica concessória. Coimbra: Almedina, 1999. 
GORDILLO, Agustín. La adminitración paralela: el parasistema jurídico-administrativo. Madrid: Civitas, 1982.

La concesón de obras públicas y la privatización de empresas públicas por concesión. In: - Después de la reforma del Estado. Buenos Aires: Fundacción del Derecho Administrativo, 1998. p. II-9. Disponível em: <http://www.gordillo.com/Pdf/RE/reii.pdf>, p. II-9. Acesso em: 15 jan. 2009.

GRAU, Eros Roberto. A ordem econômica na Constituição de 1988: interpretação e crítica. 12. ed. rev. e atual. São Paulo: Malheiros, 2007.

GROTTI, Dinorá Adelaide Musseti. Contratos de gestão e outros tipos de acordos celebrados pela Administração. Disponível em: <ttp://www.tcm.sp.gov.br/legislacao/doutrina/14a18_06_04/dinora_mussetti1.htm>. Acesso em: 12 jan. 2009.

O serviço público e a Constituição Brasileira de 1988. São Paulo: Malheiros, 2003.

HARADA, Kiyoshi. Parecer encomendado pela Comissão de Precatórios da Ordem dos Advogados do Brasil, Seção de São Paulo, a respeito do artigo $8^{\circ}$ da Lei n. 11.079/04. Disponível em: <http://www.conjur.com.br/2005-jan-21/oabsp_lei_ppps_pontos_inconstitucionais>. Acesso em: 20 jan. 2009.

JUSTEN FILHO, Marçal. Curso de direito administrativo. 2. ed. São Paulo: Saraiva, 2006. . Teoria geral das concessões de serviço público. São Paulo: Dialética, 2003.

LOUREIRO, Francisco Eduardo. Código Civil comentado: doutrina e jurisprudência. In: PELUSO, Cezar. (Org.). Código Civil comentado: doutrina e jurisprudência. 2. ed. São Paulo: Manole, 2008.

MARQUES NETO, Floriano Peixoto de Azevedo. As parcerias público-privadas no saneamento ambiental. In: SUNDFELD. Carlos Ari (Coord.). Parcerias público-privadas. São Paulo: Malheiros, 2005. . Reestruturação do setor postal brasileiro. Revista Trimestral de Direito Público, v. 19, p. 149-169, 1997. 
MASAGÃO, Mário. Natureza Jurídica da concessão de serviço público. São Paulo: Saraiva, 1933.

MEDAUAR, Odete. Direito administrativo moderno. 5. ed. São Paulo: Revista dos Tribunais. 2001.

O direito administrativo em evolução. 2. ed. São Paulo: Revista dos Tribunais, 2003.

Serviço público. Boletim de Direito Administrativo, São Paulo, v. 8, n.12, p. 723731, dez. 1992.

MEIRELLES, Hely Lopes. Direito administrativo brasileiro. 27. ed. São Paulo: Malheiros, 2002.

Direito administrativo brasileiro. 20. ed. São Paulo: Malheiros, 1990.

Licitação e contrato administrativo. 14. ed. atual. por Eurico de Andrade Azevedo e Vera Monteiro. São Paulo: Malheiros, 2006.

MONTESQUIEU, Charles Louis de Secondat, Baron de La Brède et de. O espírito das leis. Tradução de Fernando Henrique Cardoso e Leôncio Martins Rodrigues. Brasília: Editora da Universidade de Brasília, 1982.

MOREIRA NETO, Diogo de Figueiredo. Curso de direito administrativo. 14. ed. Rio de Janeiro: Forense, 2006.

MUKAI, Toshio. Parcerias público-privadas. 2. ed. Rio de Janeiro: Forense, 2006.

NERY JÚNIOR, Nelson et al. Código Brasileiro de Defesa do Consumidor comentado pelos autores do Anteprojeto. 7. ed. Rio de Janeiro: Forense Universitária, 2001.

PIMENTEL, Darci Fernandes. Modalidades de parcerias entre o poder público e a iniciativa privada na execução de obras elou prestação de serviços públicos. Disponível em: <http://www.marica.com.br/2005b/2806orlandosf.htm>. Acesso em: 12 jan. 2009. 
PINTO, Bilac. O declínio das sociedades de economia mista e o advento das modernas empresas públicas. Revista de Direito Administrativo, Rio de Janeiro, Fundação Getulio Vargas, n. 32, p. 1-15, abr./jun. 1953.

PORTO NETO. Benedicto Pereira. Concessão de serviços públicos no regime da Lei $n$. 8.987/95: conceitos e princípios. São Paulo: Malheiros, 1998.

Licitação para contratação de parceria público-privada. In: SUNDFELD. Carlos Ari (Coord.). Parcerias público-privadas. São Paulo: Malheiros, 2005.

RIVERO, Jean. Droit administratif. 4. ed. Paris: Dalloz, 1970.

ROCHA, Cármen Lúcia Antunes. Estudo sobre concessão e permissão de serviço público no direito brasileiro. São Paulo: Saraiva, 1996.

ROSENVALD, Nelson. Código Civil comentado: doutrina e jurisprudência (comentário ao artigo 478). In: PELUSO, Cezar. (Org.). Código Civil comentado: doutrina e jurisprudência. 2. ed. São Paulo: Manole, 2008.

SALOMONI, Jorge Luis. Teoria general de los servicios públicos. Buenos Aires: Villela, 1999.

SILVA, José Afonso. Curso de direito constitucional positivo. 23. ed. São Paulo: Malheiros, 2003.

SOUTO, Marcos Jurema Vilella. Desestatização, privatização, concessão, terceirizações e regulação. 4. ed. Rio de Janeiro: Lumen Juris, 2001.

SUNDFELD, Carlos Ary. Direito administrativo econômico. São Paulo: Malheiros, 2000. Direito administrativo ordenador. 3. tiragem. São Paulo: Malheiros, 2003. . Fundamentos de direito público. 4. ed. 9. tiragem. São Paulo: Malheiros, 2008. .Guia jurídico das parcerias público-privadas. In: SUNDFELD, Carlos Ary (Coord.). Parcerias público-privadas. São Paulo: Malheiros, 2005. Projetos de lei de parcerias público-privadas: análise e sugestões. 2004 (mimeo). 
Serviços públicos e regulação estatal. Introdução às agências reguladoras. In: SUNDFELD, Carlos Ari (Coord.). Direito administrativo econômico. São Paulo: Malheiros, 2000.

WALD, Arnold; MORAES, Luiz Rangel de; WALD, Alexandre de M. $O$ direito de parceria e a nova Lei de Concessões. São Paulo: Revista dos Tribunais, 1996. 